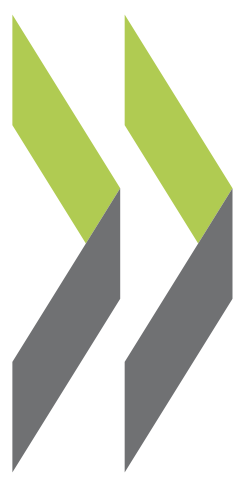

OECD Economics Department Working Papers No. 1362

Fostering Productivity for Income Convergence in the Czech Republic

\section{Falilou Fall,}

Christine Lewis 
Organisation de Coopération et de Développement Économiques

Organisation for Economic Co-operation and Development

21-Dec-2016

ECONOMICS DEPARTMENT

English - Or. English

FOSTERING PRODUCTIVITY FOR INCOME CONVERGENCE IN THE CZECH REPUBLIC

ECONOMICS DEPARTMENT WORKING PAPERS No. 1362

By Falilou Fall and Christine Lewis

OECD Working Papers should not be reported as representing the official views of the OECD or of its member countries. The opinions expressed and arguments employed are those of the author(s).

Authorised for publication by Alvaro Pereira, Director, Country Studies Branch, Economics Department.

All Economics Department Working Papers are available at www.oecd.org/eco/workingpapers

JT03407366

Complete document available on OLIS in its original format

This document and any map included herein are without prejudice to the status of or sovereignty over any territory, to the delimitation of international frontiers and boundaries and to the name of any territory, city or area. 
OECD Working Papers should not be reported as representing the official views of the OECD or of its member countries. The opinions expressed and arguments employed are those of the author(s).

Working Papers describe preliminary results or research in progress by the author(s) and are published to stimulate discussion on a broad range of issues on which the OECD works.

Comments on Working Papers are welcomed, and may be sent to OECD Economics Department, 2 rue André-Pascal, 75775 Paris Cedex 16, France, or by e-mail to eco.contact@oecd.org.

All Economics Department Working Papers are available at www.oecd.org/eco/workingpapers

This document and any map included herein are without prejudice to the status of or sovereignty over any territory, to the delimitation of international frontiers and boundaries and to the name of any territory, city or area.

The statistical data for Israel are supplied by and under the responsibility of the relevant Israeli authorities. The use of such data by the OECD is without prejudice to the status of the Golan Heights, East Jerusalem and Israeli settlements in the West Bank under the terms of international law.

Latvia was not an OECD Member at the time of preparation of this publication. Accordingly, Latvia does not appear in the list of OECD Members and is not included in the zone aggregates.

\section{(C) OECD (2016)}

You can copy, download or print OECD content for your own use, and you can include excerpts from OECD publications, databases and multimedia products in your own documents, presentations, blogs, websites and teaching materials, provided that suitable acknowledgment of OECD as source and copyright owner is given. All requests for commercial use and translation rights should be submitted to rights@oecd.org 


\section{ABSTRACT/RÉSUMÉ \\ Fostering productivity for income convergence in the Czech Republic}

Over the past two decades, the income level of the Czech Republic has converged considerably towards the OECD average. However, after the 2008 global crisis, the convergence process stalled. Shortfalls in labour productivity have developed and are mainly structural. Policies are needed to foster domestic sources of productivity growth. Better targeting of government R\&D support and more focused innovation policies that would be aided by a streamlining of policy institutions and interventions are necessary. In particular, tailored policies to increase knowledge-based capital (skills, management capacity, collaboration, etc.) are necessary to increase Czech firms' productivity. Also, resource reallocation should be facilitated by reforming framework conditions. In particular, bankruptcy rules, competition and regulation policies, access to finance and SME taxation need to be improved to boost SMEs' growth and productivity.

This Working Paper relates to the 2016 OECD Economic Survey of the Czech Republic (www.oecd.org/eco/surveys/economic-survey-czech-republic.htm).

JEL classification: J24, H25, O38, O47, O52

Keywords: Czech Republic, labour productivity, skill mismatch, R\&D tax incentives, Innovation, R\&D

$$
* * * * * * * *
$$

\section{Stimuler la productivité pour favoriser la convergence des revenus dans la République tchèque}

Au cours des deux dernières décennies, le niveau de revenu de la République tchèque s'est nettement rapproché de la moyenne de l'OCDE. Toutefois, après la crise mondiale de 2008, ce processus de convergence a marqué un coup d'arrêt. La productivité n'a pas progressé autant qu'attendu, principalement pour des raisons structurelles. Il est dès lors nécessaire de mettre en place des politiques publiques pour stimuler les sources internes de hausse de la productivité. Rationaliser les institutions chargées de l'élaboration de ces politiques aiderait à mieux cibler le soutien public à la $\mathrm{R} \mathrm{D}$ et à affiner les politiques de l'innovation. En particulier, des politiques spécifiquement conçues pour développer le capital intellectuel (compétences, capacité de direction, collaboration, etc.) s'imposent pour accroître la productivité des entreprises tchèques. Par ailleurs, il conviendrait de faciliter la réaffectation des ressources en réformant les conditions-cadres en vigueur. En particulier, les règles en matière de faillite, les politiques en matière de concurrence et de réglementation, l'accès aux financement et la fiscalité des PME doivent être améliorés pour accélérer la croissance des petites et moyennes entreprises et doper leur productivité.

Ce Document de travail se rapporte à l'Etude économique de l'OCDE de la République tchèque 2016 (www.oecd.org/fr/eco/etudes/etude-economique-republique-tcheque.htm).

Classification JEL : J24, H25, O38, O47, O52

Mots clefs : République tchèque, productivité, inadéquation des compétences, crédits d'impôt pour la recherche-développement, innovation, recherche-développement 


\section{TABLE OF CONTENTS}

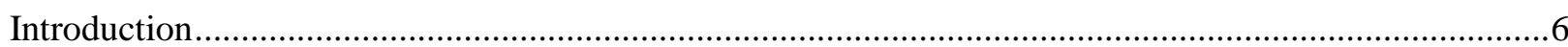

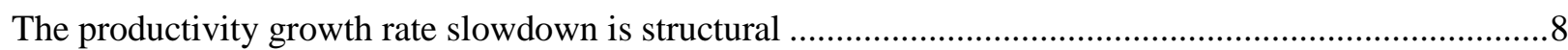

Labour productivity and total factor productivity growth rates have declined ...................................

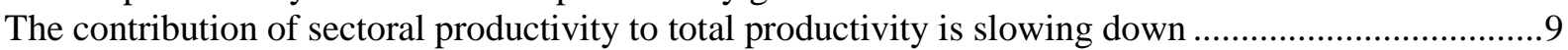

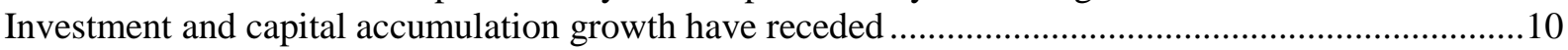

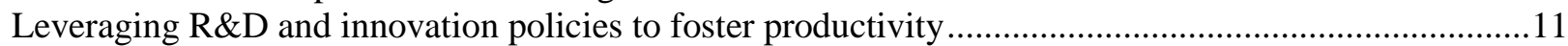

The R\&D and innovation performance are not yet satisfactory .........................................................

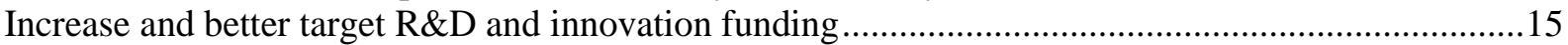

Streamline the administration and implementation of innovation policy ...........................................18

Upgrading the innovation system will increase productivity and competitiveness................................20

Appropriate framework conditions are needed to increase productivity ...............................................23

Removing obstacles for firm expansion and start-up creation will boost productivity ...........................23

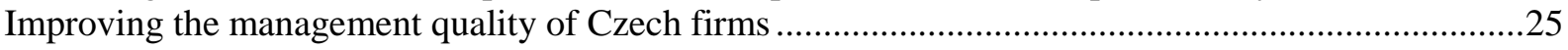

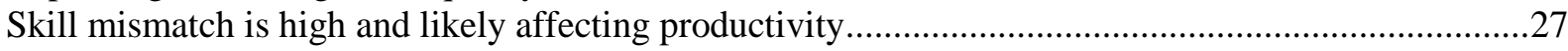

Raising competition and resource re-allocation to boost productivity ................................................. 31

Leveraging the high participation in global value chains to increase productivity ...................................37

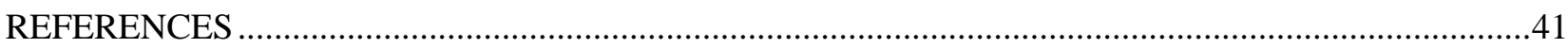

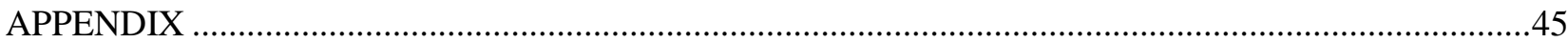

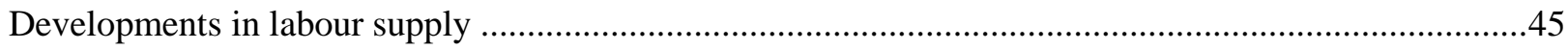

Investment and capital accumulation has receded since the crisis ..........................................................47

The contribution of sectoral productivity to the evolution of total productivity .......................................49

\section{Tables}

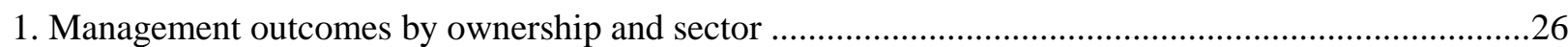

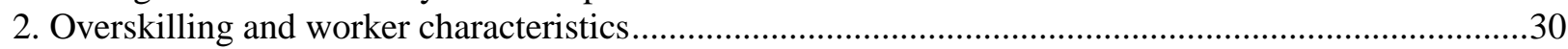

\section{Figures}

1. GDP per capita

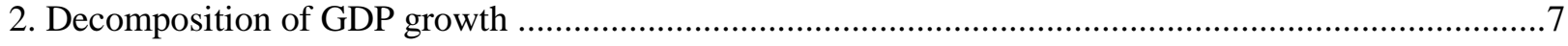

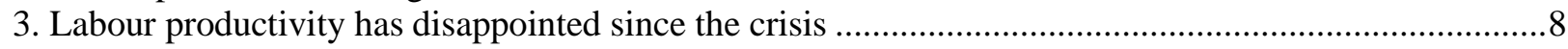

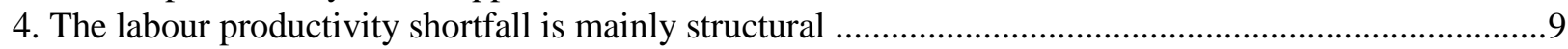

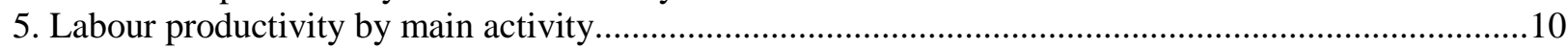

6. Capital accumulation has been undermined by the crisis ..................................................................11

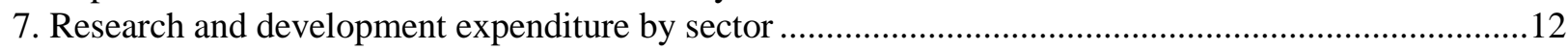

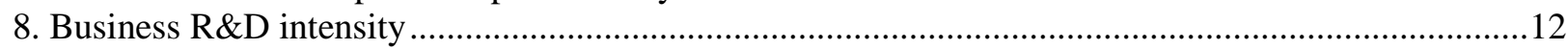

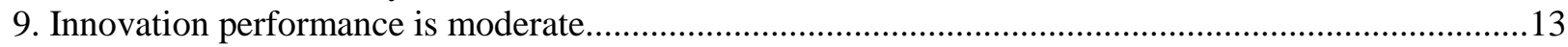


10. Innovation is moderate in manufacturing and services sectors......................................................14

11. Innovation results are not in line with spending: illustration from the ICT sector ...........................15

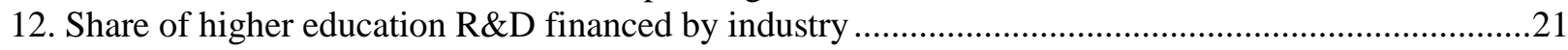

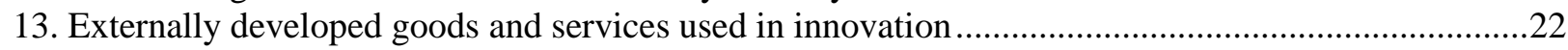

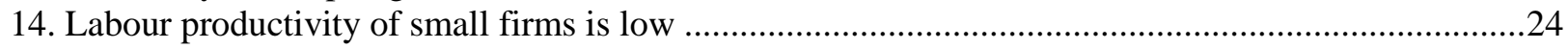

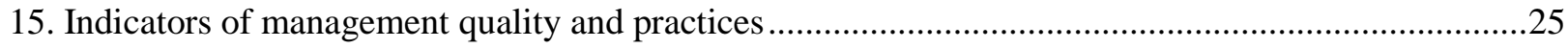

16. There is a large difference in managerial quality by firm size ..........................................................26

17. A relatively high share of Czech workers are over-skilled ............................................................27

18. Estimated labour productivity gains from moving policy-related factors to best practice ...................29

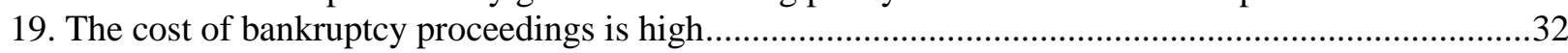

20. Consumer market scoreboard: Czech Republic versus EU average .................................................32

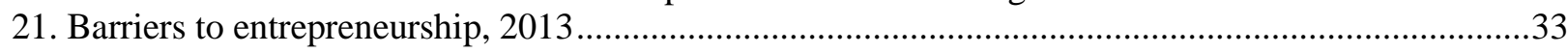

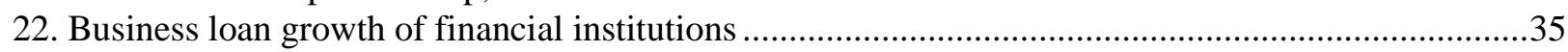

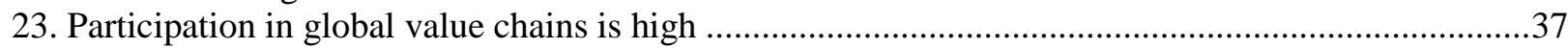

24. Intermediate inputs in key manufacturing sectors ...........................................................................39

25. Services outsourcing and labour productivity growth in the manufacturing sector............................40

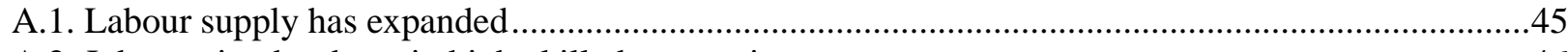

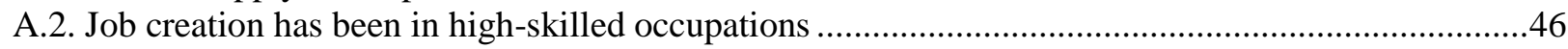

A.3. Self-employment is high compared to other OECD countries.......................................................47

A.4. Capital intensity in the Czech Republic is mixed ........................................................................48

A.5. The importance of services has been rising in the Czech Republic ..................................................49

A.6. Change in average labour productivity growth by sector ..........................................................50

A.7. Productivity gains within each sector have driven aggregate labour productivity growth .................51

\section{Boxes}

Box 1. Technology Agency of the Czech Republic ...............................................................................16

Box 2. Czech innovation policies and bodies: a complex organisational structure …..............................19

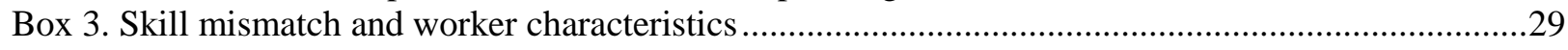

Box 4. The Czech-Moravian Guarantee and Development Bank .............................................................34

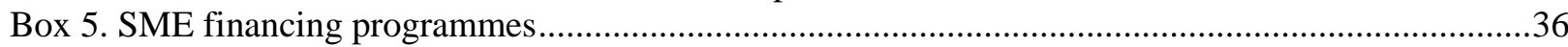

Recommendations to foster productivity growth and income convergence …........................................40 


\title{
FOSTERING PRODUCTIVITY FOR INCOME CONVERGENCE IN THE CZECH REPUBLIC
}

\author{
By Falilou Fall and Christine Lewis ${ }^{1}$
}

\section{Introduction}

1. Over the past two decades, the income level of the Czech Republic has converged towards the OECD average. Between 1995 and 2013, GDP per capita rose by 48\%, reaching 76\% of the OECD average level in 2014. Productivity catch-up was critical, aided by better integration into the global economy. However, since the 2008 global crisis, the convergence process has stalled. While other countries in Central and Eastern Europe (CEE), in particular Estonia, Slovakia and Poland (Figure 1, Panel A), continued to converge, Czech GDP per capita has lingered around its 2008 level (Figure 1, Panel B). Moreover, in comparison with either CEE countries or "small" advanced European countries, labour productivity in the Czech Republic has a similar lacklustre performance as GDP per capita (Figure 1, Panel C and D). The growth rate of labour productivity fell from $4.3 \%$ in the period 200107 to $0.4 \%$ in the period $2007-14$.

2. Gains in total factor productivity and capital accumulation had been the main drivers of Czech economic growth in the pre-crisis period (Figure 2) and the slowdown in both have contributed to the flat profile of output since the beginning of the crisis, especially total factor productivity.

Figure 1. GDP per capita and labour productivity

A. GDP per capita

Constant prices, thousand USD PPP
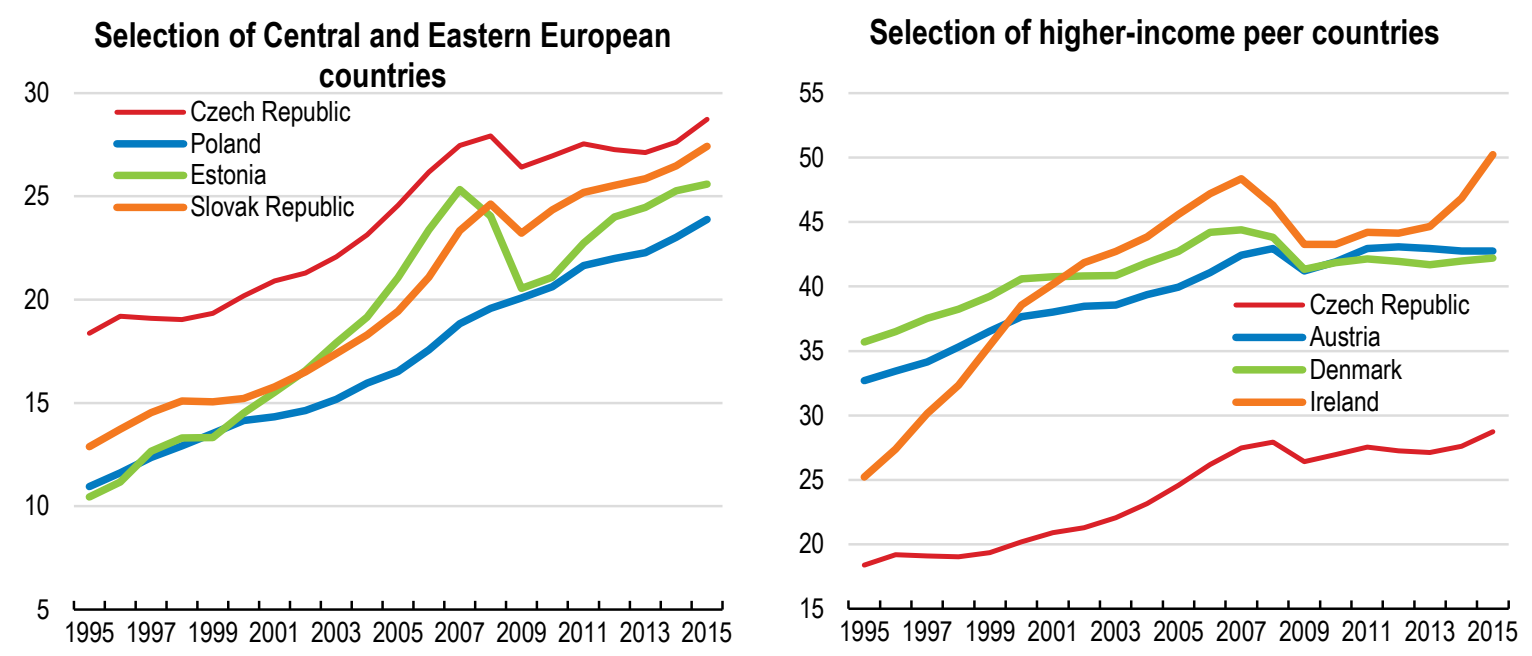

1. Falilou Fall is a Senior Economist and Christine Lewis is an Economist in the Country Studies Branch of the OECD Economics Department. They are grateful to numerous colleagues for valuable comments and discussions, including: Andreas Wörgötter, Robert Ford, Alvaro Pereira, Peter Hoeller, Claude Giorno, Müge Adalet McGowan and Dan Andrews (Economics Department); Bert Brys (Centre for Tax Policy and Administration); and Dirk Pilat (Directorate for Science, Technology and Innovation). The paper also benefitted from comments from the Czech authorities. The authors are also grateful to Martin Hronza and Zdenek Pikhart (Czech Ministry of Industry and Trade and Ministry of Finance, respectively) for their help during their secondments to the OECD, to Béatrice Guerard, Guillaume Bousquet and Patrizio Sicari (Economics Department) for excellent statistical support and Heloise Wickramanayake (Economics Department) for valuable secretarial assistance. 


\section{B. Labour productivity}

Constant prices, USD PPP
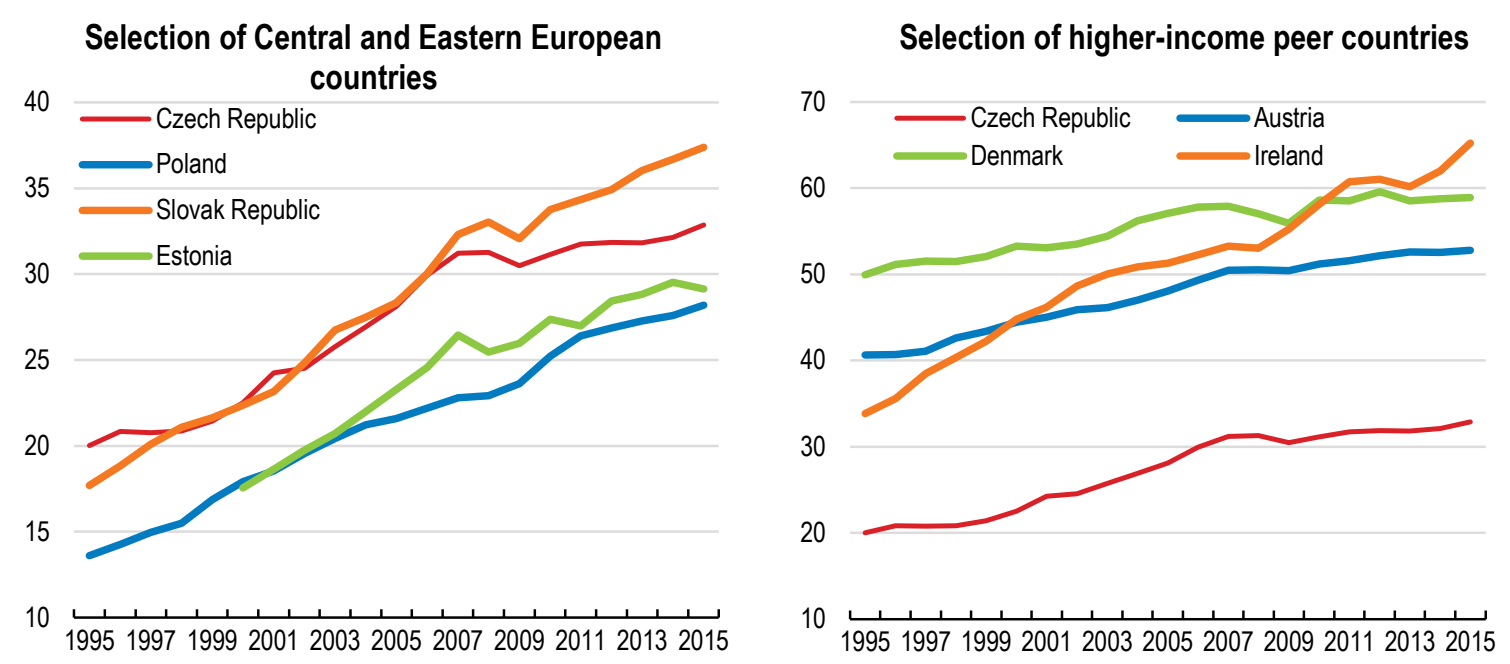

Source: OECD Productivity database; OECD calculations.

Figure 2. Decomposition of GDP growth

Percentage points

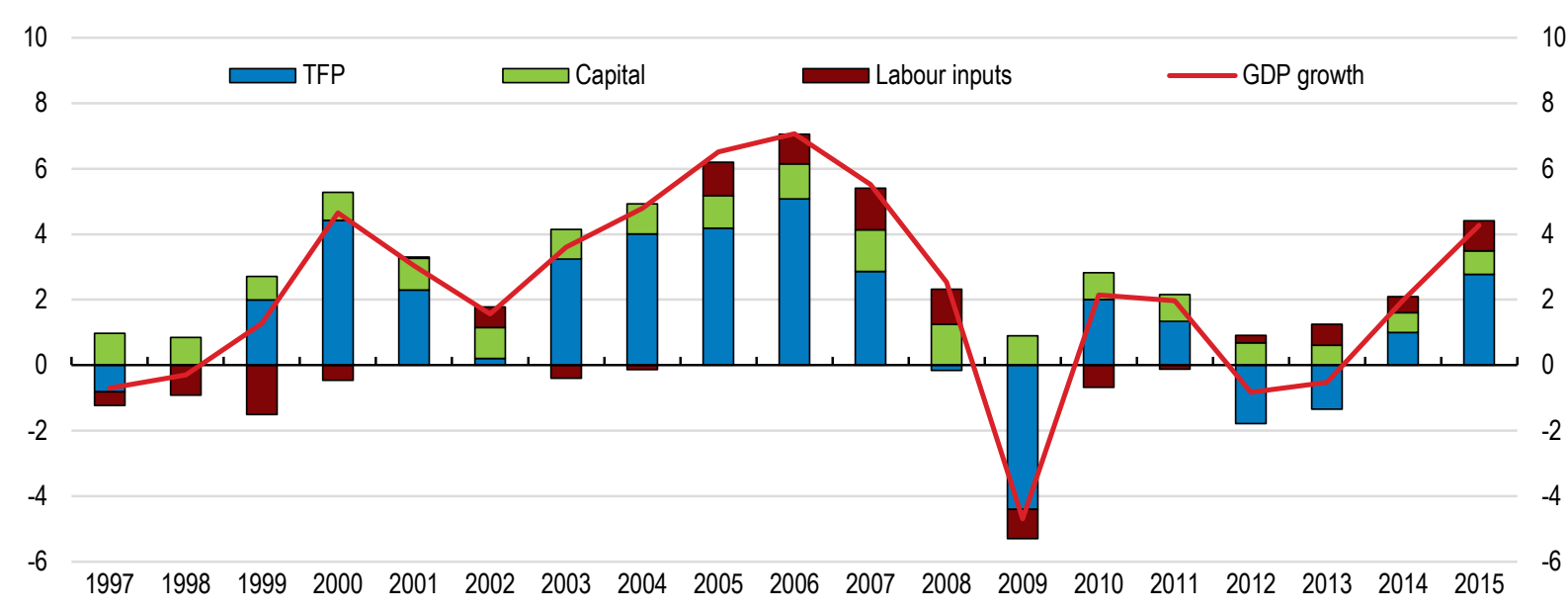

Source: OECD Economic Outlook database; OECD calculations.

3. In the first section of this paper, productivity developments are decomposed and analysed. In particular, the impacts of labour productivity's evolution, the dynamic of capital accumulation and the effects of productivity at the sectoral level on aggregate productivity are disentangled. The second section focuses on R\&D and innovation policies to foster productivity growth. In the third section, the different policies to improve the market framework conditions for productivity and, therefore, businesses' growth are analysed. 


\section{The productivity growth rate slowdown is structural}

\section{Labour productivity and total factor productivity growth rates have declined}

4. Labour productivity trends show a clear structural break in 2008 at the beginning of the crisis (Figure 3, Panel A). With respect to the pre-crisis trend, a large labour productivity shortfall has emerged, amounting to 21\% (Figure 3, Panel B). Figure 3, Panel C confirms that the post-crisis development is abnormally flat, pointing to a trend change in production processes since the crisis. Compared with earlier periods of very slow or negative growth, the economy has not been able to recapture the same dynamism after the 2008-09 recession. However, the gap is not growing anymore. Figure 3, Panel D shows that total factor productivity has slowed down.

5. The increase in employment occurred in a context of an expanding labour supply. Since 2009, the working-age population has been decreasing, partly due to ageing and declining inward migration. However, participation has increased markedly, in particular among individuals aged between 50 and 64 , offsetting demographic shifts (see Appendix).

Figure 3. Labour productivity has disappointed since the crisis ${ }^{1}$
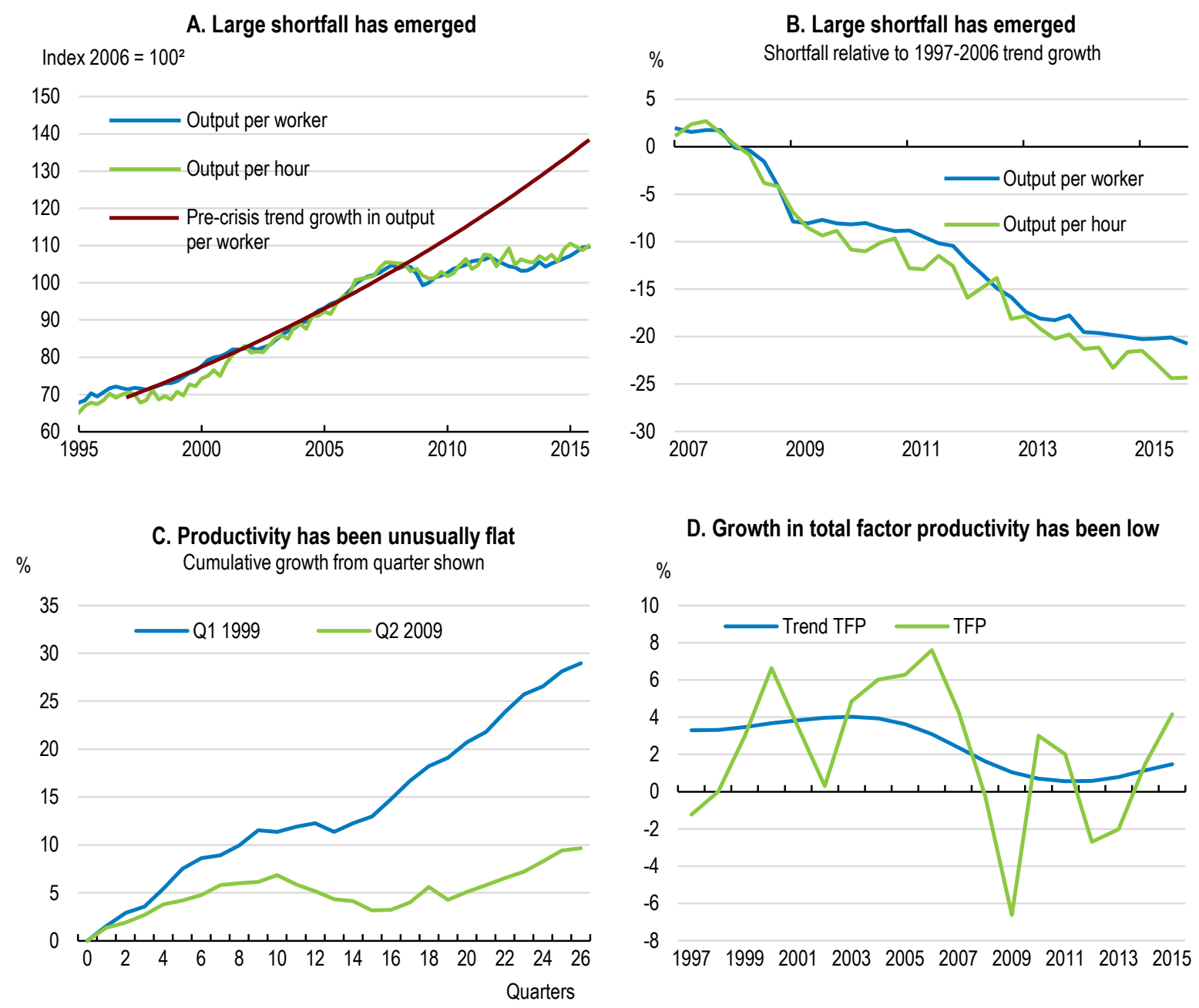

\section{Growth in total factor productivity has been low}

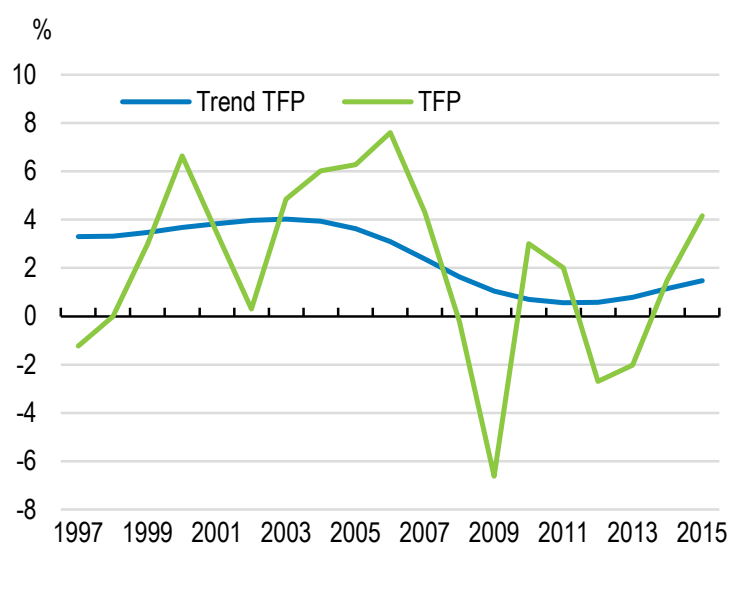

1. Output refers to real gross value added.

2. Pre-crisis trend growth in output per worker is calculated from a linear trend between 1997 and 2007, and is projected from 2008 onwards.

Source: Calculations based on data from OECD Quarterly National Accounts database and OECD Economic Outlook database 
6. However, relying on productivity levels may obscure productivity trends. The evolution of the productivity level could be affected by positive and negative cyclical developments. Using potential productivity helps to disentangle short-run and long run developments, although estimates of potential productivity as of potential GDP could be subject to frequent revisions (Ollivaud and Turner, 2014). At $16 \%$, the Czech Republic exhibits one of the highest potential labour productivity shortfalls, while the productivity shortfall is $21 \%$ (Figure 4). While cyclical developments are at play, the productivity shortfall seems to be thus largely structural, pointing to a need for structural reforms to boost productivity growth.

Figure 4. The labour productivity shortfall is mainly structural

Deviation from pre-crisis trend growth, Q4 2015
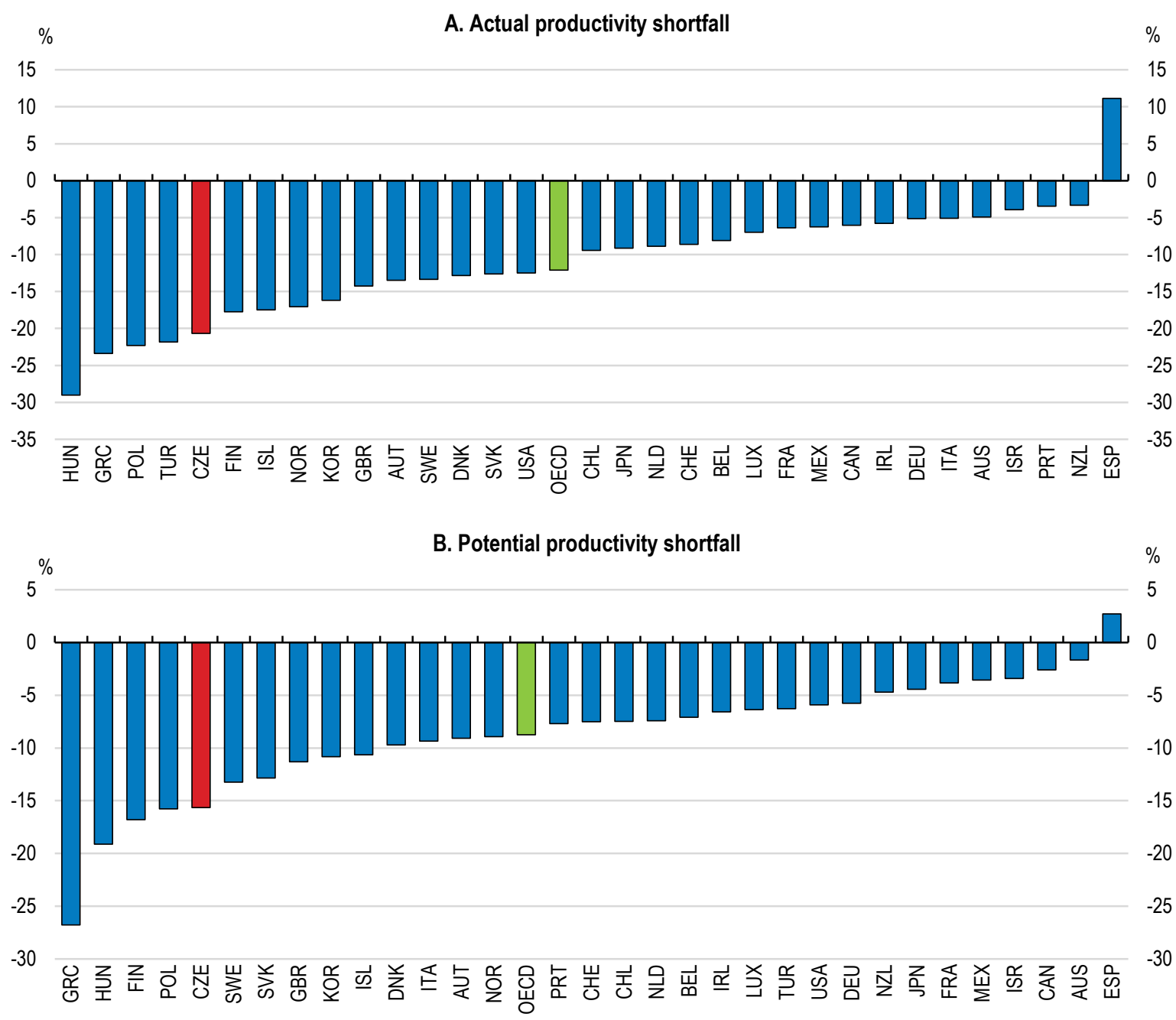

Source: Calculations based on data from OECD Economic Outlook database.

\section{The contribution of sectoral productivity to total productivity is slowing down}

7. The shift in the composition of the economy, in particular from services (non-financial) to manufacturing, has accelerated since the crisis, with manufacturing representing $25 \%$ of total value added in 2014 compared to $18.1 \%$ in 2004 . Labour productivity growth in the manufacturing sector has decreased since the crisis but remains positive, while it is close to zero in the service sector. Further decomposition of 
labour productivity by activity shows that labour productivity growth fell in all sectors except for financial and insurance activities in the period 2007-14 compared with 2001-07, with manufacturing displaying an important decrease (Figure 5 and Figure A.6).

8. A shift-share analysis shows that the sectoral reallocation of resources, in particular of employment, plays only a small role in productivity developments. The main driver of aggregate productivity growth is within-sector labour reallocation (see Appendix, Figure A.6).

\section{Figure 5. Labour productivity by main activity}

Real value added per hour worked, average annual rate of change

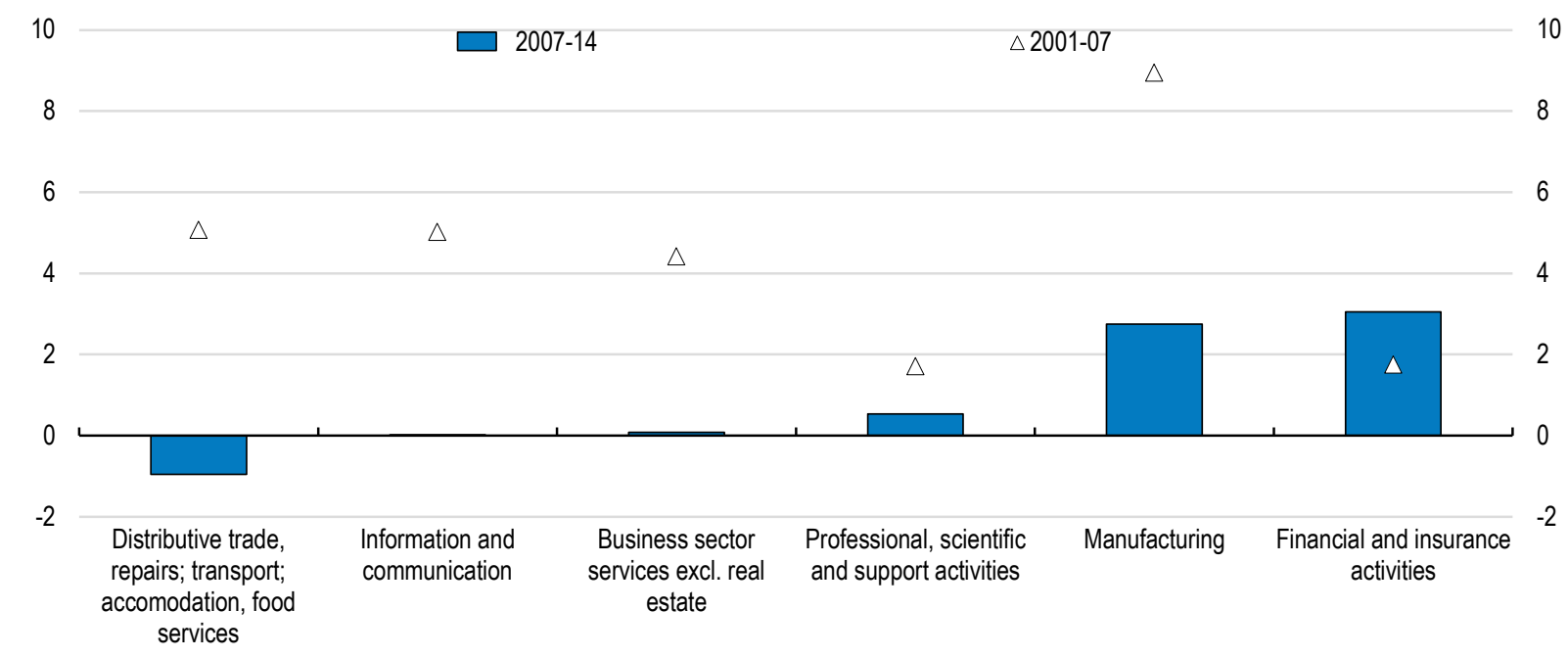

Note: Business sector services covers: distributive trade and repairs; transport, accommodation and food services; information and communication; financial and insurance activities; and professional, scientific and support activities.

Source: OECD Productivity Database, April 2016.

\section{Investment and capital accumulation growth have receded}

9. The lacklustre economic performance is partly explained by business investment and capital accumulation, which have lost steam since the start of the crisis. The slower capital stock accumulation is explained partly by a decline in the investment rate (Figure 6). However, the Czech investment rate remains among the highest in the OECD but the rate of depreciation is also high (see Appendix, Figure A.4). Intangible investment has shown a stronger dynamic since the crisis, though from a low level and is only at the OECD average (see Appendix, Figure A.4). The lower growth rate of capital stock since the crisis led to lower capital intensity which contributed to lower labour productivity growth. 
Figure 6. Capital accumulation has been undermined by the crisis
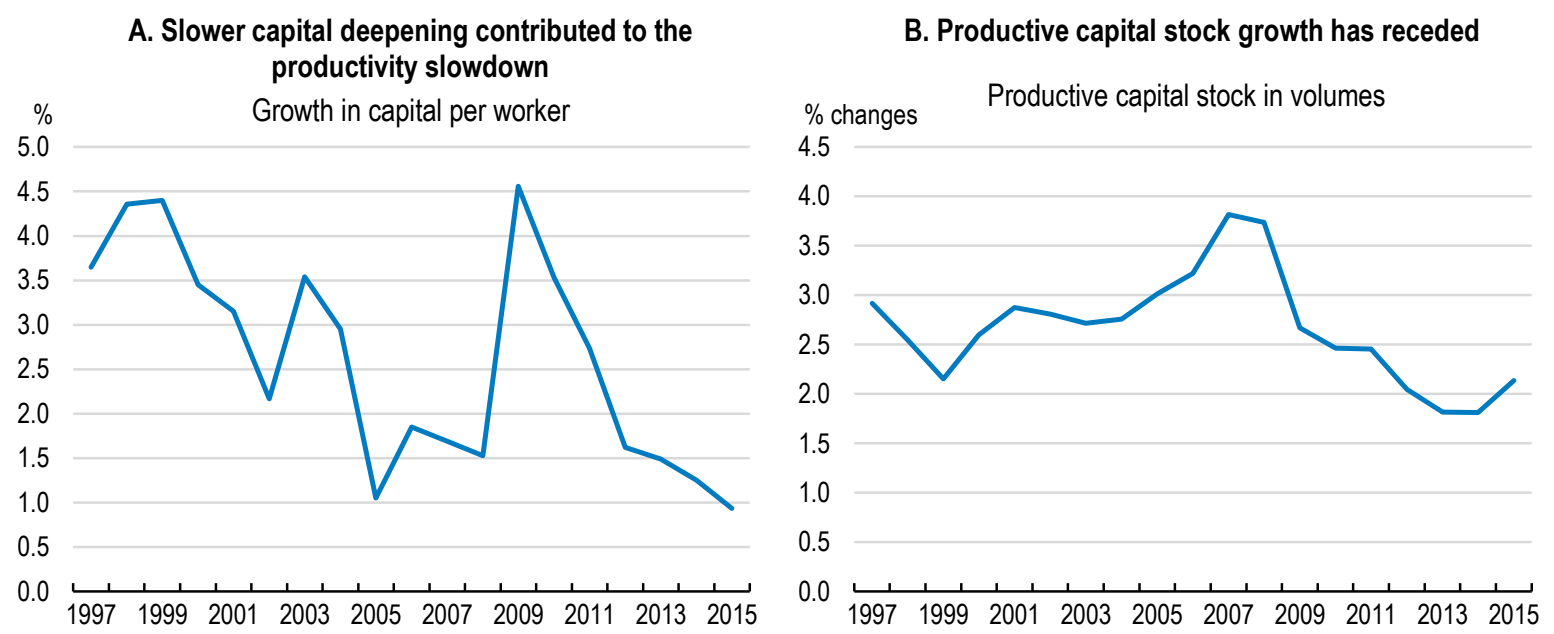

Source: OECD Economic Outlook database.

\section{Leveraging R\&D and innovation policies to foster productivity}

10. Until 2008, country-level characteristics contributed the most toward explaining productivity growth in catching-up countries, such as the Czech Republic (Dall'Olio et al., 2014). More precisely, since independence, inward foreign direct investment, international linkages of firms and credit availability have had a significant impact on productivity growth. As the Czech economy is already one of the most integrated in the global value chain (Figure 23), reviving the productivity catching-up process has to be domestically-driven. In particular, there is a need to boost the productivity of Czech firms not affiliated to foreign firms and to facilitate the expansion of SMEs and the creation of new firms. Moreover, improving infrastructure is essential to create a productive environment for firms.

\section{The $R \& D$ and innovation performance are not yet satisfactory}

11. R\&D spending has been increasing since 2003 and amounted to almost $2 \%$ of GDP in 2014 . Czech R\&D spending is evenly distributed among basic research, applied research and experimental development. Business enterprise research and development (BERD) represents the biggest share of R\&D spending, but a non-negligible part (40\%) is coming from government spending (Figure 7). BERD is mainly initiated by firms that are foreign-owned or affiliated to foreign enterprises $(56 \%$ of BERD in 2014). 
Figure 7. Research and development expenditure by sector

$\%$ of GDP, 2014

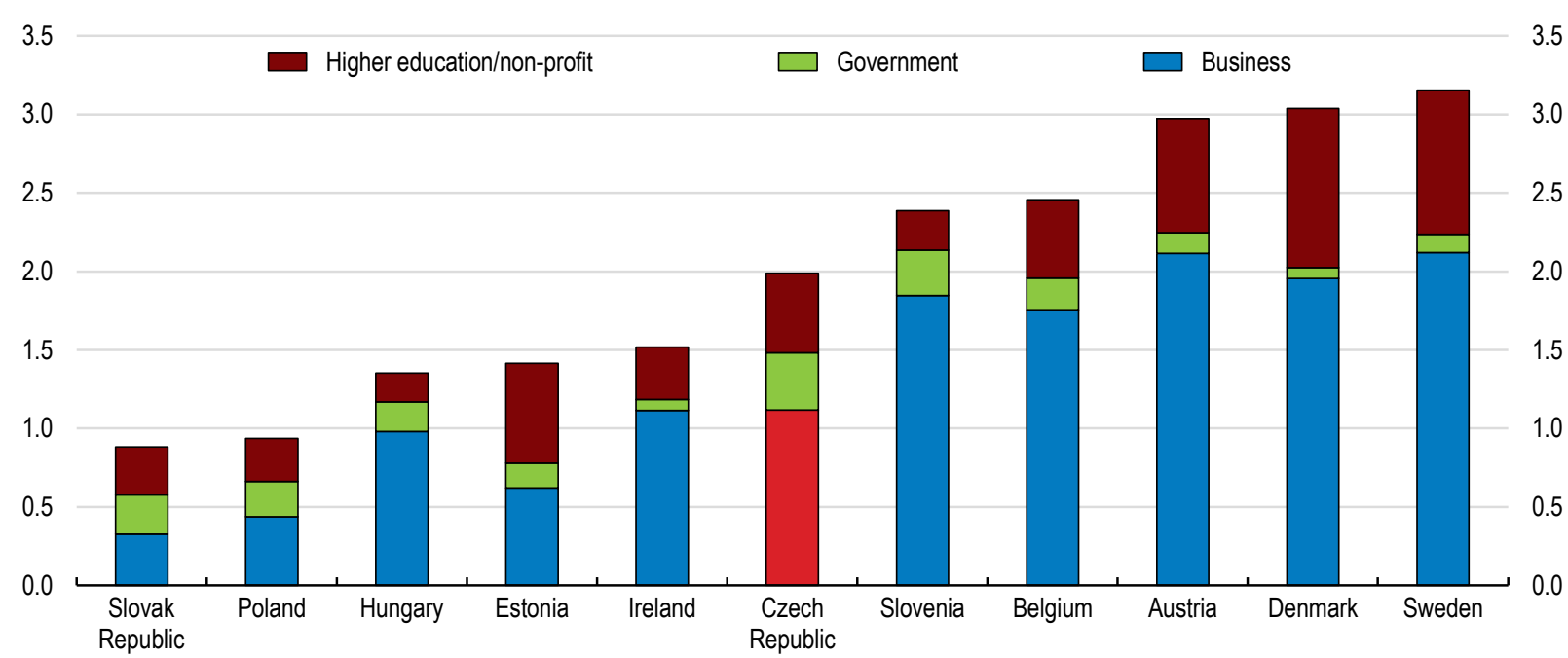

Source: OECD (2016), Main Science and Technology Indicators database.

12. Overall, the $R \& D$ intensity remains relatively modest for a country with such a large manufacturing sector (Figure 8). One of the reasons is that Czech firms affiliated to foreign companies, in particular in manufacturing, tend to be concentrated in the low value-added segments of global value chains with low R\&D. Indeed, cross-border investment in Czech manufacturing generates jobs for lowskilled workers and deepens the specialisation in the low-technological segments with little room for upgrading (Münich et al., 2014).

Figure 8. Business R\&D intensity

2014 or latest available, as a percentage of value added in industry

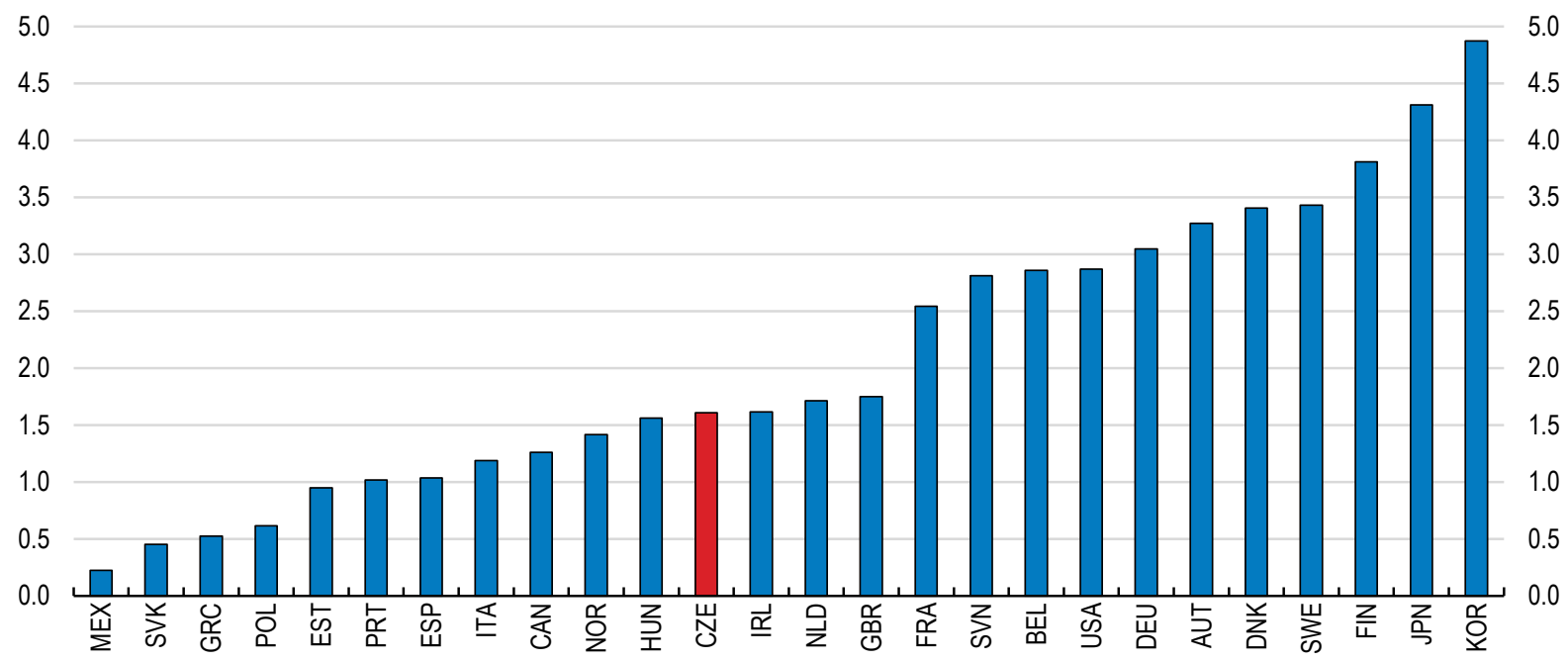

Note: Business R\&D intensity is calculated as business $R \& D$ expenditure relative to value added.

Source: OECD (2016), Main Science and Technology Indicators database. 
13. Despite a sustained effort in the past ten years to increase research, development and innovation (RDI) spending, the innovation performance of the Czech Republic remains mixed. In the European Union's classification of country performances in terms of innovation, the Czech Republic is among the group of moderate innovators (Figure 9). There has been noticeable progress in some dimensions of the innovation environment such as increases in higher education, in particular the number of doctorate graduates and people with tertiary degrees.

Figure 9. Innovation performance is moderate

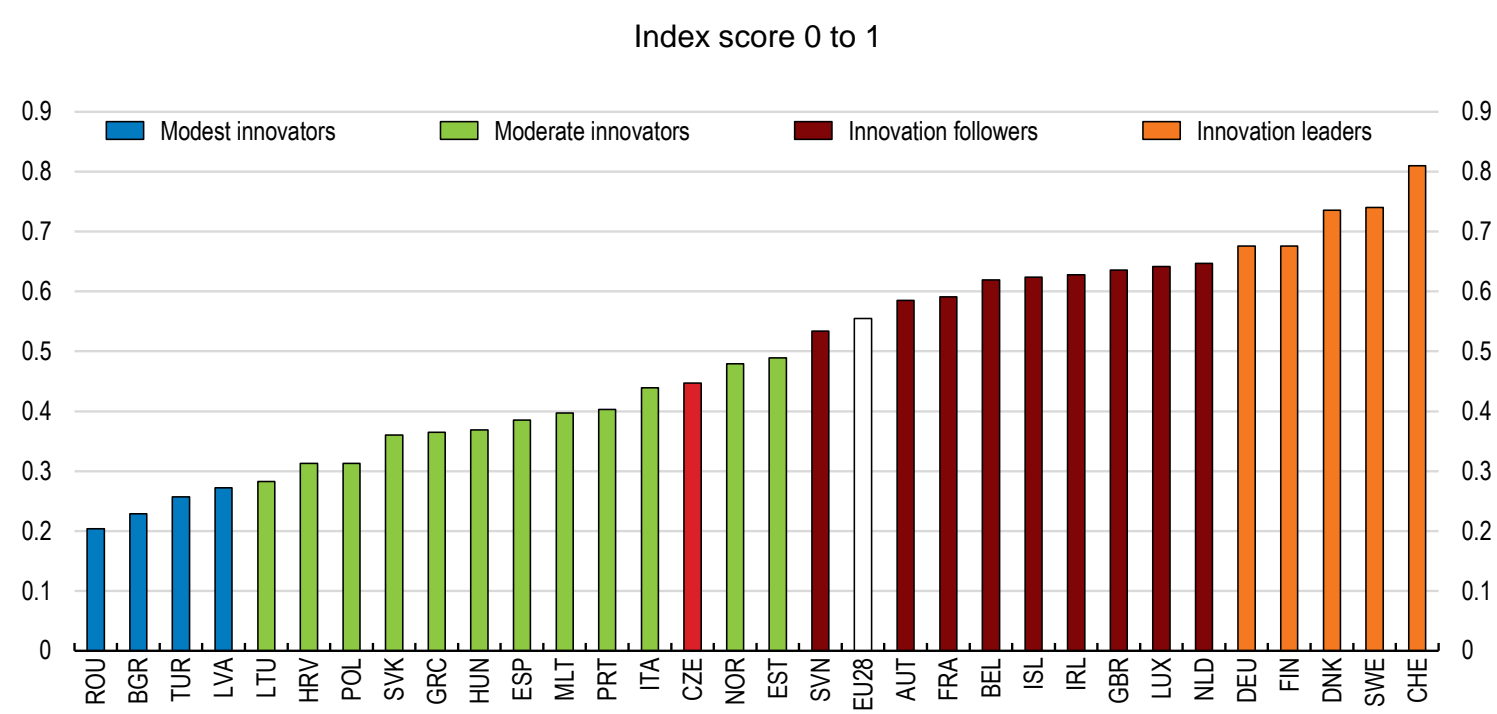

Note: Average performance is measured using a composite indicator building on data for 25 indicators going from a lowest possible performance of 0 to a maximum possible performance of 1 . Average performance reflects performance in 2012 due to a lag in data availability.

Source: European Commission, Innovation Union Scoreboard 2015.

14. Modest performance in innovation is also apparent in small and medium-sized enterprises (SMEs). SMEs account for the vast majority of Czech firms, but few are innovators (OECD, 2015a). Furthermore, the manufacturing sector, which is important in the economy, has a moderate innovation performance (Figure 10, Panel A). In particular, product and process innovation is relatively low. The service sector, which plays an important role as provider of inputs for the manufacturing sector, has a weak performance indicator. Figure 10, Panel B shows that only around 10\% of firms in the service sector introduce new products in the market. 
Figure 10. Innovation is moderate in manufacturing and services sectors
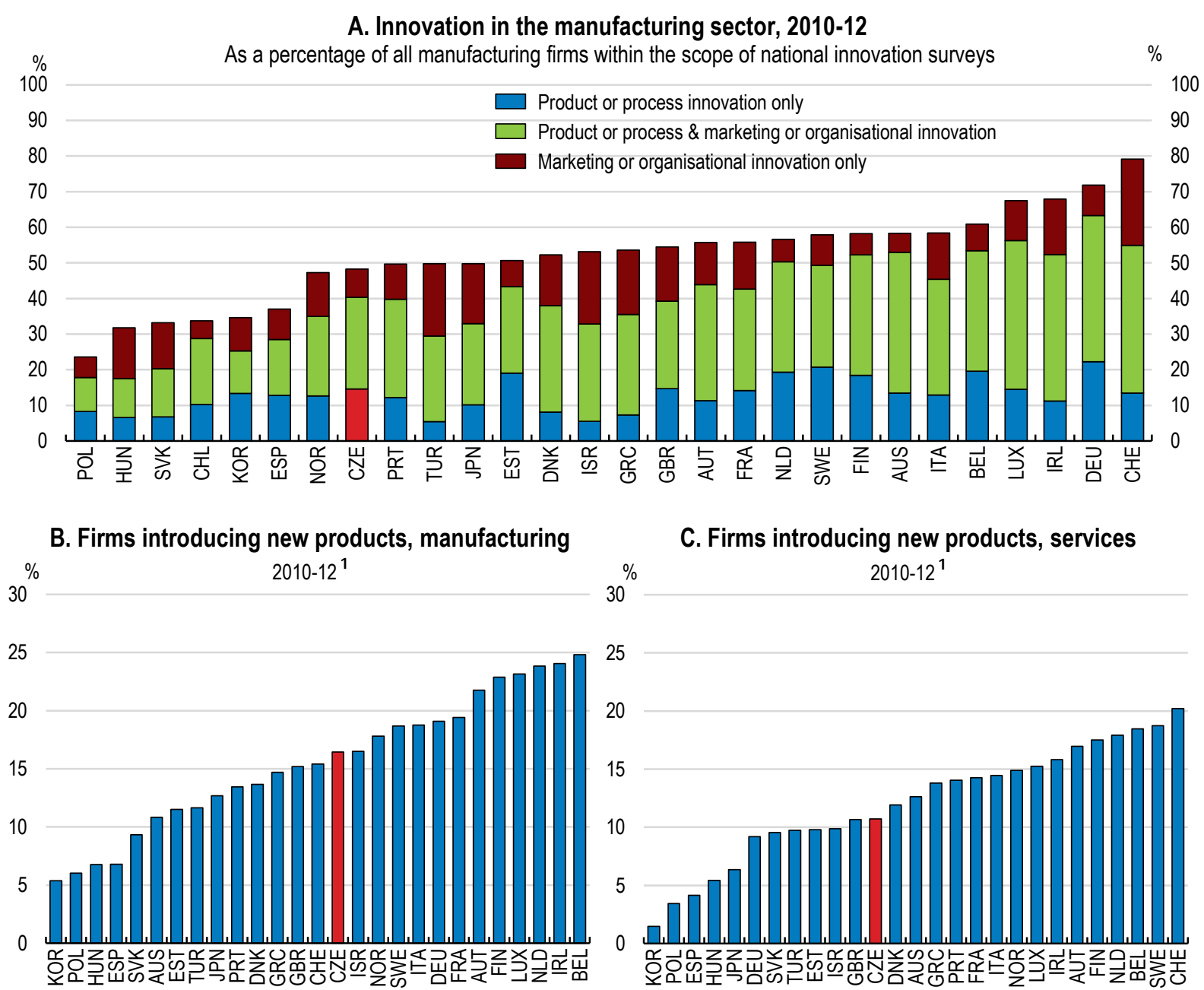

\section{Firms introducing new products, services} $30^{\%}$ $2010-12^{1}$

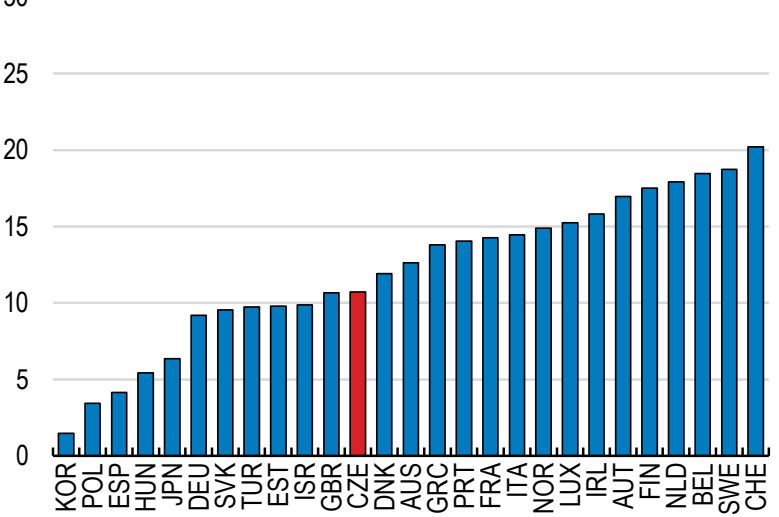

1. As a percentage of all firms in each sector within the scope of national innovation surveys.

Source: OECD (2015), OECD Science, Technology and Industry Scoreboard 2015: Innovation for growth and society, OECD Publishing, Paris. http://dx.doi.org/10.1787/sti_scoreboard-2015-en.

15. This mismatch between RDI spending and innovation performance is also illustrated by the ICT sector. In Figure 11 (Panel A), Czech firms are among those that devote one of the highest share of their equipment investment to ICT components, while they rank among the moderate innovative enterprises (Figure 11, Panel B). Therefore, it is not only the level of RDI spending which explains the moderate innovation performance but also the enabling environment (resource reallocation and framework conditions) and the complementary investments (in skills, organisational change, process innovation, management etc.). 
Figure 11. Innovation results are not in line with spending: illustration from the ICT sector

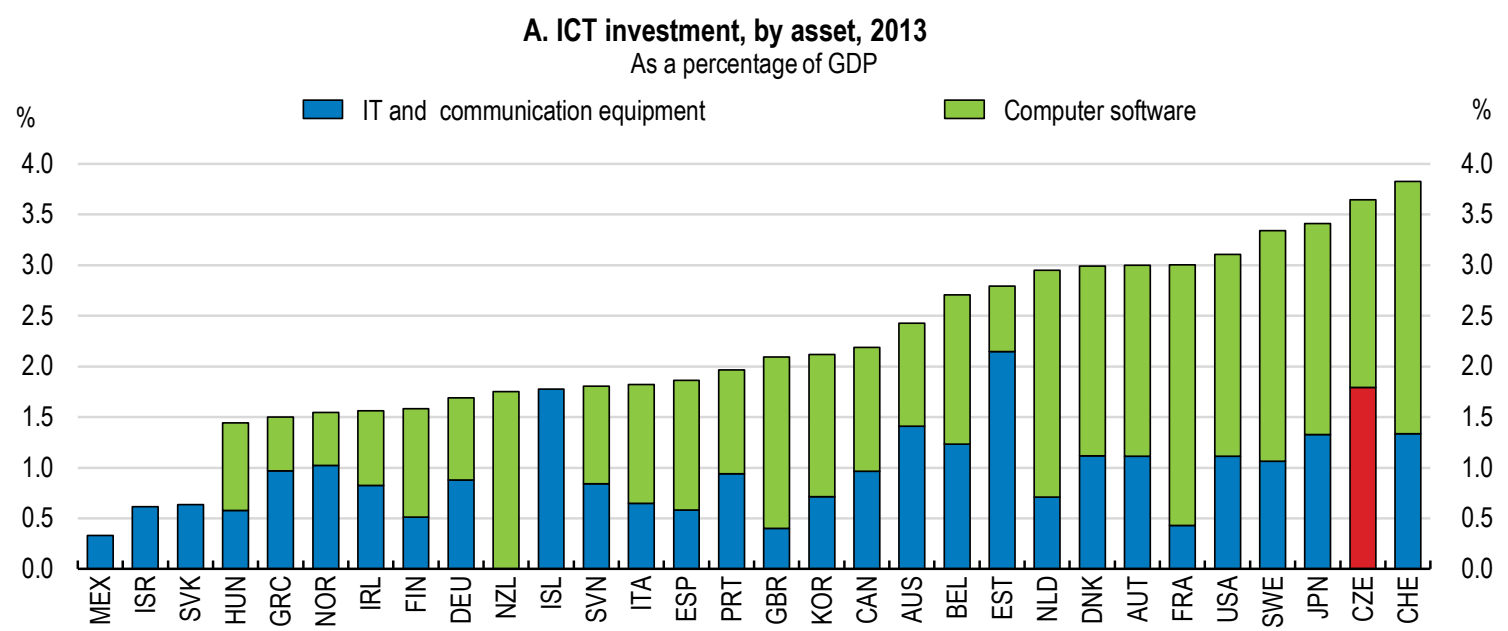

B. Number of ICT-related patents, 2010-13

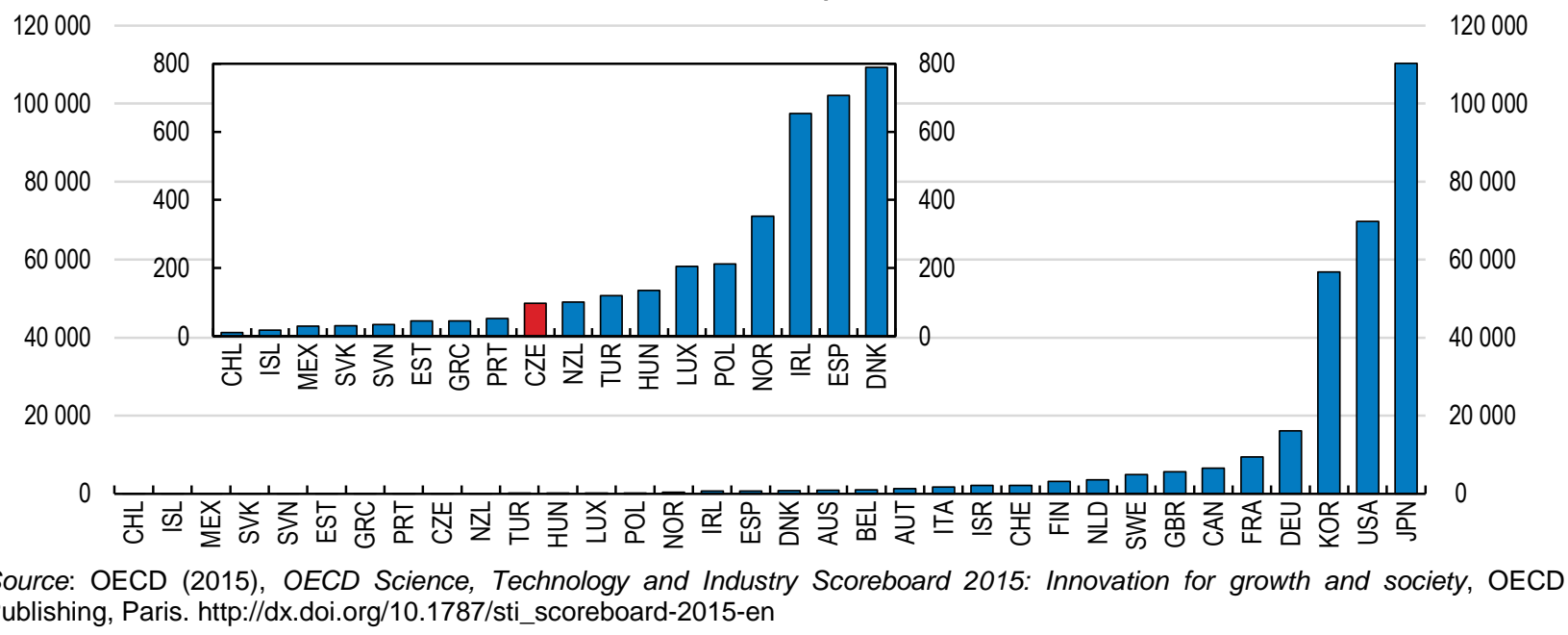

\section{Increase and better target $R \& D$ and innovation funding}

\section{Better targeting $R \& D$ spending}

16. In the last ten years Czech spending on R\&D has increased steadily from $1.1 \%$ of GDP in 2003 to $2 \%$ of GDP in 2014 (OECD, 2015a). That level is still below the OECD average (2.4\% of GDP) but is a significant effort towards setting up a well-performing innovation system. The increase in RDI spending should be continued as it is a key element for the upgrading of the economy in global value chains. Government $R \& D$ spending is focused on basic research and higher education institutions, but a nonnegligible part of government $R \& D$ spending is directed to support BERD undertaken in SMEs, representing $64 \%$ of R\&D spending of SMEs. Large firms, in particular those with foreign affiliations, run their R\&D more independently.

17. Different measures could be considered to increase and better target government funding of RDI. One reason business RDI spending is low in comparison with the leading innovative countries (Figure 7) is that because most of the important Czech firms are foreign owned or affiliated, they do not decide their RDI initiatives. However, that does not seem to be the only reason, as $58 \%$ of business R\&D was incurred 
by foreign-controlled affiliates in 2011 (OECD, 2015a). There is also a lack of investment in RDI by national firms. The government has put in place programmes to encourage greater business RDI spending by intensifying collaboration between businesses and research institutions. These programmes are financed by EU funds as well as from national resources (the new high-tech R\&D support programme TRIO and by the Technology Agency). However, direct government funding of business RDI is moderate, representing $0.1 \%$ of GDP in 2013. Under these programmes, more co-financing should be developed to incentivise firms to mobilise their own resources.

18. Government R\&D spending should better incentivise Czech firms, which seem to invest less in $R \& D$ than foreign-affiliated firms. That would broaden the scope of R\&D activities undertaken in the country. Important steps have been made recently to reinforce innovation policy. The RDI enabling environment has been boosted with infrastructure programmes and the creation of competence centres. Using EU funds, 8 centres of excellence and 40 regional centres of $R \& D$ have been founded or extended (investment in infrastructure), mostly specialised in specific topics (biotechnology, biomedicine or sustainable energetics, etc.) and inside universities, technology institutes and the Academy of Science. The competence centres supported by the Technology Agency of the Czech Republic (Box 1) are more focused on the development of soft knowledge and human resources.

19. The conversion of research into innovation in goods, services and processes could be improved by increasing the collaboration between research institutions and enterprises. Programmes run by the Technology Agency should be reinforced to bolster the transformation of research developed in public entities into marketable goods and services. For instance, mixed public-private entities could be set up closely related to the different research institutions in charge of scrutinising the different research results and developing further those that have a potential market.

20. The development of the evaluation framework of R\&D support should be accelerated. An important part of $R \& D$ and innovation financing is based on grants for projects. The government is planning to introduce a global evaluation framework, including improvements in the information system, to assess research outputs and more general benefits. The point system of evaluation used for the allocation of R\&D support to research institutions is largely criticised. It gives biased incentives for short-run research and strategies to earn points at the expense of long-run and more promising research. Core research institutions' financing should be more secure and its renewal subject to evaluations at reasonable intervals and grant financing of research used to direct or support research on national priorities. A comprehensive evaluation framework is crucial for better orienting research funding towards general purpose technologies and also allows funding to be reallocated to new projects or objectives easily (Rodrik, 2008).

\section{Box 1. Technology Agency of the Czech Republic}

The Technology Agency of the Czech Republic (TACR) is part of the state system of support for applied RDI. TACR was established in 2009 under the Act on Support for Research, Experimental Development and Innovations. TACR is in charge of implementing innovation policies, by providing targeted support to projects on applied research that contribute to increasing competitiveness and economic growth.

TACR is a separate entity that independently manages resources allocated by the state budget. In 2014 the approved budget was CZK 2.96 billion and in 2015 CZK 2.86 billion of which targeted support represents $97 \%$ and $96 \%$ respectively. Its support is carried out under different programmes:

- $\quad$ The Alpha Programme aims to support applied research and experimental development in the field of advanced technology, environment and energy and transport. It is the largest program of TACR.

- $\quad$ The Beta Programme aims to support RDI designed for the needs of public authorities. The programme is implemented by entering a single procurement in research and development based on the requirements of relevant government authorities. 
- The Competence Centres Programme focuses on long-term projects (up to eight years) and the establishment of centres of research development and innovation in advanced fields. The program supports the creation of strategic partnerships between enterprises and research organisations. The emphasis is also placed on motivating young early-stage researchers.

- The Omega programme aims to strengthen research activities in the field of applied social sciences. The specific objectives of the programme include improving the efficiency of public policies, implementing and promoting the interests of the Czech Republic, and development of regions in the context of the European integration process, among other areas.

- The Gamma programme aims to support the verification of the results of applied research and experimental development in terms of their practical application, and to prepare their subsequent commercial exploitation.

- $\quad$ The Delta Programme aims to promote co-operation in applied research and experimental development through joint projects of international technology and innovation agencies or other similar institutions and research organizations supported by the TACR.

- The Programme Epsilon has a particular focus on improving the position of the Czech industry by supporting projects of applied research and experimental development, the results of which have high potential for rapid application in new products, production processes and services, particularly in the following priority areas: a competitive knowledge economy; sustainability of energy and material resources; environment for a good life.

In 2014, 229 projects in programmes Alpha and Omega were completed. Most of them lasted for 3-4 years. Most of the projects were realized in Prague and South Moravia, and from a sectoral perspective in manufacturing.

\section{Targeted fiscal incentives for innovation}

21. Well designed and properly administered tax incentives for RDI can complement grants funding. Government support for business R\&D through tax incentives increased by 12.2 percentage points between 2006 and 2013, to 32\% of government R\&D spending (OECD, 2015a). European innovation leaders tend to have a higher share of tax incentives in their R\&D spending (Denmark, 53.8\%; Netherlands, 87.4\%; the United Kingdom, 48.3\%). Also, tax incentives are more neutral, except for firm size, and less governmentguided than grants as firms mobilise their own resources toward their own projects before claiming the tax reduction.

22. However, tax incentives may favour incumbents at the expense of young firms. Indeed, the implicit subsidy rate of tax incentives is related to firm profitability and young firms and SMEs are often in a loss-making position in the early years of an R\&D project (Adalet McGowan et al., 2015). The effect may be particularly hampering for productivity growth, as young firms are often very entrepreneurial and innovative in countries with well-performing innovation systems. Furthermore, it is important to guarantee that $R \& D$ tax incentives are refundable or contain carryover provisions so as to avoid overly favouring less dynamic incumbents at the expense of dynamic young firms (OECD, 2015b). Therefore, a balance should be maintained between different types of government funding through grants, loans, co-financing, loan guarantees and tax provisions. In any case, the uncertainties about receiving tax deductions related to RDI spending should be reduced through a simplified and more transparent claiming system. To ensure that R\&D tax credit claims are legitimate, programmes such as the TACR's training of tax officials should be further developed.

23. A complementary financing tool of innovation is demand-side measures to support innovation. Such measures can be useful in creating a market for innovation that addresses particular environmental and societal challenges (e.g. healthcare and pollution reduction). In particular, public procurement contracts have played a central role in creating leading innovation sectors in some countries (for instance defence spending in technology in Israel). Innovative pre-commercial public procurement is one such measure. In this case, a public contracting authority, for the purpose of purchasing goods, services or 
works, introduces into the procurement terms criteria that require innovative solutions. However, a strong regulatory framework should be put in place to make sure that young innovative firms have access and to avoid a technology lock-in situation (OECD, 2014a). Performance-based contracts with revision clauses can be effective to guarantee that the objectives of the public procurement contract are met.

\section{Venture capital}

24. Venture capital is very low in the Czech Republic (less than $0.006 \%$ of GDP in 2014). The share of venture capital in total investment in private equity (non-publicly traded companies) during the period 2007-10 amounted to just 3.2\% on average, which is far below the European level (12\%). Venture capital is almost inexistent for seed and start-up enterprises. Venture capital funds in the Czech Republic usually invest in later development stages of enterprises. This produces a financing gap due to the absence of a financial market for early-stage innovative companies. Also, banks and traditional financing institutions are not willing to finance risky projects with a high innovation potential.

25. To remedy these financing gaps for SMEs and start-ups, the government is planning to increase access to capital from public funds for SMEs and to facilitate the implementation of innovative competitive projects by SMEs under the Operational Programme Enterprise and Innovations for Competitiveness 2014-20. Support will be provided in the form of consultancy services for start-ups (business plan, legal advice, accounting, management, etc.) and financial instruments like grants for SMEs. The main framework for venture capital is the planned National Innovation Fund. It is a EUR 45 million investment platform dedicated to SMEs' and seed projects' financing. It will be managed initially jointly with the European Investment Fund and it seeks to mobilise private sector participation in equity financing.

26. While targeting the early financing of seeds and start-ups is appropriate given the lack of riskcapital available for these projects, the choice of instruments should be considered carefully. Some grants are necessary to encourage the development of innovative initiatives; however, the ex-ante assessment and selection process should be monitored strictly to avoid opportunistic behaviour and capture. Also, government support of equity investments in high-potential young firms should be done in partnership with the private sector (Wilson, 2015). Such an arrangement is likely to be more successful in fostering a sustainable venture capital sector and will help avoid the common pitfalls of government "picking winners". Therefore, increasing the participation of private sector actors such as banks via co-financing for instance could guard the National Innovation Fund against choices biased toward non-financial criteria for innovation perspectives. Moreover, in addition to venture capital, the development of seeds and start-ups necessitates a favourable ecosystem constituted of high quality infrastructure, available skilled human resources, frontier research and a business friendly environment (Wilson, 2015).

\section{Streamline the administration and implementation of innovation policy}

27. The organisation and administration of $\mathrm{R} \& \mathrm{D}$ and innovation policies is still too complex (see Box 2). Spending is divided among eleven ministries and bodies and seven types of financial support of different natures. This creates a fragmented system of support. Indeed, R\&D and innovation policies are developed and implemented in different government bodies, mainly in the Ministry of Industry and Trade, Ministry of Education, Youth and Sports (MEYS), the Academy of Sciences, the Czech Science Foundation, the Technology Agency of the Czech Republic (TACR), the Office of Government and the Research and Development Council. Also, different line ministries (defence, agriculture, etc.) run specific programmes. Some restructuring has already been made with the merging of some spending bodies in the TACR in 2009 (see Box 1) and by establishing the position of Deputy Prime Minister for Science, Research and Innovation in 2014. However, the innovation system still suffers from the specialisation of the different bodies each with a limited set of intervention instruments. The RDI targeted support from national funds can be done according to the RDI law only via grants, which prevents using any innovative 
instruments. Allowing the different institutions to use pooled instruments for interventions would increase their efficiency and reduce the number of interlocutors for enterprises. Restrictions on financial instruments available for innovation financing in the financial law governing $R \& D$ and innovation policies could be lifted.

28. There are also overlaps between the different strategies (Innovation, SMEs and Export) and programmes put in place for their implementation, not to mention initiatives at the regional and industry association level. The respective role of the different stakeholders should be further clarified as they all intervene in the three main areas (enabling environment, funding research projects and human resources). The establishment of an overarching strategy, the National Research, Development and Innovation Policy of the Czech Republic in 2016-2020, is also a first step to ensure consistency between the different strategies and programmes.

29. The policy design and the implementation of innovation policies should be streamlined and more co-operation should be sought. It is furthermore necessary to unify the design, assessment and coordination of the implementation of research and development and innovation policies in a single institution. The intended creation of the Ministry of Science and Research could be an opportunity to put all research institutions under the responsibility of the same institution and give that institution the mandate to coordinate and evaluate innovation policies.

\section{Box 2. Czech innovation policies and bodies: a complex organisational structure}

The Czech Republic innovation policy is a complex matrix of strategies, policy instruments, programmes and institutions.

\section{Strategies}

There are different strategies with overlapping goals and firm targets that contribute to innovation policies. The main ones are:

- The National Innovation Strategy of the Czech Republic 2012-20 adopted in 2011. The key objective is to reinforce innovation and the use of advanced technology as source of competitiveness. It is supplemented by the Conception of Support of Small and Medium Enterprises for the Period 2014-20 which is focused on four strategic priorities: (1) cultivation of business environment, development of advisory services and education for entrepreneurship, (2) development of business based on the support of research, including innovation and business infrastructure, (3) support of the internationalisation of SMEs, (4) sustainable energy development and innovation in the energy sector. This strategy is detailed annually in the Action Plan to Support Small and Medium-sized Enterprises, which defines the implementation of individual measures.

- The National Research, Development and Innovation Policy of the Czech Republic in 2016-2020 is the key document of the $R \& D$ area. It focuses on four strategic priorities: (1) consolidation of the management of R\&D; (2) improving public sector research quality; (3) co-operation between the private and public sectors in R\&D area and stimulating innovation in enterprises; (4) strategic focus of applied research according to the needs of users from the private and public spheres.

- The National Research and Innovation Strategy for Smart Specialization Czech Republic (RIS3 strategy) was also established as a precondition for the drawing of EU funds for RDI and is part of the national RDI strategy. It identified areas where policy actions are necessary to increase innovation performance of firms for competitiveness. Also, there is an initiative for Industry 4.0 created by the Ministry of Industry and Trade and targeting applied research.

\section{Programmes}

Several programmes are run to strengthen the innovation capability of the business sector. Significant efforts to promote innovation are channelled through the Technology Agency of the Czech Republic (see Box 1). In addition, the Operational Programme Enterprise and Innovations for Competitiveness 2014-20 (OPEIC) is mainly financed by EU funds. The OPEIC, conducted by the Ministry of Industry and Trade, is the third-largest fund for the period 2014- 
20 after operational programmes for Transport and Integration with a budget of EUR 4.3 billion. It is focused on supporting the development of R\&D for innovation, business development and competitiveness of SMEs, effective consumption of energy, energy infrastructure development and renewable resources, development of high-speed access networks and technical assistance.

\section{Institutions}

There are many institutions acting in the R\&D and innovation domain. The Ministry of Industry and Trade is the leading body on innovation policies. Many research organisations established their centres for technology transfer which are to ensure the link between research institutions and industry and application of research results. Another instrument for strengthening the link between research institutions and enterprises are Competence Centre projects under the programme of the TACR (see Box 1 on TACR).

Further support is provided by Czechlnvest, the Agency for Investment and Business belonging to the MIT. Its role is to attract foreign investment in manufacturing, strategic services and technology centres. Other support for RDI is provided by the Czech Science Foundation, Ministry of Industry and Trade, the Academy of Sciences and different line ministries.

The overall system appears highly fragmented, making it difficult to carry out an evaluation of the effectiveness and benefits of the overall RDI policy. An umbrella organisation with sufficient powers and the ability to implement and enforce its policies is necessary.

\section{Upgrading the innovation system will increase productivity and competitiveness}

\section{Foster the collaboration between businesses and public entities}

30. Limited collaboration between businesses and public research entities is one of the weaknesses of the innovation system. Only $14.4 \%$ of SMEs and $30.3 \%$ of large firms collaborate on innovation with higher education or research institutions (OECD, 2015a). Funding of higher education institutions from businesses is among the lowest in the OECD (Figure 12). Collaboration between research institutions and businesses is a factor of diffusion of innovation from frontier technology (Adalet McGowan et al., 2015). Also, given the strong presence of foreign firms, one could expect that Czech firms incorporate more externally developed innovations (Figure 13). Different factors are holding back the collaborative environment on RDI. First, local firms tend to be focused on production to meet demand from foreign companies, with a concentration and over-representation in the low value-added segments of the manufacturing value chain. Second, many firms are owned or affiliated with foreign firms which generally do not place innovation activities in the Czech Republic. Finally, Czech firms tend to lack non-technical management competencies, in particular, management of innovation capacities, to better exploit their technical competencies.

31. However, some specific manufacturing industries such as the automotive sector have set up successful collaborations with technological institutions and universities. There are already different strengths such as some successful research institutions, technological capacity, and supporting institutions that could be further capitalised on to enhance the collaboration between businesses and research institutions. A promising instrument in this area will be the realization of Operational Programme Enterprise and Innovations for Competitiveness 2014-20. The ALPHA and GAMMA programmes run by the Technology Agency to support applied research and experimental development could be strengthened and used to better target more results-focused projects.

32. Some mobility schemes for public researchers to work during some periods in businesses' research centres could be put in place to facilitate interactions between research institutions and firms. This would also enhance mobility and knowledge transfers between corporate and academic institutions. Some government funding for research projects developed inside firms could be tied to collaboration with public entities. 
Figure 12. Share of higher education R\&D financed by industry

2014 or latest available, in per cent

15

10

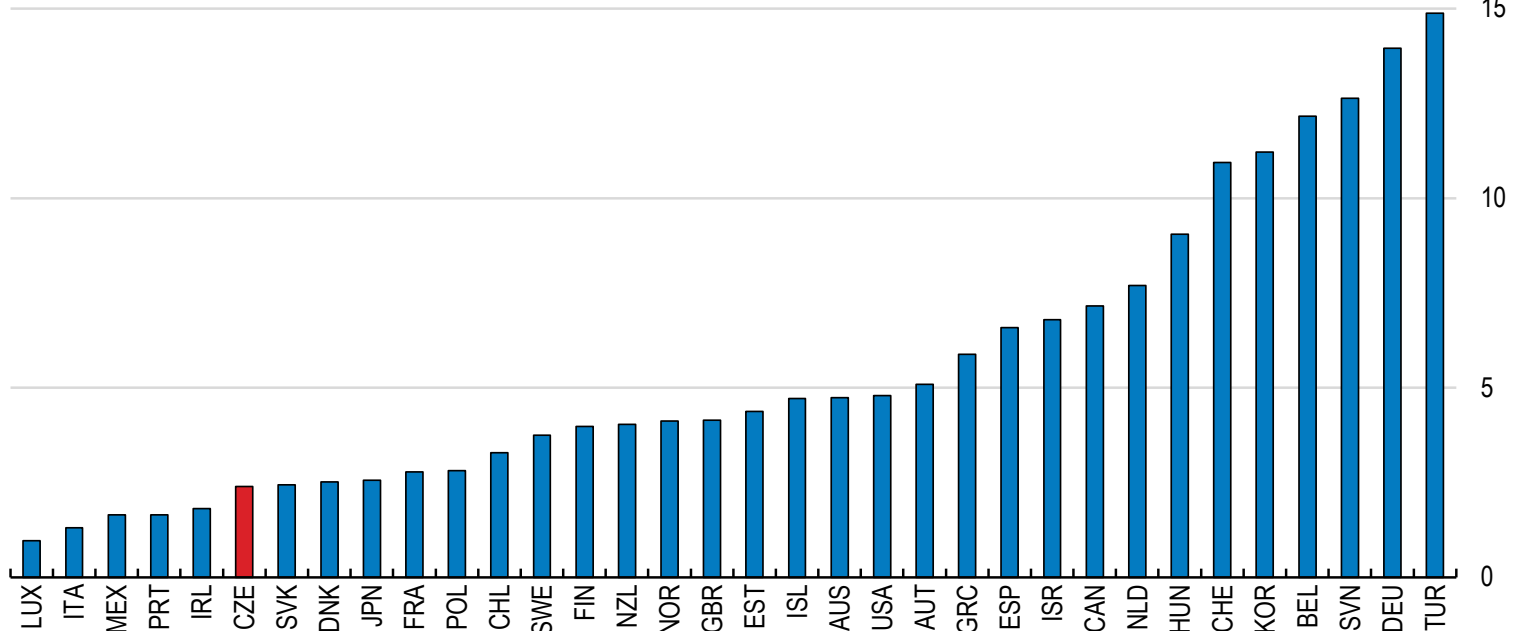

Source: OECD (2016), Main Science and Technology Indicators database. 
Figure 13. Externally developed goods and services used in innovation

As a percentage of firms introducing each type of innovation, 2010-12

\section{A. SMEs}
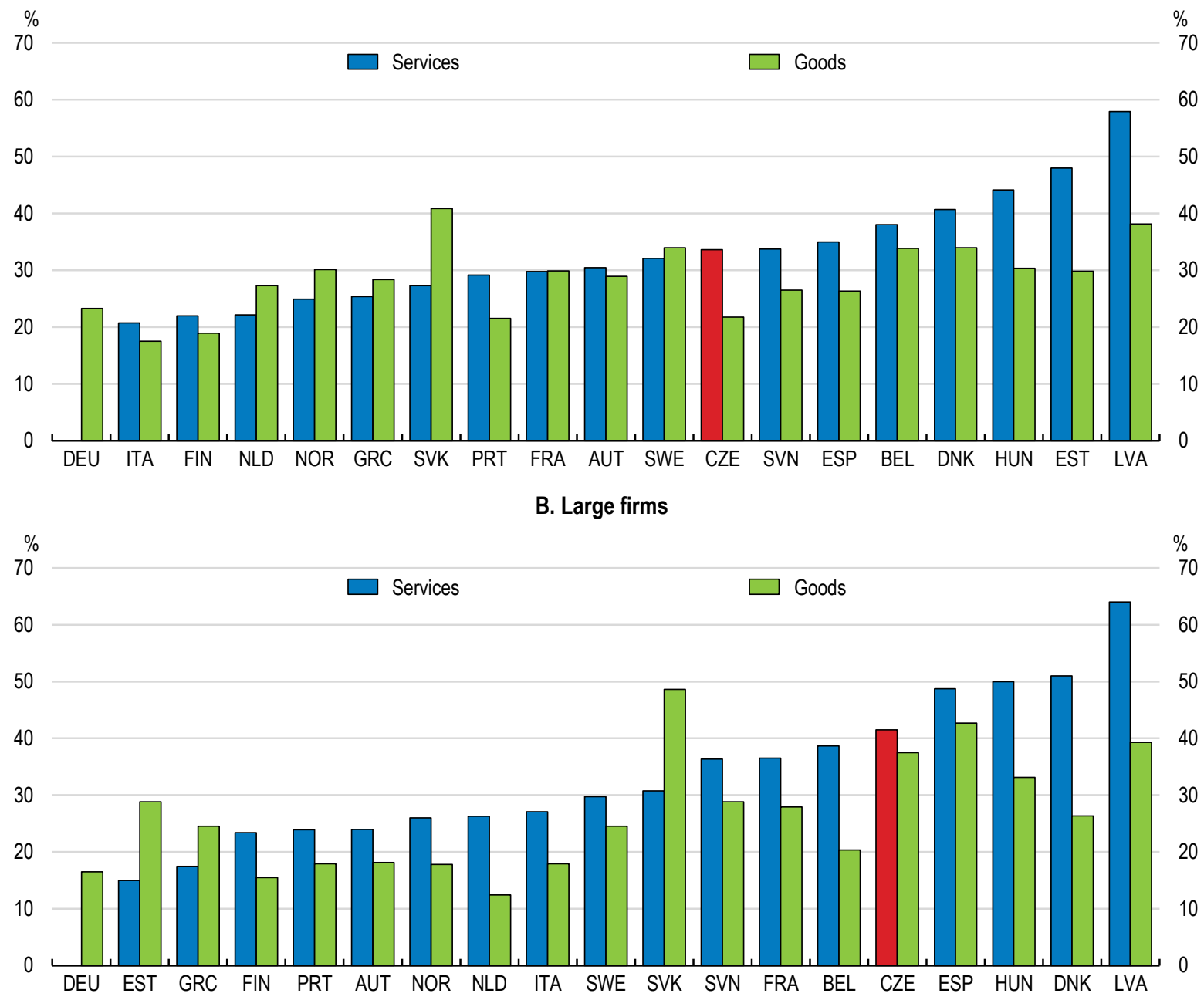

Source: OECD (2015), OECD Science, Technology and Industry Scoreboard 2015: Innovation for Growth and Society, OECD Publishing, Paris. http://dx.doi.org/10.1787/sti_scoreboard-2015-en

\section{Investment in knowledge-based capital to promote productivity diffusion}

33. Knowledge-based capital (KBC) is one of the key drivers of innovation and productivity growth. It also plays an important role in the diffusion of ideas and innovation adoption from global frontier firms to home frontier firms, and thereby fosters convergence and catch-up (Adalet McGowan et al., 2015). Knowledge-based capital refers to intangible assets or intellectual capital in three main groups: computerised information (e.g. software and databases); innovative property (patents, copyrights, designs and trademarks); and economic competencies (including brand equity, aspects of advertising and marketing, firm-specific human capital, etc.) (Corrado et al., 2009). The development of KBC depends on framework conditions, which foster innovation and within firm actions.

34. The Czech economy and firms appear weakly integrated in international knowledge flows and collaboration in science and innovation. While the number of international co-inventions seems 
satisfactory, the rate of international co-authorship is relatively low in science and innovation. Moreover, the number of international co-inventions is partly driven by the high presence of foreign owned or affiliated enterprises. The integration of Czech firms and universities in international scientific networks should be raised. A greater part of government R\&D grants should be directed to programmes including international collaborations under Czech leadership (which is less than $4 \%$ of government R\&D spending). Participation in international programmes would increase technology and knowledge transfers to and adoption in the Czech Republic.

35. The patenting activity of Czech firms should be further developed. It seems that Czech firms and innovators prefer patenting in other EU countries and the United States because of the large market size. However, given the royalties and externalities attached to patenting and the possibility of multiple registrations of patents and intellectual property rights, the government could put in place facilities (language and legal support, etc.) for international patenting, in particular at the EU level (European Patent Office). For instance, international trade in knowledge assets has increased noticeably (10\% average growth rate in 2009-13) in many countries and receipts represent 5\% of GDP in Israel and the Netherlands, compared with only $1.5 \%$ in the Czech Republic.

36. Organisational capacity is the combination of knowledge, processes and systems that allows firms to perform their activities efficiently. It can be defined as the know-how developed at the firm level. It is one of the most important elements in the differentiation of firms in terms of performance or productivity. Indeed, access to physical capital, technology and existing innovations is easier than access to intangible competencies in performing activities. Investment by Czech firms in organisational capital is very low, both in the manufacturing and services sectors (OECD, 2015a). Programmes could be put in place to raise top managers' awareness of the role of organisational capital, particularly as a strategic factor of firms' productivity and differentiation.

\section{Appropriate framework conditions are needed to increase productivity}

\section{Removing obstacles for firm expansion and start-up creation will boost productivity}

37. Start-ups and young SMEs often play a leading role in the introduction of advances in products, processes, organisational methods and marketing techniques. They push the economy toward the technological frontier and are thus conducive to rapid productivity growth (Adalet McGowan et al., 2015; Aghion et al. 2007), which in the long run is the fundamental driver of incomes and well-being. Many empirical studies have shown the close relationships between entrepreneurship and SME activity and economic growth and job creation (OECD, 2010a). A larger number of small businesses and start-up rates are associated with more rapid economic growth (Erken et al., 2008), and job creation (Neumark et al., 2008; Haltiwanger, 1999; Henrekson and Johansson, 2008).

38. Research from OECD countries highlights the role of young firms as job creators both through new start-ups and firm growth; young SMEs generated 42\% of new jobs on average over 2001-11 even though they represented 17\% of employment (Criscuolo, et al., 2014). The birth rate of enterprises (at least one employee) at $11.3 \%$ in 2012 in the Czech Republic compares well with the OECD average (OECD, 2015c). Most of them are very small (1-4 employees) and they are evenly distributed among industry, services and construction.

39. It is therefore critical for policy to stimulate start-ups' creation, firm expansion, knowledge development and exploitation in firms. In the SME Strategy 2014-20, the Czech Republic has four priorities set out (see Box 2). The implementation of the strategy should be accelerated. For instance, the one-stop-shop for start-up companies, to promote the direct registration of a new company in the 
commercial register of notaries and, in the second phase, the simplification of the registration and the reduction of fees, is still under examination by the parliament.

40. The strategy and its implementation should be strengthened, streamlined and simplified. There are too many instruments, calls for projects and grants that imply administrative costs for SMEs that apply. Indeed, an SME could need different types of support, which would imply addressing requests to different institutions. For instance, there are different bodies, instruments and calls devoted to the support of financially healthy businesses in search of investors (CzechLink programme), to consulting services for strategic management and innovation management (CzechInvest Agency), programmes aimed at improving the infrastructure for the development of human resources with an emphasis on technical education (CzechInvest Agency), soft loans and preferential loan guarantees for SMEs (CMZRB), and support for experimental development in the field of advanced technology, environment and energy and transport (TACR). Such streamlining would also ease access to finance for SMEs, which is particularly important in the Czech Republic as SMEs are the vast majority of firms.

41. While firm creation is important for innovation and productivity growth, ensuring the development of successful small firms will also boost productivity in the Czech Republic (Figure 14). Indeed, the gap between the productivity of small firms and large firms is important. The productivity of small-sized firms (up to 9 employees) is $60 \%$ and $40 \%$ lower than the productivity of large firms (250+ employees) in the manufacturing-construction and service sectors, respectively (Figure 14).

\section{Figure 14. Labour productivity of small firms is low}

2013 or latest, productivity of firms of 1 to 9 persons employed, index productivity of firms of more than 250 persons employed $=100$

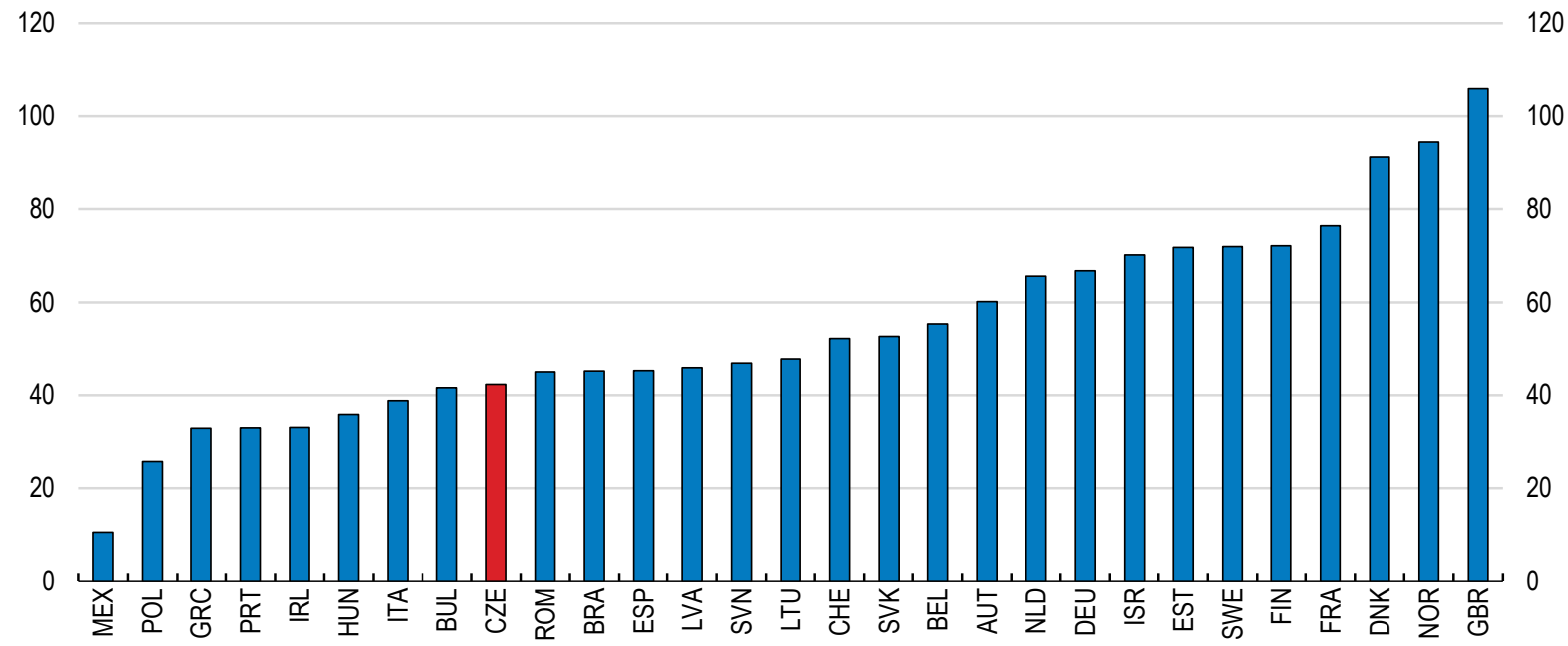

Note: Productivity is measured as value added per persons employed.

Source: Calculations based on OECD (2015), Entrepreneurship at a Glance.

42. Low productivity of SMEs is driven partly by the high incidence of self-employment in the Czech Republic. It has one of the highest percentages of self-employed workers in the European Union (see Appendix, Figure A.3). Self-employment is often less productive than employment in firms due to multi-tasking and other factors of scale. However, with an important manufacturing sector where many SMEs supply intermediate goods and services, there is room for bigger SMEs that could reap the benefits of economic scale and access to foreign markets. 
43. Boosting the growth and expansion of SMEs should be a more central and explicit target of government policy. The current strategies centre their action on support for innovation and export diversification. More attention should be paid to the framework conditions to favour SMEs' expansion (section on resource reallocation below).

\section{Improving the management quality of Czech firms}

44. Making the most of available resources and implementing new technologies and techniques to boost productivity requires managers with the necessary skills, knowledge and authority. Higher managerial quality has been shown to improve firm-level performance through the adoption and implementation of new technology and practices and to reduce skill mismatch amongst workers (Adalet McGowan et al., 2015; Bloom et al., 2012a, 2012b). A range of metrics related to managerial quality and practices suggest that Czech practices are outperforming CEE peers but further improvement is needed to catch up to other small, high income countries (Figure 15). Czech firms still have less reliance on professional management - an indicator of overall managerial quality from the Global Competitiveness Report that has been associated with faster convergence in multifactor productivity at the country level (Andrews and Westmore, 2014). There are also particularly large gaps in the perceived quality of management schools, which may contribute to gaps in the knowledge of best practice, and also in the willingness to delegate authority, which may limit firm growth but is dependent on trust and the quality of management at lower levels (Figure 15; Bloom et al., 2012c).

\section{Figure 15. Indicators of management quality and practices}

2015, scores range from 1 (lowest) to 7 (highest)

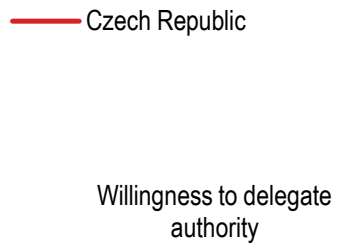

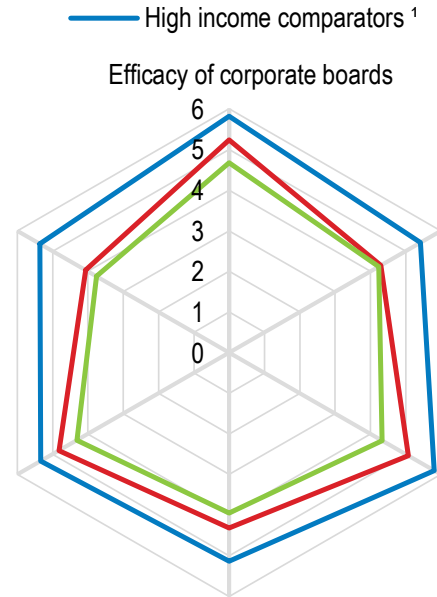

Extent of staff training

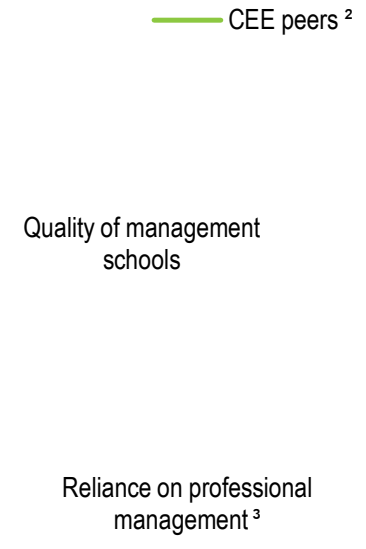

management $^{3}$

1. High income comparators are Austria, Belgium, Denmark and Sweden.

2. CEE peers are Estonia, Hungary, Poland, the Slovak Republic and Slovenia.

3. This variable takes the highest value (7) when senior managers are professional managers who obtained their position based on merit and qualifications and the lowest value (1) when senior management are mostly family and friends.

Source: Calculations based on World Economic Forum (2015), The Global Competitiveness Index Historical Dataset 2005-2015.

45. The aggregate figures mask heterogeneity within the economy. Managerial quality - as measured by literacy proficiency following Adalet McGowan and Andrews (2015a) - is much higher at large firms than at small firms (Figure 16). Similar results are found using numeracy proficiency as a measure of managerial quality. It is more efficient for better managers to be responsible for a larger share of economic 
activity (Adalet McGowan and Andrews, 2015a). However, in the Czech Republic, a much smaller share of the best managers (those with scores in the top quartile) are working in firms with over 250 employees compared to other small high income countries. Productivity-enhancing practices such as improvements to products and processes appear to be more common at foreign-owned firms, indicating better management (Table 1). This is consistent with findings for other countries in the World Management Survey (Bloom et al., 2014).

Figure 16. There is a large difference in managerial quality by firm size

Average literacy proficiency scores of managers by size of firm

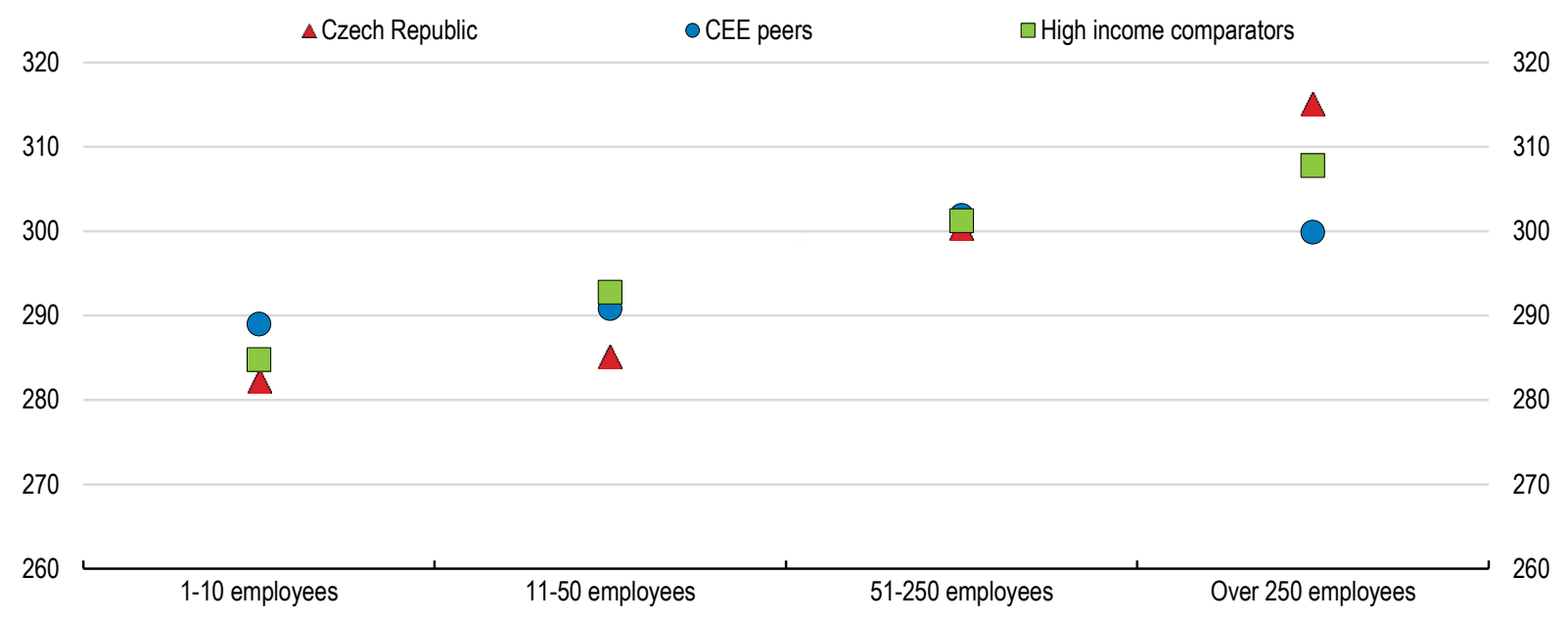

Note: CEE peers are Estonia, Poland and the Slovak Republic; high income comparators are Austria, Belgium, Denmark and Sweden. Averages for country groupings are unweighted.

Source: OECD calculations based on the Survey of Adult Skills (PIAAC) (2012).

Table 1. Management outcomes by ownership and sector

Per cent of firms undertaking activity

\begin{tabular}{|c|c|c|c|c|}
\hline & \multicolumn{2}{|c|}{ By ownership } & \multicolumn{2}{|c|}{ By sector } \\
\hline Share of firms that implemented: & Domestic & $\begin{array}{l}\text { Foreign- } \\
\text { owned }\end{array}$ & Manufacturing & $\begin{array}{l}\text { Market-based } \\
\text { services }\end{array}$ \\
\hline New/improved products or services & 51.5 & 61.9 & 60.3 & 46.8 \\
\hline New/improved production or supply methods & 30.6 & 41.7 & 39.2 & 26.4 \\
\hline New/improved organisational practices or structures & 24.3 & 26.9 & 28.6 & 21.2 \\
\hline New/improved marketing methods & 21.9 & 40.6 & 23.5 & 27.3 \\
\hline Employee ideas developed & 52.3 & 69.6 & 56.8 & 54.3 \\
\hline
\end{tabular}

Note: The survey question asked about changes made in the previous three years. Establishments are classified as foreign owned if they are at least $50 \%$ foreign owned. The sample is restricted to the sectors shown. Caution is warranted due to the small sample size. The median weights from the survey have been applied. Market-based services include services in: trade; accommodation and food; information and communication; finance; real estate; professional; and administrative services.

Source: OECD calculations based on the EBRD-World Bank Business Environment and Enterprise Performance Survey 2013.

46. Lower investment in managerial skills is also likely to be affecting the diffusion of knowledge of best practices. Czech firms seem to invest less in managerial organisational capital than in non-managerial 
training, whereas the reverse is typically true elsewhere (OECD, 2015a). The amount is also smaller: in 2011-12 the Czech private sector invested half of the typical investment made in countries with available data. The PIAAC data show that $63 \%$ of Czech managers had undertaken some job-related training in the previous year, a lower share than in most other countries. Training was more common at larger firms. The quality of existing training may also need to be raised (Figure 15). Good practices would be diffused more effectively by lowering barriers to the mobility of talented managers within the labour market, as discussed below. Encouraging skilled immigration could also help implementation of best practices. Some improvement may also occur naturally over time as the PIAAC data indicate that managerial quality is highest for managers aged 25-44 years. However, reforms that increased competitive pressures, as discussed below, could also spur improvements in management techniques (Adalet McGowan and Andrews, 2015b; Bloom et al., 2012b).

\section{Skill mismatch is high and likely affecting productivity}

47. Lower managerial quality is also associated with skill mismatch, which is particularly high in the Czech Republic relative to other OECD countries (Figure 17). This measure (following the definitions in Adalet McGowan and Andrews (2015a) and OECD (2013)) suggests that a relatively small share of Czech workers is under-skilled but a relatively high share of workers $-16 \%$ - is over-skilled. At the economy-wide level, this will constrain productivity to the extent that these over-skilled workers could be better employed by other more productive firms. At the firm level, over-skilled workers also represent an under-utilised resource, perhaps due to lower management quality. Estimates from OECD countries suggest that improving the quality of managerial capital to the level of Finland (best practice) would also reduce the probability of skill mismatch by around 5\% and increase labour productivity by almost $2 \%$ (Adalet McGowan and Andrews, 2015b).

Figure 17. A relatively high share of Czech workers are over-skilled

Measure of skill mismatch in literacy, per cent of workers

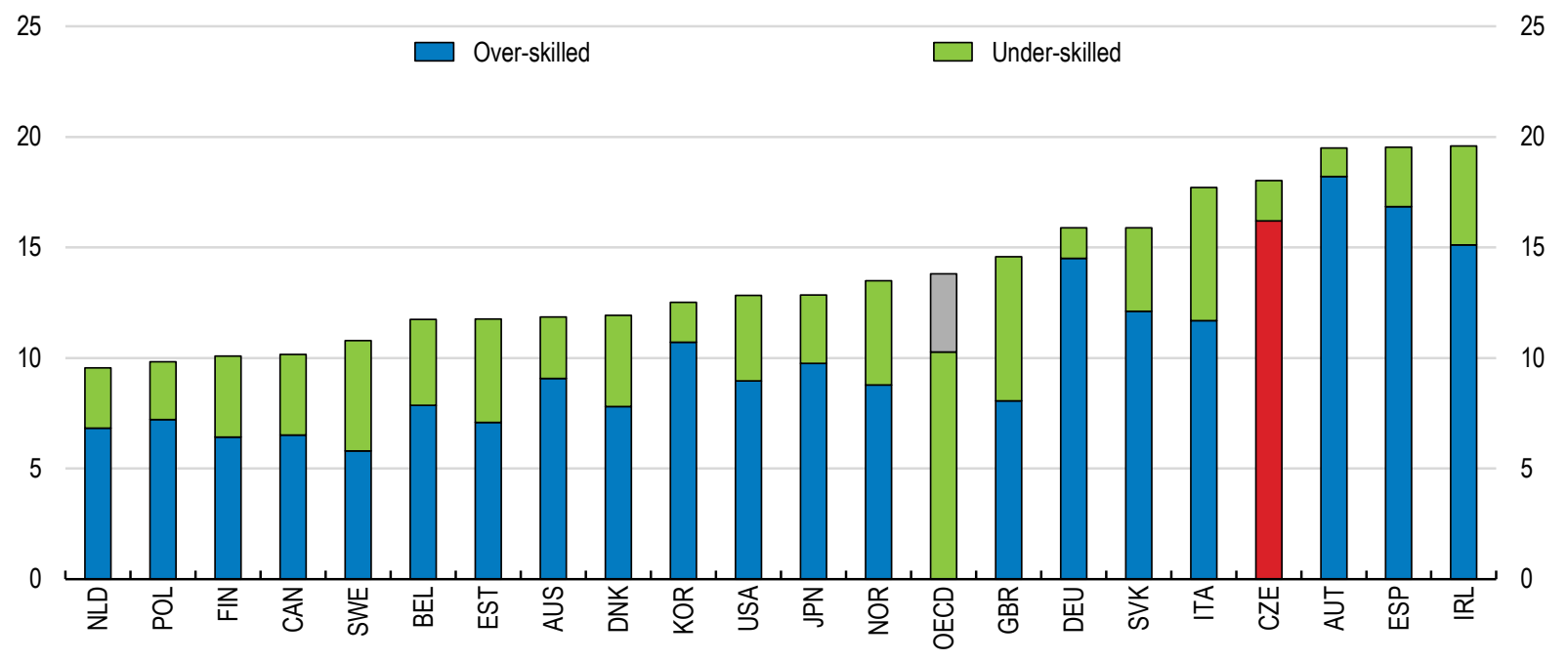

Note: Data for Belgium are from Flanders and data for the United Kingdom are from England and Northern Ireland. Mismatched workers are those whose literacy proficiency score is in the top or bottom $5 \%$ of self-reported well-matched workers in their country and occupation.

Source: OECD (2013), Skills Outlook 2013: First Results from the Survey of Adult Skills, OECD Publishing, Paris.

48. The probability of a worker being over-skilled reflects individual characteristics of the worker and their job, as well as characteristics of the economy and the policy environment. Younger and more 
educated workers are more likely to be over-skilled, even when other individual characteristics are controlled for (Table 2; Adalet McGowan and Andrews, 2015b). Although these patterns are common across countries, the effects are larger in the Czech Republic, particularly for level of education, and may in part be related to the important increase in tertiary graduates in the past decade, which has not been matched by enough change in labour demand. Workers whose studies were in the fields of humanities or sciences are also more likely to be over-skilled (Table 2). Montt (2015) shows that mismatch between field of study and occupation is comparatively high in the Czech Republic. Improving the match between education and labour market needs could therefore help to reduce mismatch, for example by publishing information on labour market outcomes by field of study and institution, modifying financing for a better match of VET programmes and increasing incentives to participate in lifelong learning, as recommended in OECD (2014b).

49. Mismatch would be reduced by removing barriers to the mobility of resources and workers and promoting competition. In particular, there could be large impacts from lowering the cost associated with closing a business (discussed below) and reducing the stringency of employment protection legislation (Figure 18). The protection of workers against individual dismissal is the second-highest in the OECD, which affects hiring and firing decisions and reduces the quality of matches between workers and jobs.

50. Measures that increase geographic mobility may help workers move to more productive jobs. With privatisation and successive reforms, the private rental market has expanded considerably over two decades but it remains small relative to Western European countries (14\% of the housing stock in 2011) (de Boer and Bitetti, 2014). Reforms since 2012 reduced rent control and increased landlord rights but their effectiveness is limited by long eviction procedures and the consequent use of temporary contracts makes private rental insecure (de Boer and Bitetti, 2014). Measures to reduce the high transaction costs associated with housing transactions could also lower barriers to mobility. Improving transport linkages could also reduce mismatch by increasing the range of jobs that a worker can reach. This could include raising the quality of roads to lower travel times and securing a more competitive rail sector (OECD, 2014b).

51. There is a risk that isolated actions to increase the flexibility and productivity of the economy and raise the returns to skills, which are currently low in the Czech Republic, cause income inequality to rise from its currently low level (OECD, 2015d). While reducing skill mismatch should imply higher wages, it may not happen uniformly across the skill distribution, especially because the returns to skills are higher for low-skilled workers than to high-skilled workers. Policymakers should therefore reduce the linkages between socioeconomic background and education (as proposed in earlier Economic Surveys) and ensure the tax-benefit system helps offset the resulting effects on inequality. 
Figure 18. Estimated labour productivity gains from moving policy-related factors to best practice

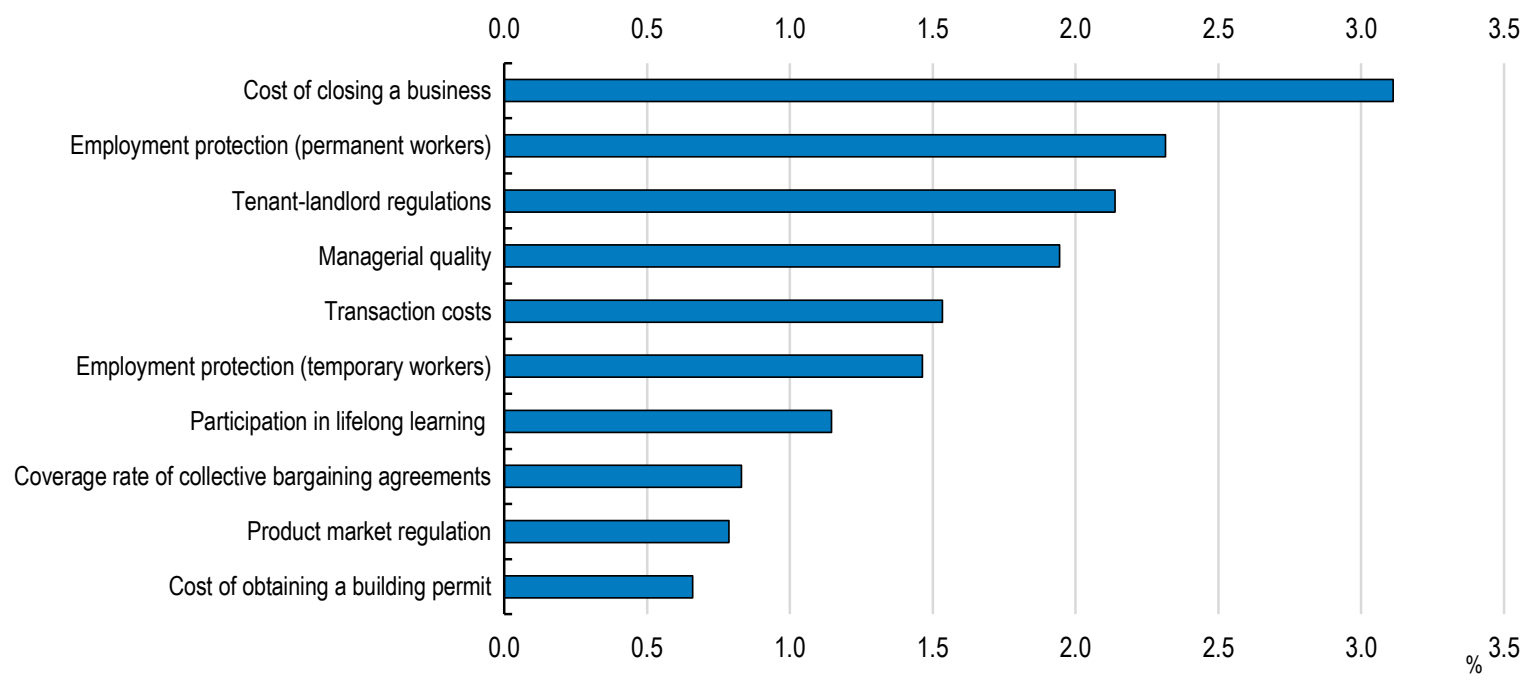

Note: Estimates are based on: i) logit regressions of probability of mismatch controlling for age, marital and migrant status, gender, education, firm size, contract type, a dummy for working full-time and working in the private sector; and ii) OLS regressions of labour productivity on skill mismatch.

Source: Adalet McGowan, M. and D. Andrews (2015), "Skill Mismatch and Public Policy in OECD Countries", OECD Economics Department Working Papers, No. 1210, OECD Publishing, Paris.

\section{Box 3. Skill mismatch and worker characteristics}

Recent studies using the OECD Survey of Adult Skills (PIAAC) data highlight the link between skill mismatch and productivity as well as the importance of field of study (Adalet McGowan and Andrews (2015a); Montt (2015)). This box builds on the relationship between over-skilling and worker characteristics in Adalet McGowan and Andrews to consider field of study and industry.

Variable definitions generally follow Adalet McGowan and Andrews (2015a), with insignificant variables excluded to preserve degrees of freedom. Even after allowing for educational attainment and age, workers whose studies were general, in "humanities, languages and arts", in "social sciences, business and law" or in "science, maths and computing", are more likely to be over-skilled in their current job (Column 2 and 4). Workers in the manufacturing sector are more likely to be over-skilled than those in primary industries, construction and energy (Column 3 and 4). However, manufacturing workers with non-tertiary post-secondary education are less likely to be over-skilled (Column 5). 
ECO/WKP(2016)86

\section{Table 2. Overskilling and worker characteristics}

Dependent variable $=1$ if the worker is overskilled and 0 otherwise

(1)

Female
Aged 25-34
Aged 35-44
Aged 45-54

Aged $55+$

Upper secondary education

Post-secondary, non-tertiary

Tertiary education

Firm size: 11-50 employees

Firm size: 51-250 employees

Firm size: over 250 employees

Studied humanities/social sciences

Studied science

Manufacturing sector

\section{Services sector}

Manufacturing ${ }^{*}$ upper secondary

Manufacturing ${ }^{*}$ post-secondary

Manufacturing*tertiary

Services*upper secondary

$-0.085^{\star}$

$(0.022)$

0.016

$(0.034)$

$-0.080^{* *}$

$(0.033)$

$-0.104^{\star \star \star}$

(0.037)

$-0.152^{\star \star \star}$

(0.040)

$0.152^{\star *}$

(0.072)

$0.279^{\star \star *}$

(0.101)

$0.223^{* * *}$

$(0.072)$

0.033

(0.027)

$-0.073^{* *}$

$(0.031)$

0.027

$(0.032)$

(0.032)

es

(2) $-0.102^{*}$
$(0.025)$
0.013

$(0.025)$
0.013

$(0.037)$

$-0.079^{* *}$

(0.036)

$-0.107^{\star * *}$

(0.040)

$-0.158^{\star * *}$

(0.041)

0.130

(0.088)

$0.252^{\star \star}$

$(0.113)$

$0.183^{\text {** }}$

(0.091)

0.036

(0.028)

$-0.077^{\star *}$

(0.033)

0.022

(0.033)

$0.163^{\star * *}$

(0.040)

$0.065^{\text {** }}$

(0.031)

condary

Services*post-secondary

\section{Services*tertiary}

Number of observations

2724

2536

(3)

$-0.086^{* * *}$

(0.023)

0.017

(0.033)

$-0.075^{\star *}$

(0.033)

$-0.100^{* * *}$

(0.037)

$-0.146^{* * *}$

(0.039)

$0.154^{* *}$

(0.071)

$0.282^{* * *}$

$(0.102)$

$0.229^{\star \star *}$

(0.072)

0.029

(0.028)

$-0.084^{\star *}$

(0.033)

0.014

(0.033)

(4)

$-0.103^{\star \star \star}$

(0.026)

0.015

(0.036)

$-0.070^{* *}$

(0.036)

$-0.099^{* *}$

(0.039)

$-0.150^{\star \star *}$

(0.039)

$0.141^{*}$

(0.085)

$0.264^{* \star}$

(0.113)

$0.200^{* *}$

(0.088)

0.031

(0.029)

$-0.092^{* \star *}$

$(0.035)$

0.003

(0.034)

$0.167^{\star \star *}$

(0.041)

$0.076^{\star *}$

(0.031)

$\begin{array}{ll}0.068^{* *} & 0.076^{* \star} \\ (0.029) & (0.030) \\ 0.035 & 0.021\end{array}$

0.035

(0.031)

0.046

$(0.030)$

(0.140)

$-0.159$

$(0.105)$

0.067

(0.143)

$-0.564^{\star \star \star}$

(0.214)

$-0.102$

$(0.161)$

$0.225^{*}$

(0.116)

$-0.326$

(0.207)

0.137

(0.123)

Note: Estimates are from logit regressions. All variables are dummy variables. The omitted categories are: male; age 15-24; basic education; firm of 1-10 employees; studied a general programme, teacher training, engineering, manufacturing and construction, agriculture and veterinary science, health and welfare or services; works in primary industries, construction, electricity, water or the energy sector. Values shown are marginal effects, corresponding to the impact of a change in the explanatory variable on the probability of mismatch at the mean of the explanatory variable. Robust standard errors are shown in parentheses. ${ }^{* * *},{ }^{* *}$ and * denotes statistical significance at the $1 \%, 5 \%$ and $10 \%$ level, respectively.

Source: OECD calculations based on the Survey of Adult Skills (PIAAC) (2012). 


\section{Raising competition and resource re-allocation to boost productivity}

\section{Favouring resource re-allocation to boost productivity}

52. Efficient allocation of resources by favouring the entry and growth of SMEs would improve productivity. Indeed, it allows the replacement and exiting of less productive firms and the allocation of resources (capital and human resources) to dynamic firms. Andrews and Cingano (2012) show that barriers to firm entry, stringent bankruptcy legislation, employment protection legislation and unfavourable financing conditions can undermine resource allocation and productivity. They find evidence that higher barriers to firm entry and more stringent bankruptcy legislation tend to disproportionately lower allocative efficiency in industries characterised by high firm turnover relative to low turnover industries. Similarly, tighter employment protection legislation is found to disproportionately lower the efficiency of employment allocation in high layoff industries. Also, restrictions on competition in finance and low financial development are associated with lower productivity. And, these results tend to be more detrimental in innovative sectors. These results are in line with different findings in the literature (Hopenhayn and Rogerson (1993) on tax wedge effects; Barseghyan and DiCecio (2011) on entry costs; Moscoso-Boedo and Mukoyama (2012) on entry regulation and firing costs; and Buera et al. (2010) on the role of financial frictions and credit underdevelopment).

\section{Bankruptcy procedures are too costly}

53. Bankruptcy legislation is important for allocative efficiency. Costly and time-consuming insolvency procedures dent resource re-allocation between lower productivity firms and better performing ones (Adalet McGowan et al., 2015). However, bankruptcy laws have to be balanced between encouraging entrepreneurship and the reallocation process and protecting creditors and suppliers, in particular of SMEs. Low recovery rates for creditors may cause tighter credit conditions, reducing access to finance for firms.

54. In the Czech Republic, the bankruptcy legislation allows any entity (individuals as consumers or indebted and individual entrepreneurs) to resolve its negative economic situation by filing an insolvency petition. There are three basic types of settlement methods - bankruptcy, reorganisation and discharge. However, SMEs principally qualify for reorganisation and discharge only under specific conditions. The actual process is mainly focused on preserving creditor claims. It is therefore restrictive for entrepreneurs, in particular for small ones. Indeed, the process excessively requires that creditors or a majority of them agree with the solution proposed. Also, when bankruptcy resolution does not successfully satisfy creditors, remaining claims are not extinguished and persist to burden the debtor. Among the features of the insolvency proceedings in the Czech Republic that are known to increase the duration and tend to be detrimental to efficient process are: persistent insufficient protection from (bullying) unjustified insolvency petitions and restrictive conditions imposed on majority vote among creditors on insolvency proceedings.

55. Overall, the process remains too formal, slow and costly (Figure 19). It often requires the assistance of a lawyer. The government could consider reforms that simplify the process for very small entities with small liabilities. Also, possibilities to delay the process either by the creditor or debtor should be reduced. For instance, majority vote among creditors on insolvency proceedings could be put in place to help speed up insolvency procedures. Finally, an amendment allowing the write-off of debtor liabilities at the end of the judicial proceedings should be introduced. 
Figure 19. The cost of bankruptcy proceedings is high

Average cost of bankruptcy proceedings as a percentage of the estate's value

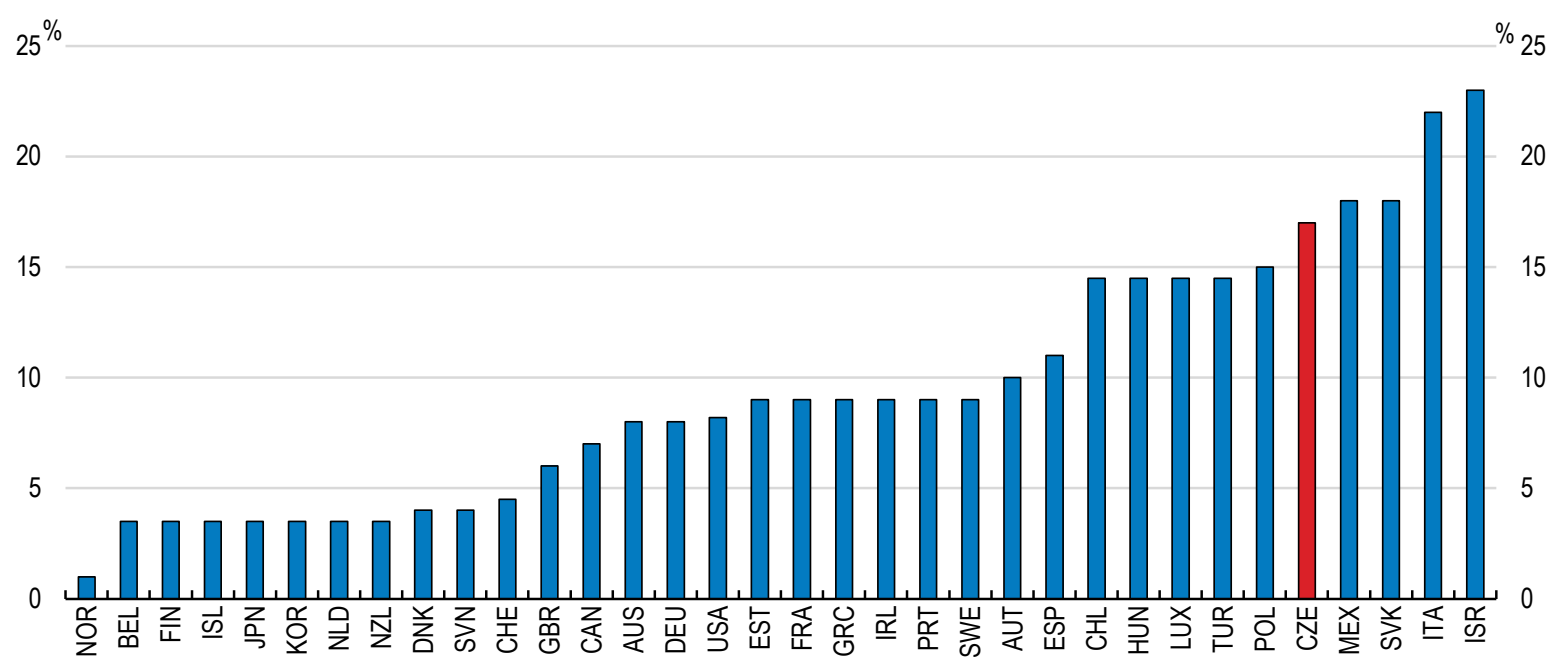

Note: The cost is calculated on the basis of questionnaire responses and includes court fees and government levies; fees of insolvency administrators, auctioneers, assessors and lawyers; and all other fees and costs.

Source: World Bank, Doing Business database.

There is still room for improving the competition and regulation framework

56. The Czech Republic has undertaken many reforms to establish a competitive market economy in recent decades. Czech competition law is harmonised with EU competition rules. Nevertheless, according to EU's Consumer Markets Scoreboard which assesses consumer conditions the Czech Republic is below the EU average (Figure 20).

Figure 20. Consumer market scoreboard: Czech Republic versus EU average

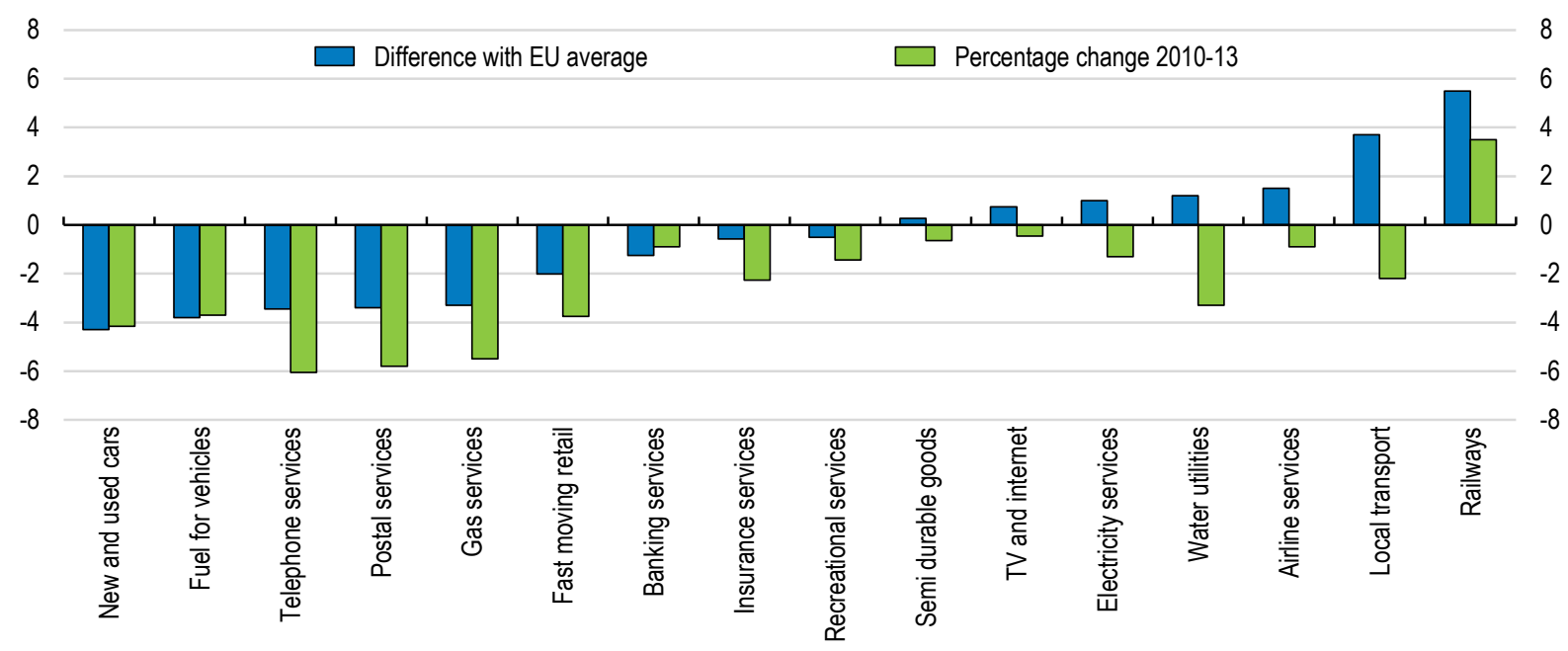

Source: European Commission (2014), Consumer Markets Scoreboard: Making markets work for consumers, 10th edition, June 2014. 
57. Also, as already extensively assessed in the 2014 Czech Republic Economic Survey (OECD, 2014b), competition and regulation can be improved. In particular, significant barriers to entrepreneurship remain according to OECD Product Market Regulation Indicators (Figure 21). For instance, barriers to entrepreneurship are much higher in the Czech Republic compared to Slovakia. Also, in terms of the severity of barriers, the Czech Republic is amongst the member states with the highest number of regulated professions. Therefore, reform to open regulated professions is needed.

58. The Office for the Protection of Competition is in charge of enforcing competition law. The overall situation and performance assessment of the agency has not changed since the publication of the 2014 Economic Survey. Agency resources are still insufficient and mostly devoted to public procurement with a high staff turnover rate due to short tenure, which partly reflects low wages. The resources of the Office should be increased to allow it to better perform its duty and its regulatory power strengthened.

Figure 21. Barriers to entrepreneurship, 2013

\section{3, Index scale 0-6 from least to most restrictive}

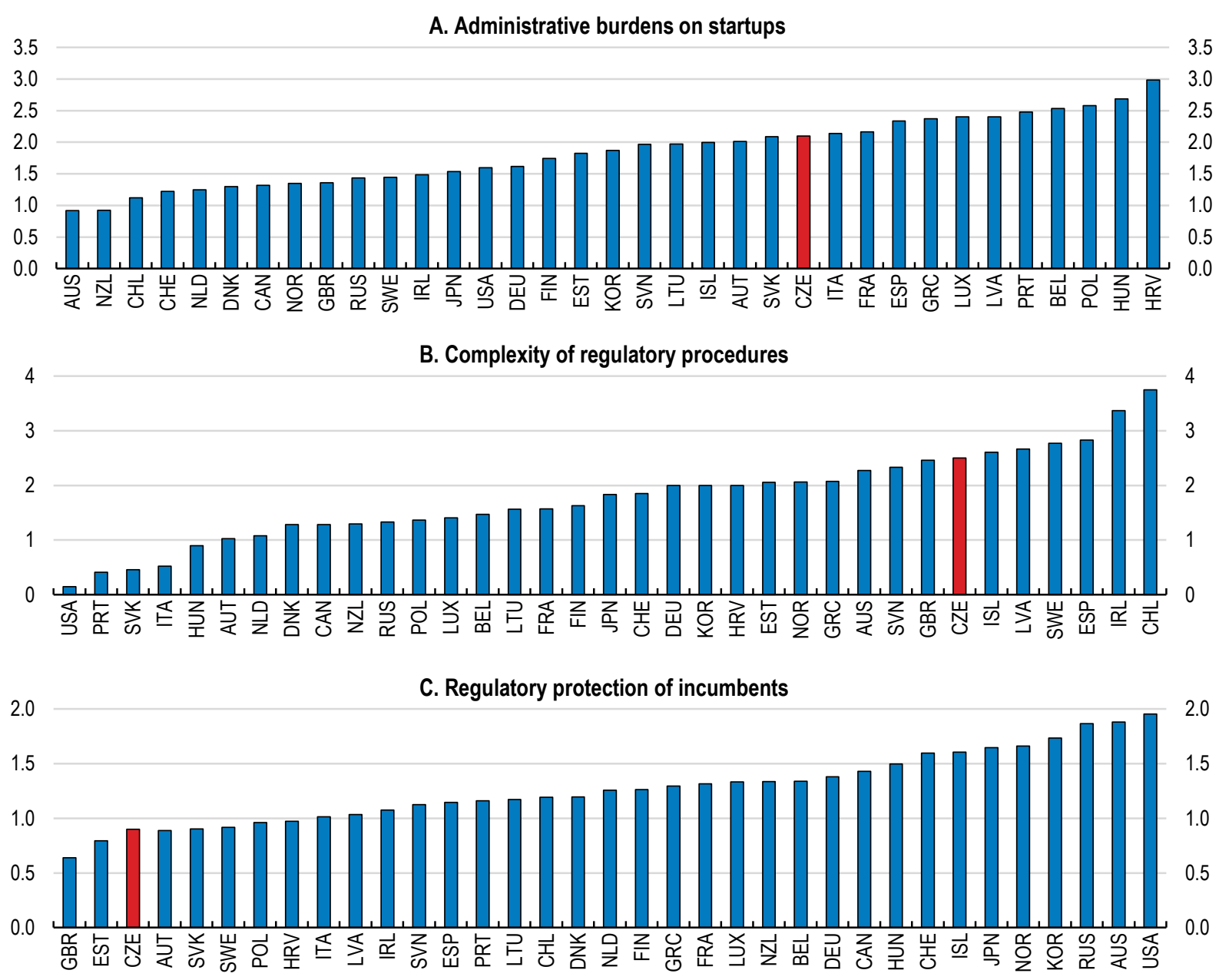

Note: For the United States, data refer to 2007

Source: OECD, Product Market Regulation Database, www.oecd.org/economy/pmr, June 2015. 


\section{Streamlining access to finance for SMEs}

59. The financing of SMEs and young firms is an important dimension of resource re-allocation and the development of young high potential firms. It is furthermore important for the development of innovative firms. Access to finance for SMEs is particularly important in the Czech Republic as SMEs with less than 9 employees represent $95 \%$ of all enterprises (OECD, 2015c).

60. Business financing has been decreasing in the Czech Republic since the crisis, particularly from 2009 (Figure 22, Panel A). On the one hand, the application of stricter rules for credit by banks led to more selectivity of borrowers and higher loan collateral and, on the other hand, the demand from entrepreneurs was lower due to gloomier economic perspectives and higher uncertainty (OECD, 2015e). New SME loans peaked in 2008 and then contracted by $31 \%$ over the 2008-11 period as the global crisis hit (Figure 22, Panel B). However, loans increased in 2015 along with GDP growth.

61. The Czech government has set up or strengthened different financial institutions to develop the financing of SMEs, including the Czech-Moravian Guarantee and Development Bank (CMZRB) (see Box 4), the Czech Export Bank and the Export Guarantee and Insurance Corporation. The financing takes different forms with guarantees for loans and for exports playing a major role. Different programmes are in place to support the financing of SMEs (see Box 5). There is a need to streamline the framework so that entrepreneurs and SMEs do not face too many institutions when they are looking for financing. The instruments could be refined to make sure that they really correspond to the needs of entrepreneurs, in particular of start-ups. Indeed, start-ups in general do not look for loans or guarantees on their loans but for capital. The creation of a government-sponsored investment fund is welcomed and can help the development of venture capital. Its creation should be accelerated. Another important instrument envisaged and jointly financed by the EU is a guarantee fund for innovative SMEs to be managed by the CMZRB. The guidelines for the insurance and guarantee programme for innovation managed by the CMZRB still need to be vetted by the EU for the implementation of innovation programmes relying on EU funding. There is also a need to accelerate the process for this programme to start operating.

\section{Box 4. The Czech-Moravian Guarantee and Development Bank}

The Czech-Moravian Guarantee and Development Bank, Inc. (CMZRB) was founded in 1992 as a specialised banking institution to support small and medium-sized enterprises. The bank's shareholder is the Czech Republic, which holds $100 \%$ of the shares and all voting rights. The Czech Republic is represented by the Ministry of Industry and Trade, Ministry of Regional Development and the Ministry of Finance.

Although the provision of services expanded over the years, the support for small and medium-sized enterprises (SMEs) is still the main task. Besides the support of government programmes for SMEs, the bank has expanded its activities to include support in the areas of housing and financing of municipal development projects in the area of infrastructure. The Bank provides bank guarantees, soft loans, grants and related banking services. The main clients are SMEs and owners of apartment buildings (housing cooperatives and apartment owners).

The Bank offers the following kind of products/services:

- $\quad$ The guarantee programme 2015-23 in collaboration with the Ministry of Industry and Trade (MIT). The main goal of the programme is to facilitate access to bank financing for SMEs. The programme provides guarantees up to $80 \%$ of the principal amount of the loan, under the limit of CZK 30 million for the principal (loan). The programme also supports social entrepreneurs who employ disadvantaged people by a contribution up to $10 \%$ of the guaranteed loan, up to CZK 500000 . Loans and guarantees are provided directly by commercial banks, which have a contract with CMZRB. In the initial years of the programme, the fund will be able to guarantee loans of up to CZK 5.3 billion. 
- Another guarantee programme is INOSTART, which is designed for start-ups. Pilot projects have started in the Moravian-Silesian and Olomouc Region and the programme was later extended to the entire country.

- In 2014, CMZRB enhanced co-operation with the Czech Export Bank, which finances SME exports. CMZRB continues to provide export guarantees and direct export credits.

- In the framework of the regional programme, the CMZRB provides soft loans for SMEs in the SouthBohemian Region for the acquisition of fixed assets and inventories with a favourable interest rate for a period of 6 years.

- Another important programme of the CMZRB also provides guarantees for a bid in open tender from CZK 50000 up to CZK 5 million. Guarantees as collateral are provided if the subject of the tender is the supply of products, goods, services and works for tenders announced by entities registered in the Czech Republic.

- CMZRB is also an intermediary under the Multiannual Programme for the Competitiveness of Enterprises and SMEs 2014-20 (COSME). It is the first programme linked to the so-called Juncker package. The COSME is implemented and funded by the European Commission and implemented by member states. CMZRB will provide guarantees for investment loans and loans for the purchase of supplies up to CZK 4.1 million for SMEs (up to 50 employees).

- Municipalities have also access to CMZRB financing through four programmes: (1) preferential regional loans for Municipalities in the South Bohemian Region, (2) long-term loans funded by the Regional Development Fund, (3) municipal loans in the programme OBEC 2, (4) and municipal loans in the Municipal Loan programme 2 (MUFIS 2).

Figure 22. Business loan growth of financial institutions

A. Bank lending has been hit by the crisis

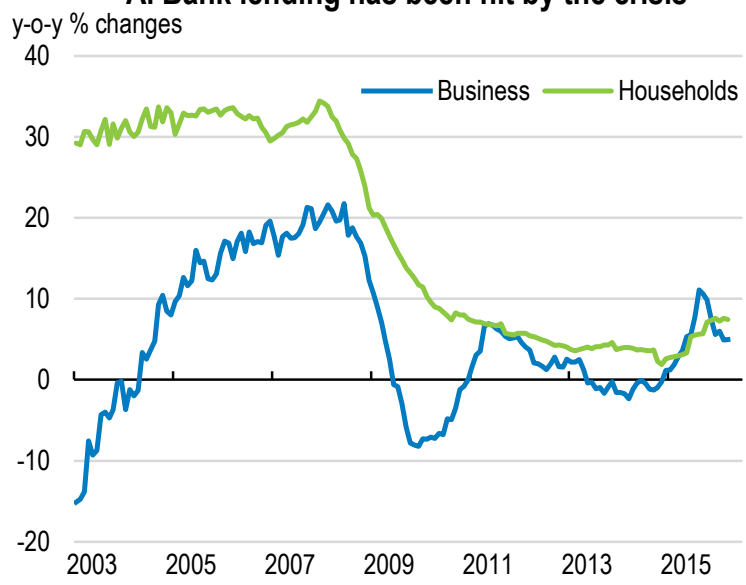

\section{B. New business loans}

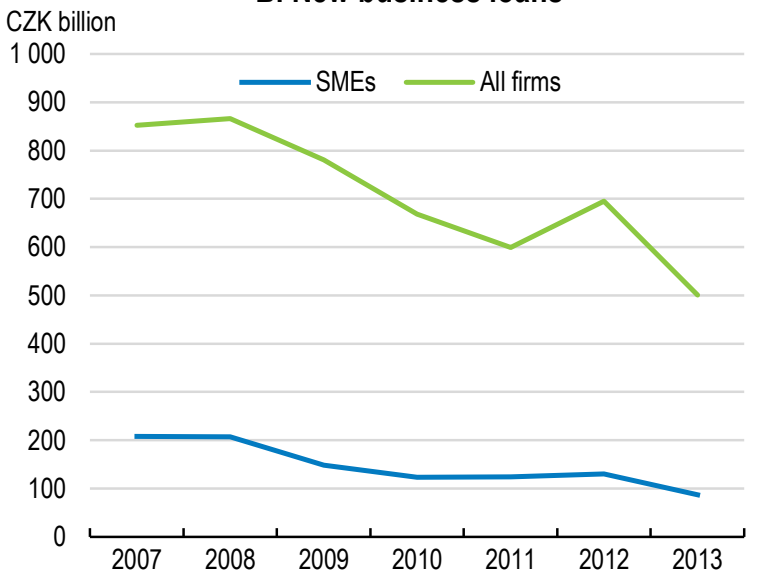

Source: European Central Bank and OECD (2015), Financing SMEs and Entrepreneurs. 


\section{Box 5. SME financing programmes}

The government policy support to SMEs' financing is based on the Act No. 47/2002 Coll., on support to small and medium-sized enterprises and the document Small and Medium-sized Enterprises Support Strategy 2014-20 (Ministry for Industry and Trade).

Operational Programme Enterprise and Innovation 2007-14 (OPEI) was the financial instrument funded from the EU Structural Funds 2007-13 for the support of firms' competitiveness. OPEI was focused on indirect and direct support for entrepreneurs, especially SMEs and in general to overcome existing barriers of access to capital. Support was provided primarily to businesses with higher innovation potential, to stimulate R\&D in enterprises, to establish cooperation between academia and business and to encourage starting-up new businesses.

The GUARANTEE programme (which was a part of OPEI) for small businesses uses the resources from terminated guarantees and repaid loans. The guarantee fund is administered and managed by CMZRB. During 2013, the programme was extended to support entrepreneurs affected by the floods. In this programme, CMZRB cooperates with private partner banks and provides SMEs with partial guarantees (between $60-80 \%$ of the loan provided by the private bank) (see Box 4).

The REVIT programme focuses on support of SMEs operating in regions with lower and declining economic activity and high unemployment (i.e. structurally disadvantaged regions) or in regions affected by natural disasters. The programme enables SMEs to gain preferential loans (usable for covering investment or operational costs) and grants. The programme is funded from the national budget and is administered and managed by the CMZRB.

The INOSTART programme is focused on supporting innovative start-ups characterised by large risks, a short financial history and low collateral to raise funds. The programme allows novice innovative entrepreneurs (up to 3 years of business activity) to gain access to credit through a guarantee for loans up to $60 \%$ of the outstanding loan principal. Entrepreneurs can obtain guarantees for loans up to CZK 15 million. The programme also includes advisory services related to the strategic management and the implementation of business plans. Starting from May 2014 the programme was extended to medium-sized enterprises and to all regions of the Czech Republic.

Source: OECD (2016), Financing SMEs and Entrepreneurs 2015: An OECD Scoreboard

\section{Reform taxation of SMEs and the self-employed}

62. The efficiency of resource allocation is influenced by the structure of taxes on businesses and revenues of the self-employed. The statutory corporate income tax rate of $19 \%$ is low by international standards. Nevertheless, there is a risk that the pattern of SME growth could be distorted by differential treatment of firms in the tax system. One particular issue is the development of self-employment. Selfemployed workers are $17 \%$ of total employment (Figure 22). That number is particularly high for a country which does not have an important agricultural sector (Araújo and Maleček, 2015). In part, this may be induced by the tax structure, which gives preferential treatment to the self-employed in comparison with employees. The total tax burden for an average employee (including social security contributions) reached $37 \%$ in 2013 , compared to $28 \%$ for an average self-employee, yet self-employees' average gross earnings were 34\% higher than those of employees (Araújo and Maleček, 2015). For instance, based on an annual cash-flow threshold of CZK 2 million, self-employees benefit from income tax deductions of up to $80 \%$ of their cash-flows or revenues for self-employed workers in agriculture, craftsmen, etc., $60 \%$ for other selfemployed workers, $40 \%$ for artists, writers and other intellectual activities and $30 \%$ for revenues from house rental and associated categories, which comes on top of preferential treatment with respect to social security contributions. These deductions seem particularly generous (OECD, 2015f) and these thresholds can generate strategies to avoid crossing the threshold, such as inefficient splitting, which slows down the reallocation process (Chen and Mintz, 2011). 
63. Indeed, this tax structure is suspected to have led to the development of strategic sub-contracting by firms which reduces the tax base for both firms and the self-employed. Indeed, the low tax burden for the self-employed has led to a phenomenon of false self-employment (commonly referred to as "svarcsystém" in Czech), with employees not benefitting from a standard contract with their employer, working instead as a self-employed worker (OECD, 2010b; Araújo and Maleček, 2015). Given the negative effect of self-employment on tax revenues and the PAYG pension pillar, an amendment of the Act on Income Taxes imposed ceilings for flat-rate tax deductions for self-employees, effective from 2015, which should somewhat reduce the attractiveness of false self-employment. The tax structure could be reformed to ensure less distortion with size.

\section{Leveraging the high participation in global value chains to increase productivity}

64. The Czech economy is one of the most integrated in global value chains (GVC) (Figure 23). However, its participation is highly concentrated within European value-chains. The foreign content of the Czech Republic's exports (45.1\%) was amongst the highest in the OECD in 2011. Of the Czech Republic's total exports of domestic value-added in 2011, 58.6\% reflected exports of intermediates (OECD/WTO, 2016). Also, $41 \%$ of the Czech Republic's domestic value added was driven by foreign final demand.

Figure 23. Participation in global value chains is high

\section{$2011, \%$ of gross exports}

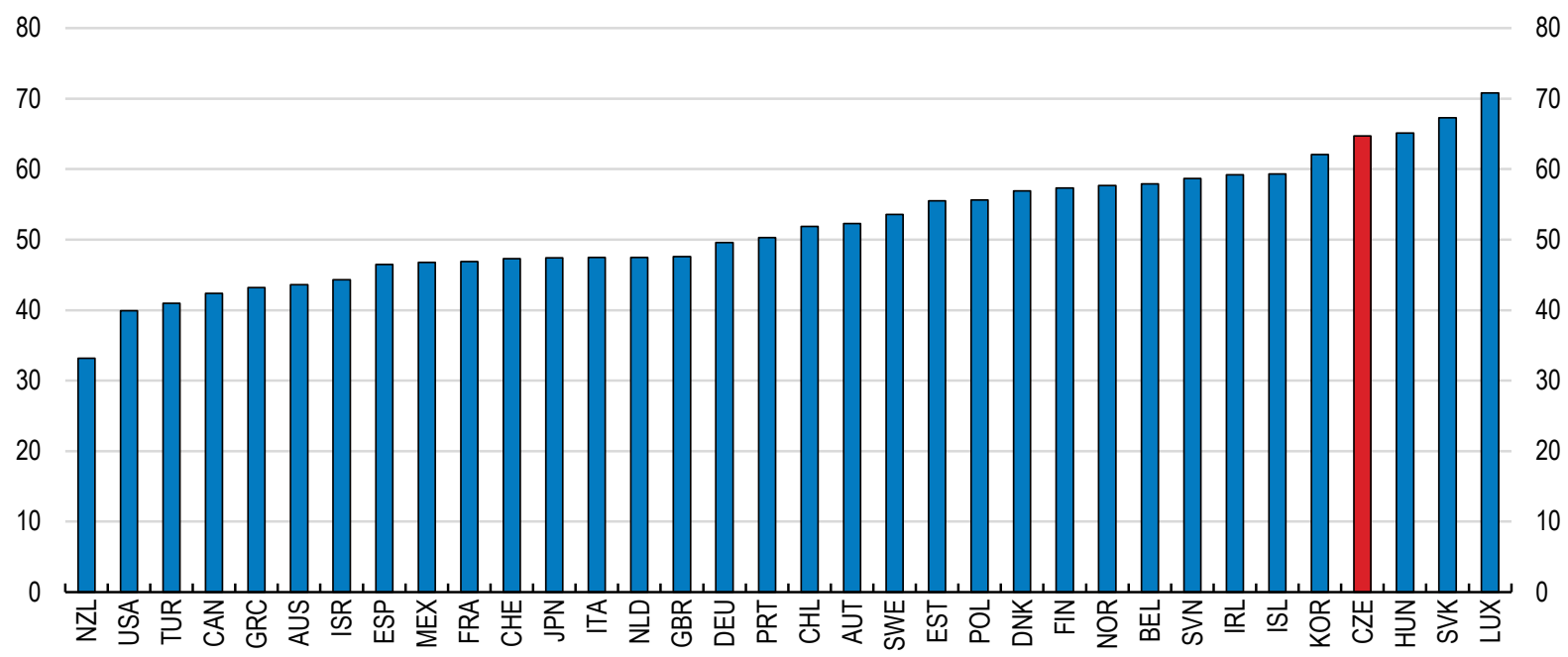

Note: The indicator, as proposed by Koopman et al. (2010), is expressed as the share of foreign inputs (backward participation) and domestically produced inputs used in third countries' exports (forward participation) in a country's gross exports. Further details can be found in the OECD Trade Policy Paper No. 159.

Source: OECD, Trade in Value Added (TiVA) - October 2015: Trade in Value Added (TiVA): Forward and backward linkage indicators.

65. Participation in GVC affects productivity through different channels including FDI and outsourcing. Different studies have tried to estimate the impact of FDI on the economy. For instance, Harding and Javorcik (2012) suggest FDI inflows can lead to an increase in the quality of exports in developing countries in both absolute terms and in terms of bridging the distance to the quality frontier. Also, Javorcik (2008) reports that the presence of multinationals can lead to knowledge spillovers to local firms in the same industry or to local firms in the supplying sectors, which can facilitate product upgrading. For instance, in a recent World Bank survey, 24\% of local enterprises in the Czech Republic and 15\% in Latvia reported that they have learned about the availability of new technologies by observing 


\section{ECO/WKP(2016)86}

multinational enterprises operating in their country and their sector. Half of the suppliers of multinationals surveyed in the Czech Republic reported improving their quality control systems in response to the request of their multinational customers.

66. However, the spillover effects of FDI inflows are not straightforward to capture and estimation results are mixed. Some studies have focused on German investments in the Czech Republic. German enterprises are the most important partners of the Czech economy, in particular in the manufacturing sector. Overall, the existing evidence indicates that the vertical integration model accounts for a much larger share of German direct investment in Central and Eastern Europe than in other major destinations (Marin et al., 2003; Gauselmann et al., 2011). However, the results depend a lot on threshold effects and variables to disentangle vertical and horizontal integration. Moreover, Stancik (2007) found that domestic companies tend to be negatively affected by the presence of foreign companies in the Czech Republic, especially in upstream sectors. Havranek and Irsova (2011) found that vertical spillovers tend to be somewhat more positive in this respect. Münich et al. (2014) analyse the spillover effects between German firms and Czech affiliates by types of legal relationship. They find that both greenfield and M\&A Czech daughters are significantly less likely to be high-tech than their German mothers in manufacturing, but there does not seem to be a statistically significant difference in the service sector.

67. More importantly, Münich et al. (2014) find that from the Czech point of view, "the cross-border investment in manufacturing generates jobs for low-skilled workers, possibly reducing unemployment in this segment of the labour market, but the investment projects fall short of expectations as far as their contribution to technological upgrading is concerned as they predominantly deepen specialization of the local economy in low-tech jobs". However, cross-border investment in the service sector appears much more promising in terms of stimulating the upgrading process. Indeed, the deepening fragmentation of production makes a lock-in situation in the low-cost edge of global production networks more likely than before.

68. One way to capture the benefits from GVCs is through outsourcing. One can distinguish outsourcing of services from material outsourcing and also domestic outsourcing from offshore outsourcing, which designates the sourcing of inputs from outside the boundaries of the firm and beyond home country borders. At the industry level, using intermediate inputs as a proxy for outsourcing, OECD input-output data show that the degree of outsourcing varies across the manufacturing sector likely depending on the position as suppliers or assembler in the value chain. However, in the motor vehicles sector, one of the most important manufacturing sectors in Czech Republic, the degree of outsourcing is relatively low compared to other countries (Figure 24). Outsourcing of services is relatively low in all sectors as illustrated in Figure 24. Therefore, Czech firms may not be benefiting from the productivity gains outsourcing can generate.

69. Estimates of the impact of outsourcing on productivity at the firm or industry level are mixed and very dependent on the industry or country and even firm specific characteristics. For instance, Görzig and Stephan (2002) on German firms find a positive and significant effect of outsourcing on firm performance, measured as returns per employee. This effect is strongest for material outsourcing, but negative for services in the short run. Moreover, they find that increased subcontracting and outsourcing of services reduces firm profitability, whereas firms engaged in material outsourcing tend to do better than those that do not outsource. Such result implies that there is a limit to outsourcing. Girma and Görg (2004) analysed the impact of outsourcing on both labour productivity and TFP for three separate UK manufacturing industries over the period 1982-92. They found a positive and significant impact of outsourcing on productivity levels for plants in the chemical and engineering industries. However, the effect of outsourcing in the electronics sector is negative though not significant. 
70. More recently, Schworer (2013), focusing on Europe between 1995 and 2008, shows that many services that were previously provided internally have systematically been outsourced. He finds evidence that service offshoring and offshoring of non-core manufacturing activities have contributed to an increase in productivity, whereas no significant link is found for offshoring of core manufacturing activities and domestic outsourcing. From an extensive survey of the empirical literature, Olsen (2006) concludes that there are no clear patterns as to how outsourcing affects productivity, and much seems to depend on both sector- and firm-specific characteristics. In particular, there are several indications that part of the productivity-enhancing effects from offshore outsourcing is driven by firm-specific strategic elements such as increasing the focus on core competencies.

\section{Figure 24. Intermediate inputs in key manufacturing sectors}

\section{Services input as percentage of gross output, 2011}

\section{A. Motor vehicles and trailers}
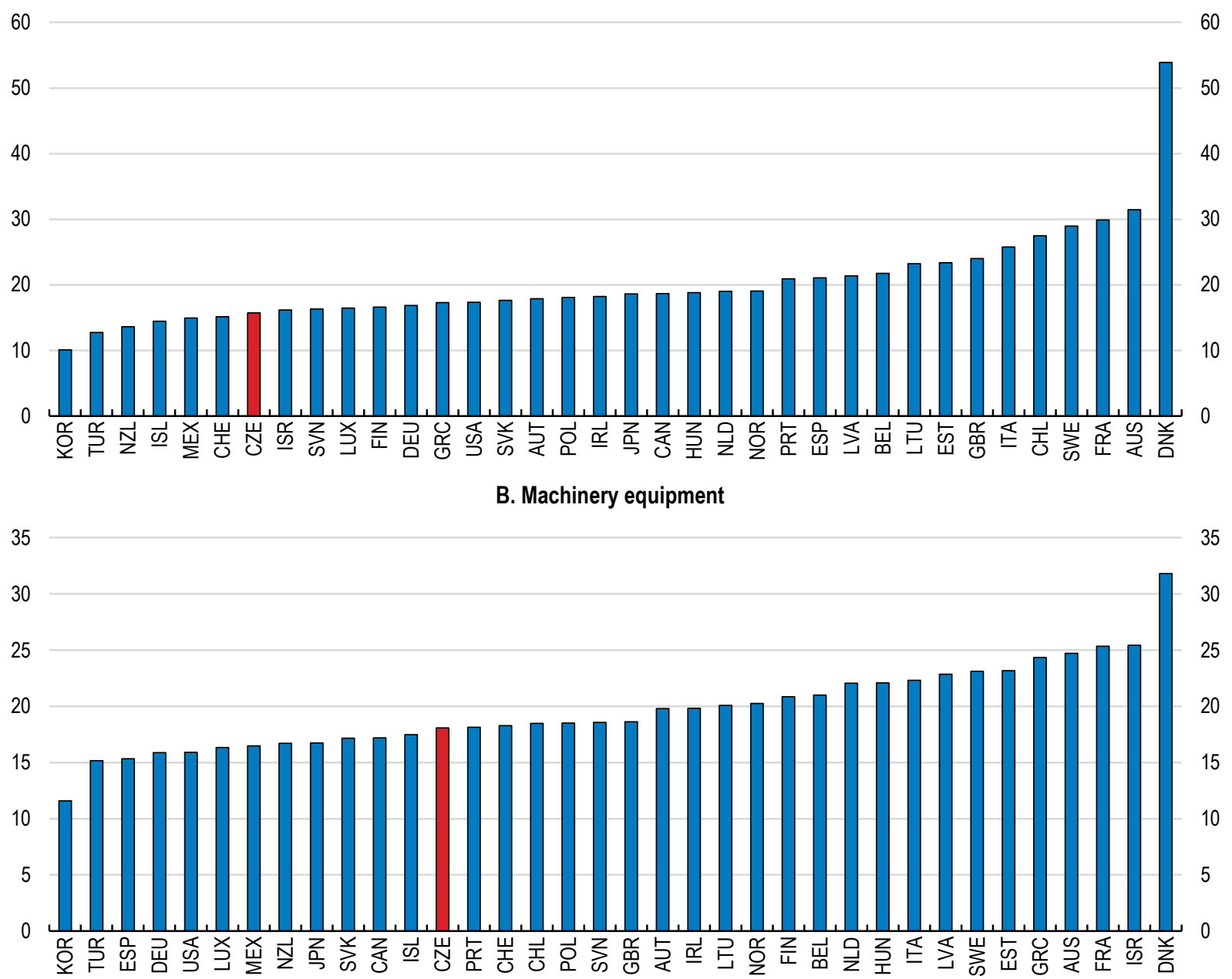

Source: OECD calculations based on OECD Input-Output database.

71. The analysis of the impact of outsourcing on labour productivity at the industry level in the Czech Republic suggests that Czech firms may not reap all the productivity gains they could from services outsourcing. Figure 25 shows that when compared to countries in the same segment in global value chains (Estonia, Lithuania, Poland and Slovakia) Czech firms incorporate lower level of services outsourced in their production and experience a lower labour productivity growth rate. 
Figure 25. Services outsourcing and labour productivity growth in the manufacturing sector

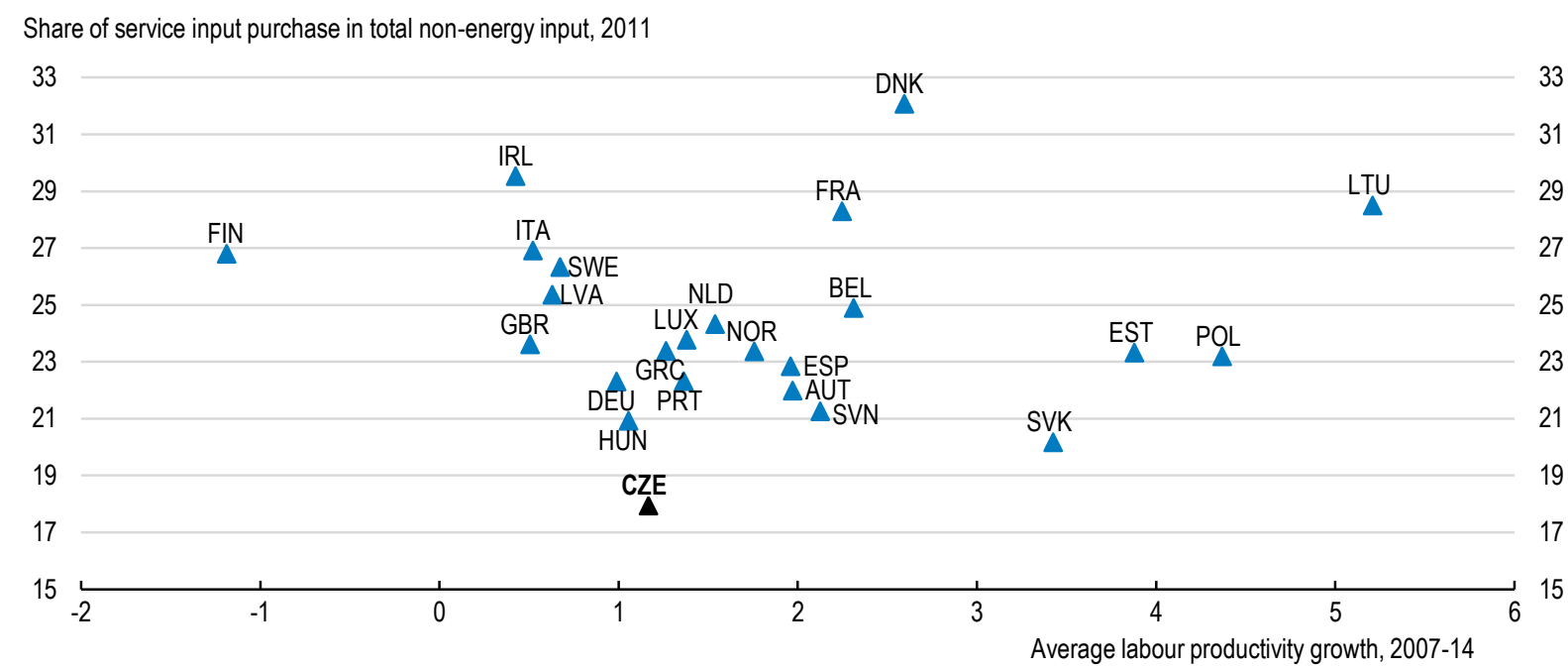

Source: OECD calculations, Input-Output OECD database.

\section{Recommendations to foster productivity growth and income convergence}

\section{$R \& D$ and innovation systems}

- Develop government co-financing schemes to complement grants and increase fiscal incentives for business R\&D spending.

- Unify the design, assessment and coordination of research and development and innovation policies in a single institution. Specifically, research institutions should be under the responsibility of the same institution.

- Increase R\&D spending effectiveness by better targeting government funding to broaden the scope of $R \& D$ activities in the Czech Republic.

- Increase incentives and funding through the national programmes of applied research and innovations to develop collaboration between research entities and businesses.

- Develop mobility schemes for public researchers to work during some period in businesses' research centres to facilitate the inter-actions between research institutions and firms.

- Use public procurement contracts to initiate innovative solutions in strategic areas with societal benefits.

- Encourage the participation of managers and workers in training and further education to increase the productivity of staff. Offer individual training accounts or refundable tax credits to individuals that undertake training at accredited institutions.

- Remove the barriers to the mobility of workers to reduce skill mismatch by improving the functioning of the private rental market, lowering the cost of closing a business and easing the stringency of employment protection legislation.

\section{Creating a productivity enhancing environment}

- $\quad$ Limit the possibilities to delay bankruptcy procedures and eventually allow for the write-off of debts. 
- Reduce the number of regulated professions and strengthen the competition and regulatory framework of product markets.

- Accelerate the creation of funds and guarantee programmes to support SMEs and innovation.

- $\quad$ Reduce the advantages of self-employment in terms of social contributions and personal income tax.

\section{Other recommendations}

- Increase the share of government R\&D grants directed to programmes including international collaborations and to support activities conducive to the acquisition of knowledge-based capital.

\section{REFERENCES}

Adalet McGowan, M., D. Andrews, C. Criscuolo and G. Nicoletti (2015), The Future of Productivity, OECD Publishing, Paris. http://dx.doi.org/10.1787/9789264248533-en

Adalet McGowan, M. and D. Andrews (2015a), "Labour Market Mismatch and Labour Productivity: Evidence from PIAAC Data”, OECD Economics Department Working Papers, No. 1209, OECD Publishing, Paris. http://dx.doi.org/10.1787/5js1pzx1r2kb-en

Adalet McGowan, M. and D. Andrews (2015b), "Skill Mismatch and Public Policy in OECD Countries", OECD Economics Department Working Papers, No. 1210, OECD Publishing, Paris. http://dx.doi.org/10.1787/5js1pzw91nwk-en

Aghion P., T. Fally and S. Scarpetta (2007) "Credit Constraints", Economic Policy, Vol. 22(52), pp. 731-779.

Andrews, D. and F. Cingano (2012), "Public Policy and Resource Allocation: Evidence from Firms in OECD Countries", OECD Economics Department Working Papers, No. 996, OECD Publishing, Paris. http://dx.doi.org/10.1787/5k9158wpf727-en

Andrews, D. and B. Westmore (2014), "Managerial Capital and Business R\&D as Enablers of Productivity Convergence", OECD Economics Department Working Papers, No. 1137, OECD Publishing, Paris. http://dx.doi.org/10.1787/5jxx3d441knr-en

Araújo, S. and P. Maleček (2015), "Strengthening Skill use and School-to-work Transitions in the Czech Republic", OECD Economics Department Working Papers, No. 1206, OECD Publishing, Paris. http://dx.doi.org/10.1787/5js1pz2xnm6b-en

Barseghyan, L. and R. DiCecio (2011), "Entry costs, industry structure, and cross-country income and TFP differences", Journal of Economic Theory, 146(5), pp. 1828-1851.

Bloom, N., R. Sadun and J. Van Reenen (2012a), “Americans Do IT Better: US Multinationals and the Productivity Miracle", American Economic Review, Vol. 102, No. 1, pp. 167-201. 
Bloom, N., C. Genakos, R. Sadun and J. Van Reenen (2012b), "Management Practices Across Firms and Countries", NBER Working Papers, No. 17850.

Bloom, N., R. Sadun and J. Van Reenen (2012c), "The Organization of Firms Across Countries", Quarterly Journal of Economics, Vol. 127, No. 4, pp. 1663-1705.

Bloom, N., R. Lemos, R. Sadun, D. Scur, and J. Van Reenen (2014), "The New Empirical Economics of Management", NBER Working Papers, No. 20102.

Buera, F. J, J. P. Kaboski and Y. Shin (2010), "Finance and Development: A Tale of Two Sectors", American Economic Review, 101(5), pp. 1964-2002.

Chen, D. and J. Mintz (2011), "Small Business Taxation: Revamping Incentives to Encourage Growth", The School of Public Policy Research Papers, Vol. 4, No. 7, University of Calgary.

Corrado, C., C. Hulten and D. Sichel (2009), "Intangible Capital and US Economic Growth", Review of Income and Wealth, Vol. 55, No. 3, pp. 661-685. http://dx.doi.org/10.1111/j.14754991.2009.00343.x

Criscuolo, C., P. Gal and C. Menon (2014), "The Dynamics of Employment Growth: New Evidence from 18 Countries", OECD Science, Technology and Industry Policy Papers, No. 14, OECD Publishing, Paris. http://dx.doi.org/10.1787/5jz417hj6hg6-en

Dall'Olio, A., M. Iootty, N. Kanehira and F. Saliola (2014), "Enterprise Productivity: A Three-Speed Europe", ECB Working Papers, Series No. 1748, December.

de Boer, R. and R. Bitetti (2014), “A Revival of the Private Rental Sector of the Housing Market?: Lessons from Germany, Finland, the Czech Republic and the Netherlands", OECD Economics Department Working Papers, No. 1170, OECD Publishing, Paris. http://dx.doi.org/10.1787/5jxv9f32j0zp-en

Erken, H., P. Donselaar and R. Thurik (2008), "Total Factor Productivity and the Role of Entrepreneurship", Jena Economic Research Papers 2008-19, Friedrich Schiller University and the Max Planck Institute of Economics, Jena.

Gauselmann, A., M. Knell and J. Stephan (2011), "What Drives FDI in Central-Eastern Europe? Evidence from the IWH-FDI-Micro Database", Post-Communist Economies, Vol. 23, No. 3, pp. 343-357.

Girma, S. and H. Görg (2004), "Outsourcing, Foreign Ownership, and Productivity: Evidence from UK Establishment-level Data”, Review of International Economics, Vol. 12, Issue 15.

Görzig, B. and A. Stephan (2002), "Outsourcing and Firm-level Performance", German Institute for Economic Research Discussion Paper, No. 309.

Haltiwanger, J. (1999), “Job Creation and Destruction by Employer Size and Age: Cyclical Dynamics”, in Z. Acs, B. Carlsson and C. Karlsson (eds.), Entrepreneurship, Small and Medium-Sized Enterprises and the Macroeconomy, Cambridge University Press, Cambridge.

Harding, T. and B. S. Javorcik (2012) "Foreign Direct Investment and Export Upgrading”, Review of Economics and Statistics, Vol. 94, No. 4, pp. 964-980.

Havranek, T. and Z. Irsova (2011), "Estimating Vertical Spillovers from FDI: Why Results Vary and What the True Effect Is", Journal of International Economics, Vol. 85, No. 2, pp. 234-244. 
Henrekson, M. and D. Johansson (2008), "Gazelles as Job Creators - A Survey and Interpretation of the Evidence”, IFN Working Paper, No. 733, Research Institute of Industrial Economics, Stockholm.

Hopenhayn, H. and R. Rogerson (1993), “Job Turnover and Policy Evaluation: A General Equilibrium Analysis”, Journal of Political Economy, Vol. 101, No. 5, pp. 915-938.

Javorcik, B. S. (2008), “Can Survey Evidence Shed Light on Spillovers from Foreign Direct Investment?" World Bank Research Observer, Vol. 23, No. 8, pp. 139-159.

Koopman, R., W. Powers, Z. Wang, and S. Wei (2010), Give Credit where Credit is Due: Tracing Valueadded in Global Production Chains, NBER Working Papers, No. 16426, Cambridge, MA.

Marin, D., A. Lorentowicz and A. Raubold (2003), "Ownership, Capital or Outsourcing: What Drives German Investment in Eastern Europe?" in H. Herrmann and R. Lipsey (eds), Foreign Direct Investment in the Real and Financial Sector in Industrial Countries, Berlin, Springer-Verlag, pp. 147-163.

Montt, G. (2015), "The Causes and Consequences of Field-of-study Mismatch: An Analysis Using PIAAC", OECD Social, Employment and Migration Working Papers, No. 167, OECD Publishing, Paris. http://dx.doi.org/10.1787/5jrxm4dhv9r2-en

Moscoso-Boedo, H. and T. Mukoyama (2012), "Evaluating the Effects of Entry Regulations and Firing Costs on International Income Differences", Journal of Economic Growth, Vol. 17, No. 2, pp. 143170.

Münich, D., M. Srholec, M. Moritz and J. Schäffler (2014), "Mothers and Daughters: Heterogeneity of German Direct Investments in the Czech Republic", Prague Economic Papers, Vol. 1.

Neumark, D., B. Wall and J. Zhang (2008), "Do Small Businesses Create More Jobs? New Evidence for the United States from the National Establishment Time Series", IZA Discussion Paper, No. 3888, IZA, Bonn.

OECD (2015a), OECD Science, Technology and Industry Scoreboard 2015: Innovation for growth and society, OECD Publishing, Paris. http://dx.doi.org/10.1787/sti_scoreboard-2015-en

OECD (2015b), "Effective innovation policies", in OECD, The Innovation Imperative: Contributing to Productivity, Growth and Well-Being, OECD Publishing, Paris. http://dx.doi.org/10.1787/9789264239814-8-en

OECD (2015c), Entrepreneurship at a Glance 2015, OECD Publishing, Paris. http://dx.doi.org/10.1787/entrepreneur_aag-2015-en

OECD (2015d), Employment Outlook 2015, OECD Publishing, Paris. http://dx.doi.org/10.1787/empl_outlook-2015-en

OECD (2015e), Financing SMEs and Entrepreneurs 2015: An OECD Scoreboard, OECD Publishing, Paris. http://dx.doi.org/10.1787/fin_sme_ent-2015-en

OECD (2015f), Taxation of SMEs in OECD and G20 Countries, OECD Tax Policy Studies, No. 23, OECD Publishing, Paris. http://dx.doi.org/10.1787/9789264243507-en 
OECD/WTO (2016), "Trade in Value Added", OECD-WTO: Statistics on Trade in Value Added (database). http://dx.doi.org/10.1787/data-00648-en

OECD (2014a), "Intelligent Demand: Policy Rationale, Design and Potential Benefits", OECD Science, Technology and Industry Policy Papers, No. 13, OECD Publishing, Paris http://dx.doi.org/10.1787/5jz8p4rk3944-en

OECD (2014b), OECD Economic Surveys: Czech Republic 2014, OECD Publishing, Paris. http://dx.doi.org/10.1787/eco_surveys-cze-2014-en

OECD (2013), Skills Outlook 2013: First Results from the Survey of Adult Skills, OECD Publishing, Paris. http://dx.doi.org/10.1787/9789264204256-en.

OECD (2010a), SMEs, Entrepreneurship and Innovation, OECD Publishing, Paris. http://dx.doi.org/10.1787/9789264080355-en

OECD (2010b), "Further advancing pro-growth tax and benefit reform", in OECD Economic Surveys: Czech Republic 2010, OECD Publishing, Paris. http://dx.doi.org/10.1787/eco_surveys-cze-2010-5en

Ollivaud, P. and D. Turner (2014), "The Effect of the Global Financial Crisis on OECD Potential Output", OECD Economics Department Working Papers, No. 1166, OECD Publishing, Paris. http://dx.doi.org/10.1787/5jxwt18h75bw-en

Olsen, K. B. (2006), "Productivity Impacts of Offshoring and Outsourcing: A Review”, OECD Science, Technology and Industry Working Papers, No. 2006/01, OECD Publishing, Paris. http://dx.doi.org/10.1787/685237388034

Rodrik, D. (2008), "Normalizing Industrial Policy", Commission on Growth and Development Working Paper, No. 3, World Bank.

Schworer, T. (2013), "Offshoring, domestic outsourcing and productivity: evidence for a number of European countries", Review of World Economics, No. 149, pp. 131-149.

Stancik, J. (2007), “Horizontal and Vertical FDI Spillovers,” CERGE-EI Working Papers, No. 340.

Wilson, K. E. (2015), "Policy Lessons from Financing Innovative Firms", OECD Science, Technology and Industry Policy Papers, No. 24, OECD Publishing, Paris. http://dx.doi.org/10.1787/5js03z8zrh9p-en 


\section{APPENDIX}

72. This appendix sets out additional analysis relating to two factors affecting labour productivity: (i) developments in labour supply and (ii) developments in the capital stock. The third section analyses the contribution of sectoral developments to overall productivity growth.

\section{Developments in labour supply}

73. As highlighted in OECD (2016a), a shortfall in labour productivity has developed as employment has grown but output remains well below its pre-crisis trend level. The increase in employment occurred in a context of an expanding labour supply (Figure A.1). Since 2009, the population aged 15-64 years has been shrinking, partly due to ageing and declining inward migration. However, participation has increased markedly, in particular among individuals aged between 50 and 64, offsetting demographic shifts.

\section{Figure A.1. Labour supply has expanded}

A. Labour force participation rates have risen ... Participation rates, per cent ${ }^{1}$

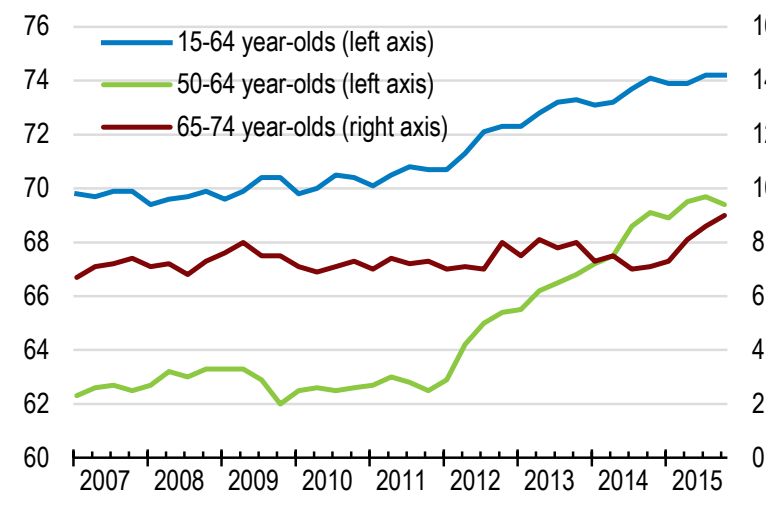

C. The working-age population has decreased ...

Population aged between 15 and 64 years, millions

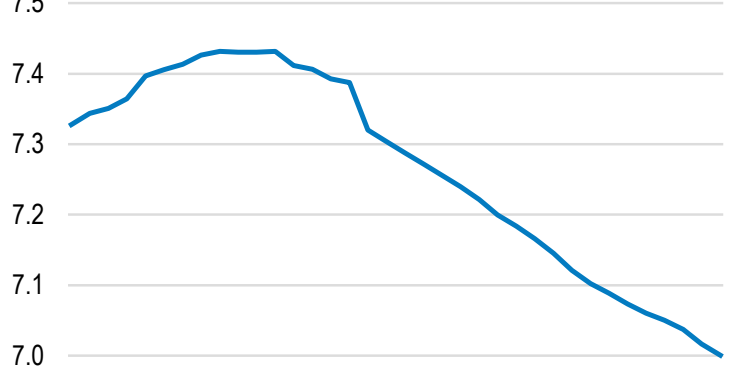

6.9

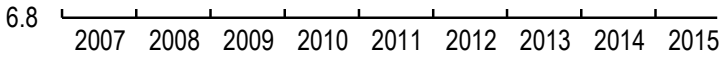

B. ... Offsetting demographic shifts

Participation rates, per cent ${ }^{1}$
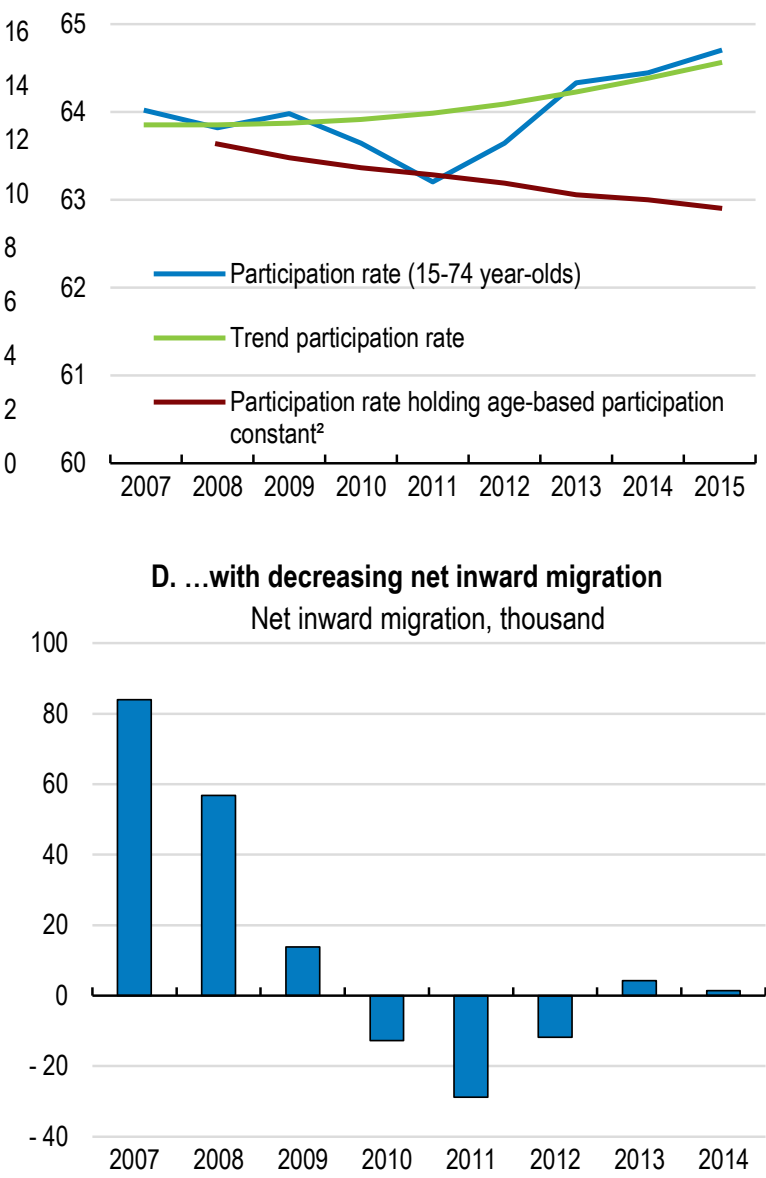

1. As a percentage of the age-cohort population.

2. The impact of demographic shifts on the participation rate is based on the assumption that participation rates for each age group and gender are held unchanged at their values in Q1 2007, while population shares vary.

Source: Eurostat and calculations based on OECD Economic Outlook database. 
74. Job creation in recent years has been mostly in high-skilled occupations (Figure A.2, Panel A). However, a lot of self-employment was created in 2011-12 as economic activity slowed and dependent employment contracted (Figure A.2, Panel B). These workers seem to have been absorbed into dependent employment more recently. As discussed above and in OECD (2016a), self-employment in the Czech Republic is high, representing 16\% of total employment, and above the European Union average (Figure A.3, Panel A). As is the case in most countries, self-employment is concentrated among older workers and this share has risen since the crisis (OECD, 2015c, Figure A.3, Panel B). But in the Czech Republic the incidence of self-employment is higher in younger age cohorts than in other countries.

\section{Figure A.2. Job creation has been in high-skilled occupations}

Cumulative contributions to the change in total employment since Q1 $2010^{1}$, thousand
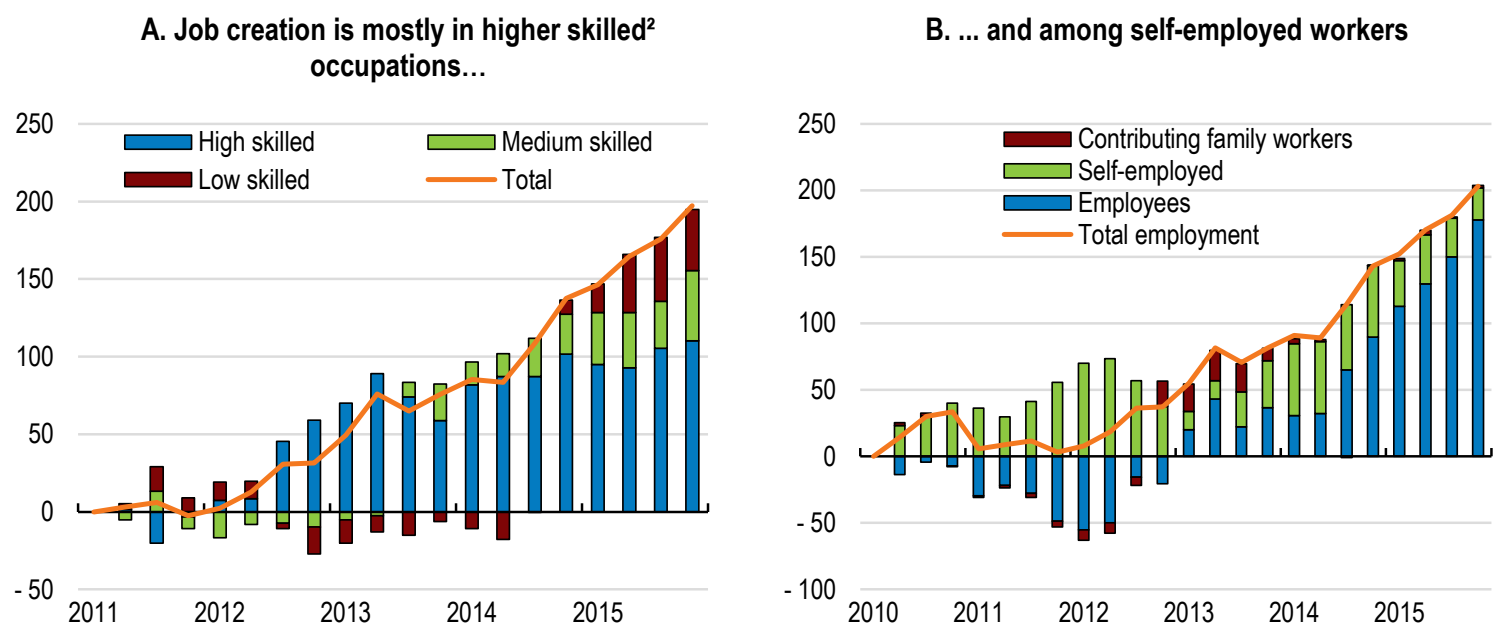

1. Panel A begins in 2011 Q1 due to a series break in the occupation definitions.

2. Skill intensity of occupations is defined according to major groups of the International Standard Classification of Occupations 2008

Source: OECD calculations based on Eurostat data. 
Figure A.3. Self-employment is high compared to other OECD countries

\section{A. The share of own-account workers is high}

Per cent of total employment (15-64 year-olds), 2015

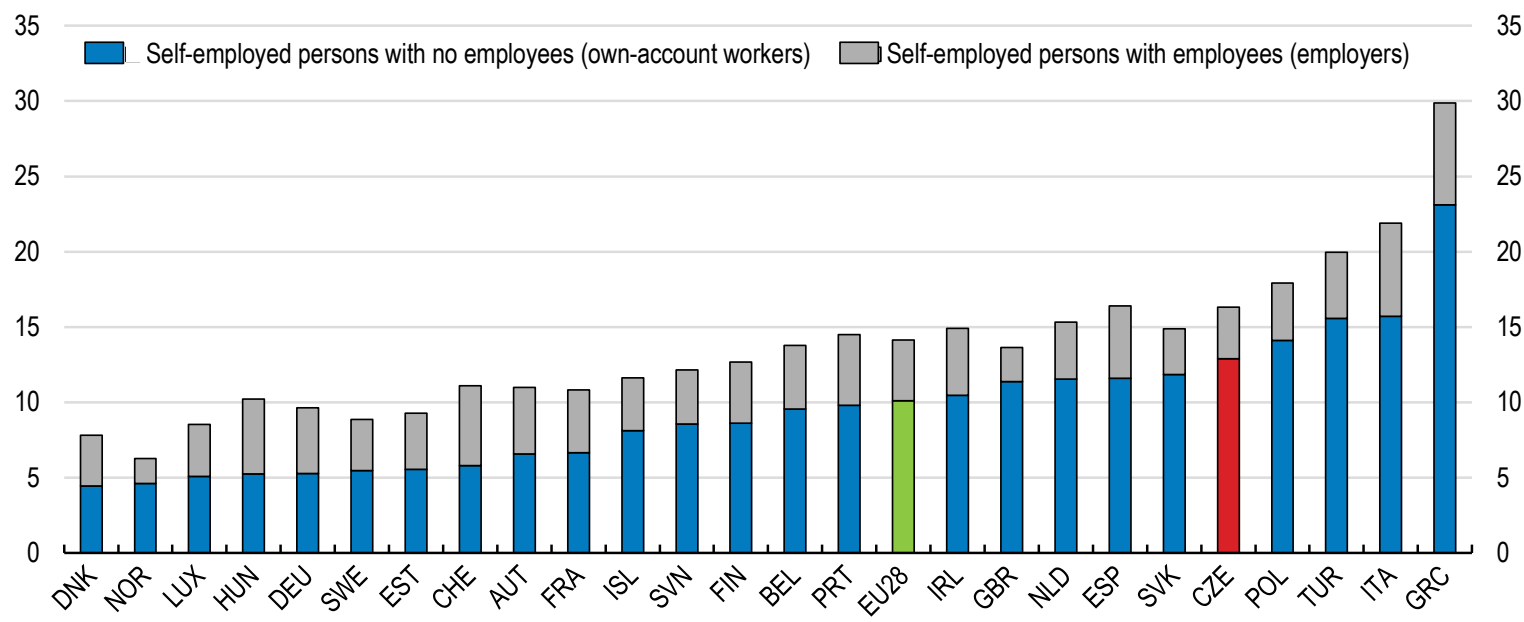

B. The incidence of self-employment is rising with age

Share of self-employed with no employees to total employment by age group, per cent, 2015

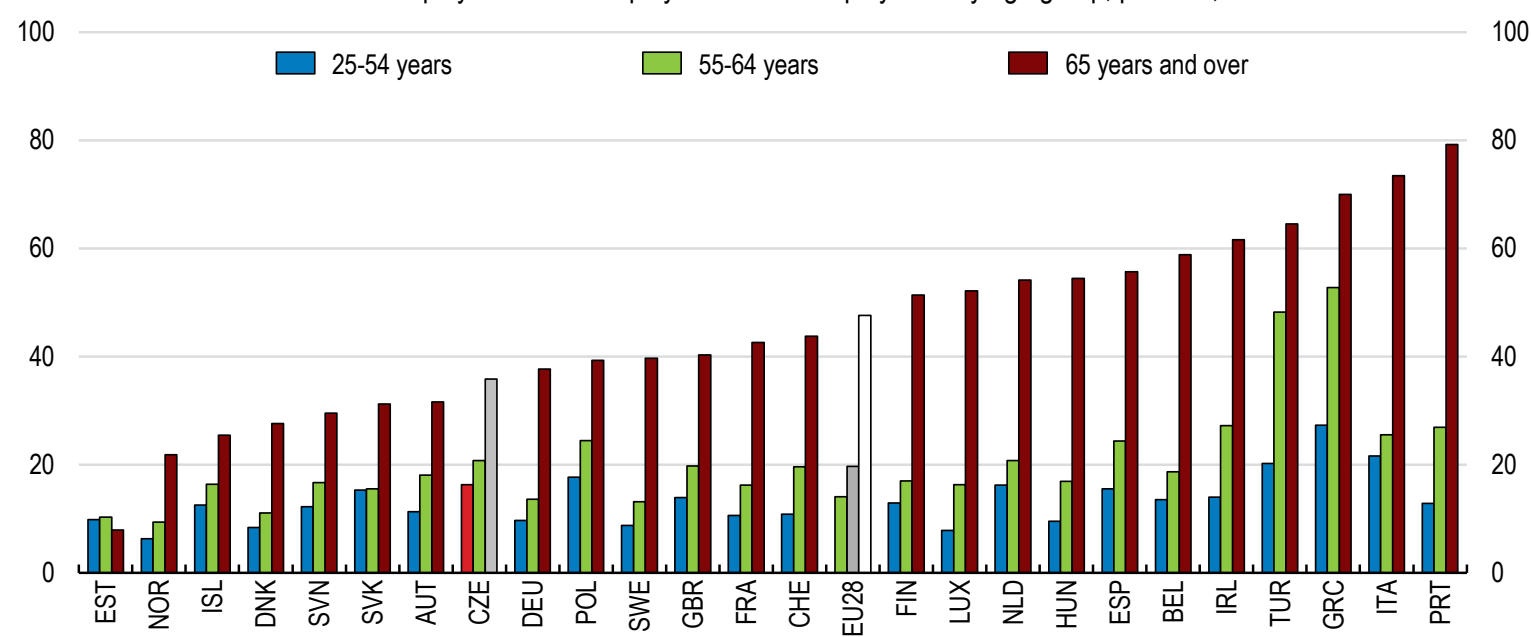

Source: Eurostat.

\section{Investment and capital accumulation has receded since the crisis}

75. As discussed above, the lacklustre economic performance is partly explained by developments in business investment and capital accumulation, which lost steam after the start of the crisis. The slower capital accumulation is explained partly by a decline in the investment rate though the Czech investment rate remains among the highest in the OECD (Figure A.4, Panel A). With large estimates of depreciation (Figure A.4, Panel B), the net additions to the capital stock have been small (see Figure 6). The increase in intangible investment has been strong, though it is growing from a low level (Figure A.4, Panel C). 
Figure A.4. Capital intensity in the Czech Republic is mixed

Average annual investment ratio, in nominal terms, in per cent of GDP

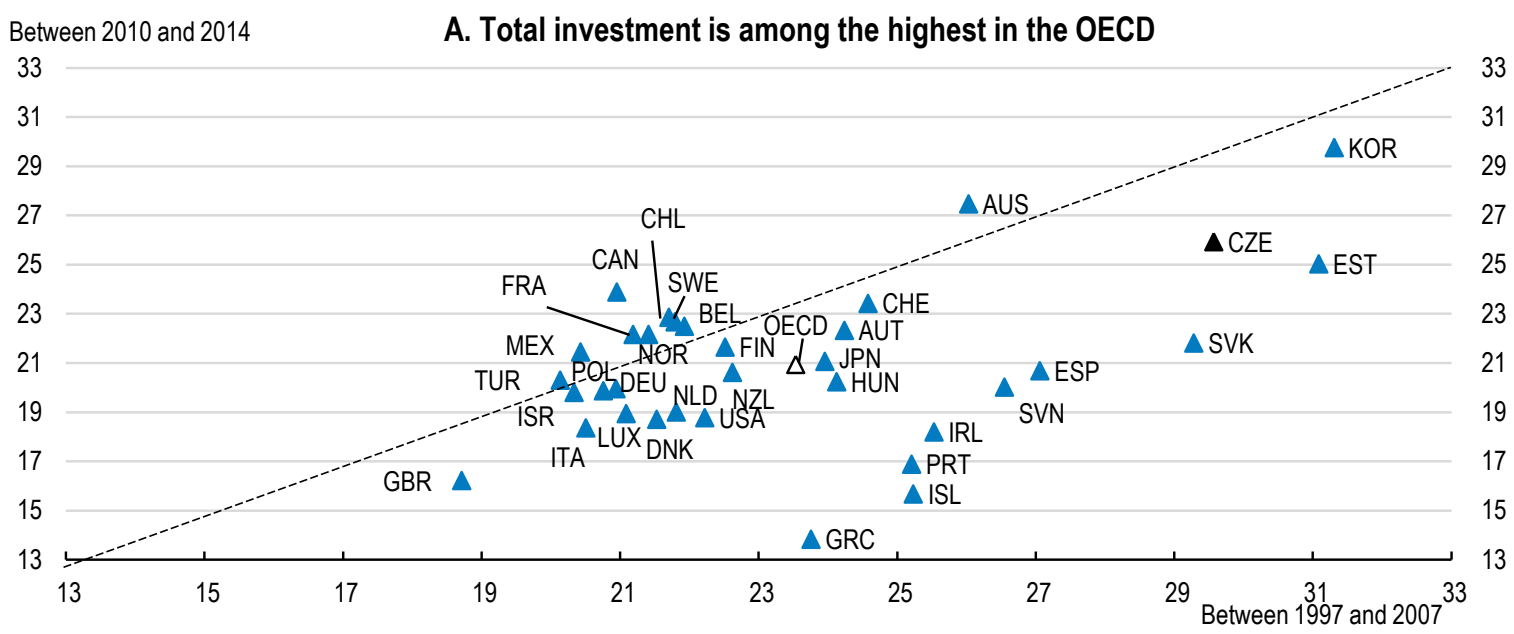

Between 2010 and 2014

B. Consumption of fixed capital is very high
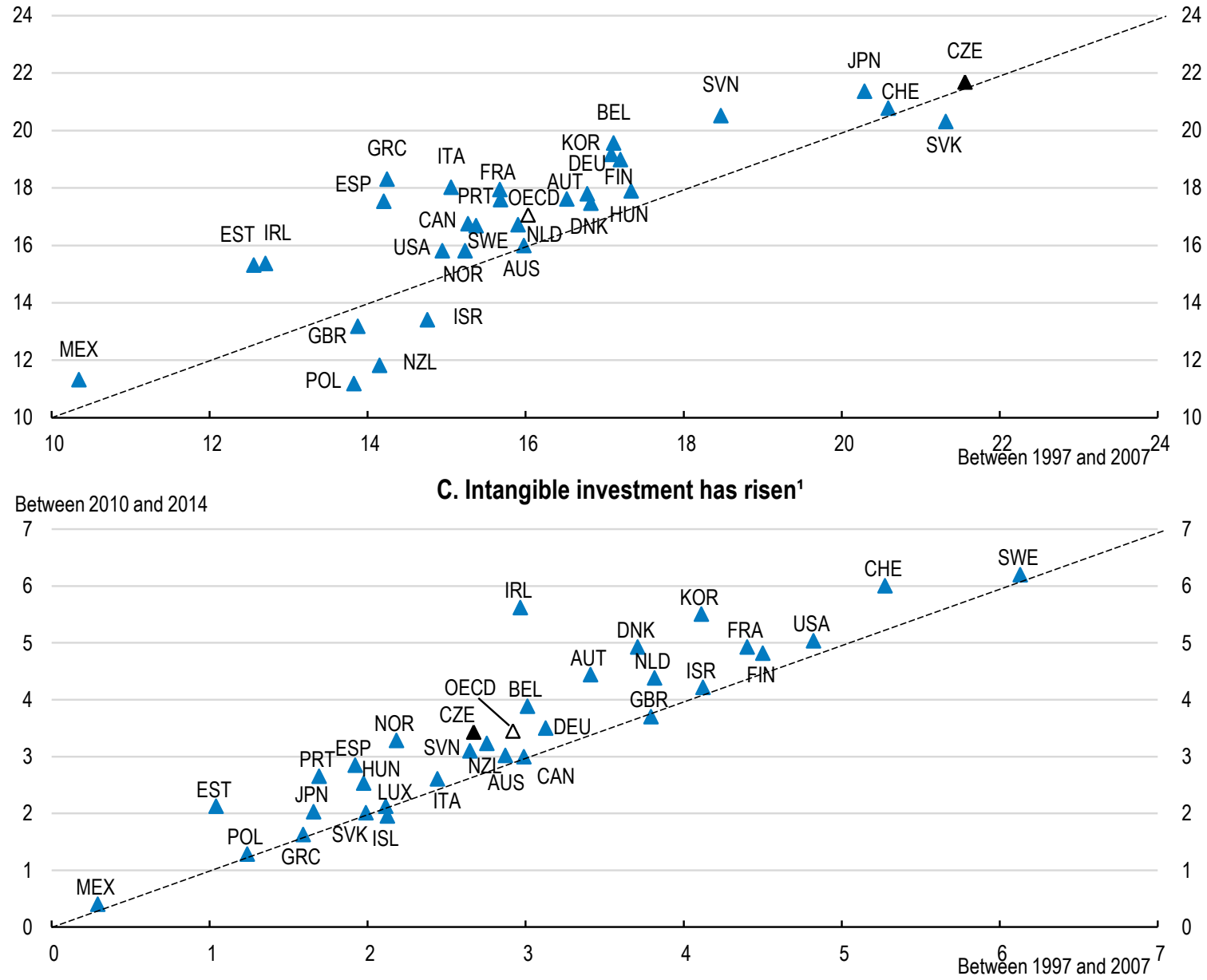

Note: The OECD average is an unweighted arithmetic average of the data shown.

1. Intangible investment refers to intellectual property products that include computer software and databases as well as research and development. Data for Mexico begin in 2003.

Source: OECD Economic Outlook database; OECD National Accounts database. 


\section{The contribution of sectoral productivity to the evolution of total productivity}

76. The economy-wide rate of productivity growth is also affected by sectoral developments. As shown in Figure A.5, Panel A the compositional shift of the economy, in particular from (non-financial) services to manufacturing, has increased since the crisis with manufacturing now representing $25 \%$ of total value added. However, while the share of manufacturing employment in total employment has been relatively stable, the share of non-financial services employment has stalled since the crisis, following a steep increase in the decade before (Figure A.5, Panel B).

\section{Figure A.5. The importance of services has been rising in the Czech Republic}

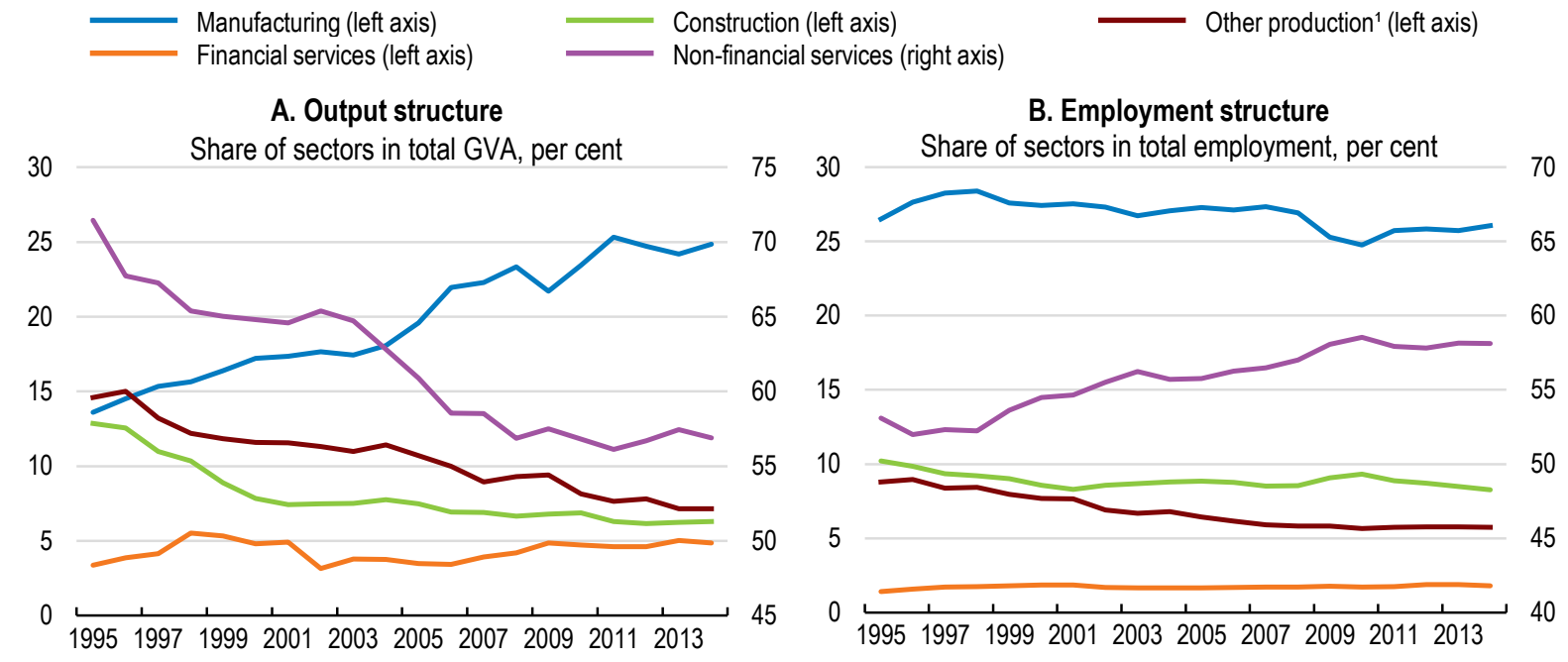

1. Other production refers to agriculture, forestry and fishing (Section A), mining and quarrying (Section B), electricity, gas, steam and air conditioning supply (Section D) and water supply, sewerage, waste management and remediation activities (Section E).

Source: OECD Annual National Accounts database.

77. Decomposition of labour productivity by sector shows that labour productivity growth fell in all sectors except financial and insurance activities in the period 2007-14 compared with 2001-07 (Figure 5). The fall in productivity growth between the two periods was also large compared to other countries in both business services excluding real estate and manufacturing (Figure A.6, panels A and B). Within the business services sector, the fall in the sector comprising distributive trade, transportation and accommodation \& food services was the third-largest after Estonia and Latvia (Figure A.6, panel C). 
Figure A.6. Change in average labour productivity growth by sector

Difference in growth from 2007-14 compared to 2001-07, percentage points

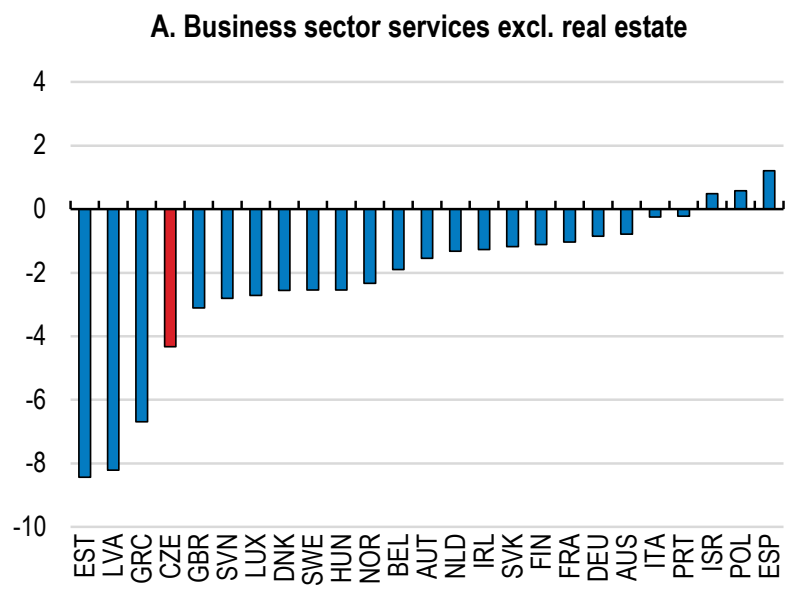

C. Distributive trade, transportation, accomodation and food services

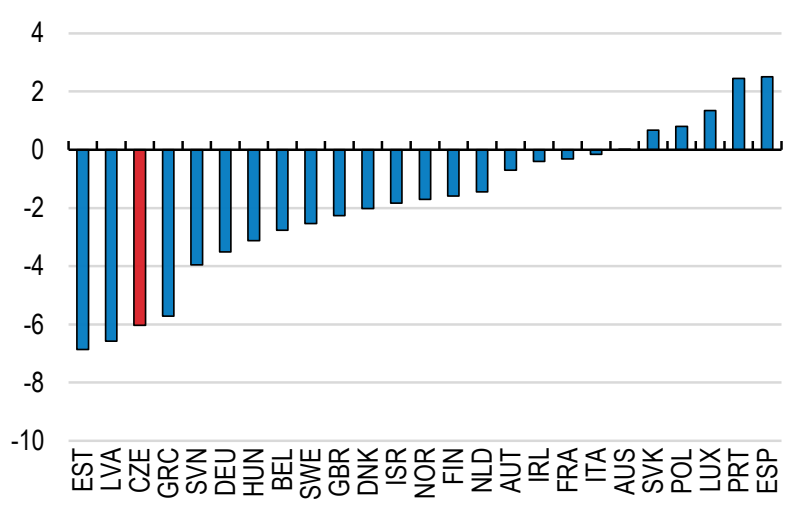

E. Financial and insurance activities

5

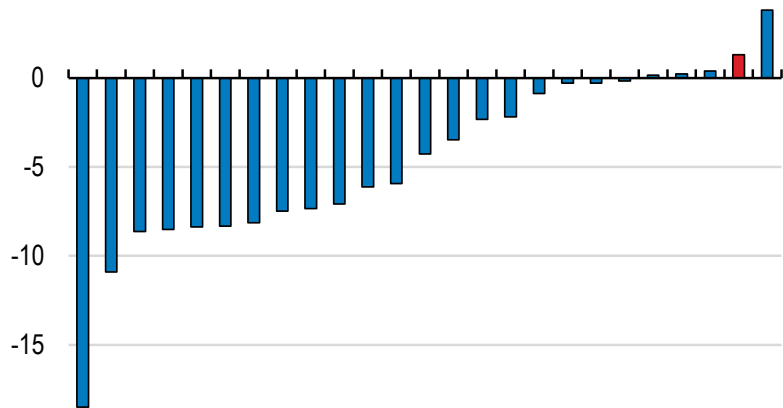

$-20$

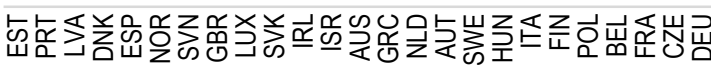

B. Manufacturing
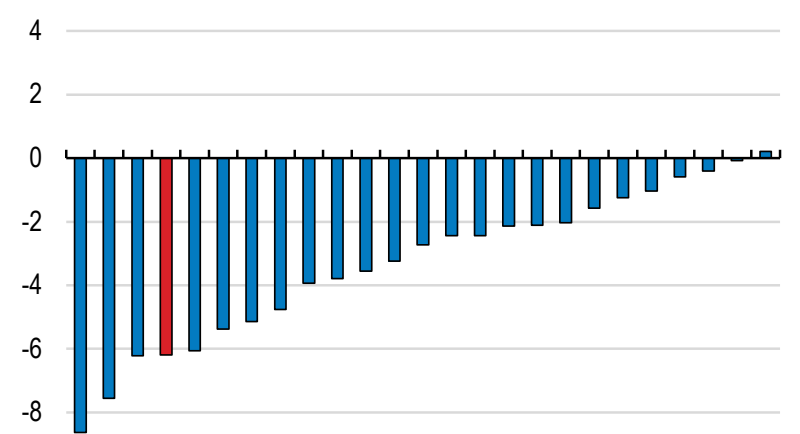

$-10$

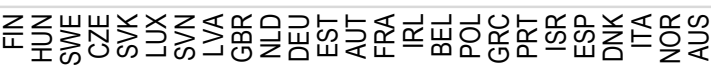

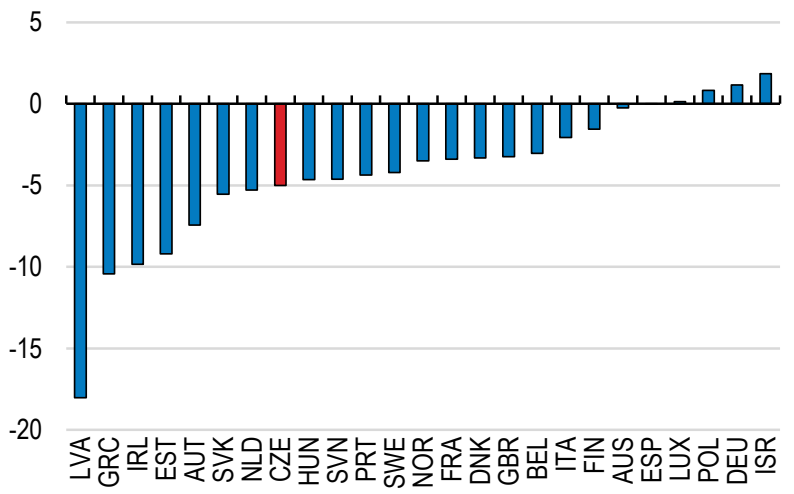

F. Professional, scientific and support activities

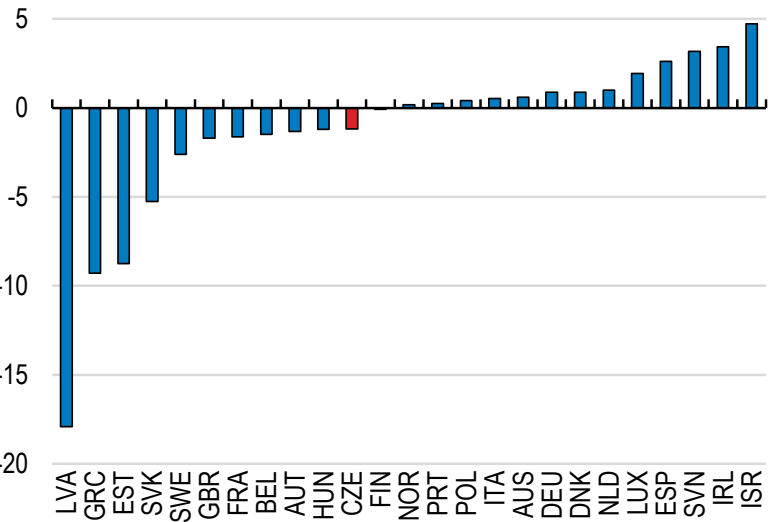

Note: "Business sector services" comprises the industries shown in Panels D to F.

Source: OECD Productivity Database. 
78. A shift-share analysis shows that the sectoral reallocation of resources, in particular of employment, has played a small role in aggregate developments in labour productivity. The main driver of aggregate productivity growth has been within-sector labour productivity, through reallocation of labour between firms or changes in the productivity of individuals (Figure A.7). Indeed, the gains in the service sector employment share (6 percentage points in 15 years (Figure A.5, Panel B)) have been mostly to the detriment of construction and other production sectors.

Figure A.7. Productivity gains within each sector have driven aggregate labour productivity growth

Contribution to aggregate labour productivity growth, percentage points ${ }^{1}$

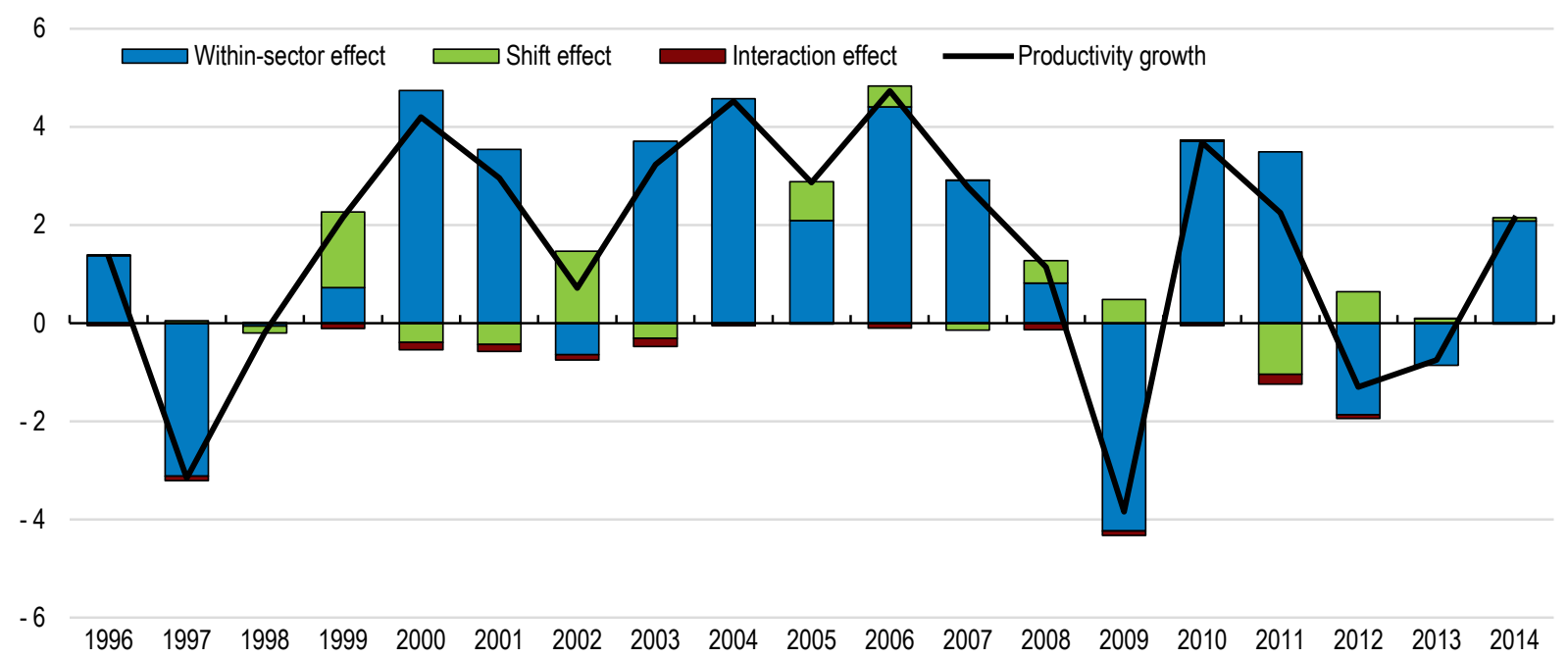

1. "Within-sector effect" is defined as contribution to aggregate productivity growth within each sector. "Shift effect" is defined as contribution to aggregate productivity growth of labour reallocation between sectors with different productivity levels. "Interaction effect" is defined as contribution to aggregate productivity growth of labour reallocation between sectors with different productivity growth rates. Results of shift-share analysis for 1-digit sectors of International Standard Industrial Classification Revision 4.

Source: Calculations based on data from OECD Annual National Accounts database. 